\title{
Evaluation of tree growth and chemical, physical and biochemical soil properties of two reclaimed surface mines in West Virginia
}

\author{
Calene B. Thomas \\ West Virginia University
}

Follow this and additional works at: https://researchrepository.wvu.edu/etd

\section{Recommended Citation}

Thomas, Calene B., "Evaluation of tree growth and chemical, physical and biochemical soil properties of two reclaimed surface mines in West Virginia" (2012). Graduate Theses, Dissertations, and Problem Reports. 2284.

https://researchrepository.wvu.edu/etd/2284

This Thesis is protected by copyright and/or related rights. It has been brought to you by the The Research Repository @ WVU with permission from the rights-holder(s). You are free to use this Thesis in any way that is permitted by the copyright and related rights legislation that applies to your use. For other uses you must obtain permission from the rights-holder(s) directly, unless additional rights are indicated by a Creative Commons license in the record and/ or on the work itself. This Thesis has been accepted for inclusion in WVU Graduate Theses, Dissertations, and Problem Reports collection by an authorized administrator of The Research Repository @ WVU. For more information, please contact researchrepository@mail.wvu.edu. 


\title{
EVALUATION OF TREE GROWTH AND CHEMICAL, PHYSICAL AND BIOCHEMICAL SOIL PROPERTIES OF TWO RECLAIMED SURFACE MINES IN WEST VIRGINIA
}

\author{
Calene B. Thomas \\ Thesis submitted to the College of Agriculture, Natural Resources and Design \\ at West Virginia University \\ in partial fulfillment for the requirements \\ for the degree of \\ Master of Science \\ In \\ Plant and Soil Sciences
}

\author{
Committee: \\ Jeffrey G. Skousen, Ph.D., Chair \\ Alan J. Sexstone. Ph.D. \\ Ray R. Hicks, Jr., Ph.D. \\ Division of Plant and Soil Sciences \\ West Virginia University \\ Morgantown, WV
}

2012

Keywords: Mine Land Reclamation, Forestry Reclamation Approach, Appalachian Regional Reforestation Initiative, compaction, sandstone overburden, bark mulch, soil biochemical properties. 


\section{ABSTRACT}

\section{Evaluation of Tree Growth and Chemical, Physical and Biochemical Soil Properties of Two Reclaimed Surface Mines in West Virginia}

\section{Calene B. Thomas}

Advancements in technology and coal mining methods have accelerated the disturbance of valuable contiguous deciduous forests in the Appalachian region. In many instances, mountaintop mining has converted large expanses of forested mountaintops to rolling pasture and hay land that have been left abandoned to revert to shrub land dominated by invasive nonnative species. Due to excessive soil compaction and heavy herbaceous cover, natural plant community succession from planted grasslands to hardwood forests is slow. Recently, efforts are being made to re-establish hardwood forests on mined land through careful spoil and amendment selection, and placement and planting of appropriate herbaceous and tree species. In order to evaluate tree growth and survival on selected spoils with various amendments, two study areas were established on two mountaintop mines in West Virginia. The oldest study area is Catenary Coal's Samples Mine in Kanawha County, WV, where three 2.8-hectare demonstration plots were established in 2005. Two plots were comprised of oxidized (brown) sandstone and one of un-oxidized (gray) sandstone. Half of all plots were "tracked" in to produce a smooth compacted surface. Care was taken to leave the other half of the plot relatively uncompact, producing a rough uneven surface. The study area was planted with a variety of hardwood tree species, mainly oaks, sugar maple and black cherry, on 2.4-m centers. Soil chemical properties and tree volume index and survival were evaluated for seven years. Substrate type had a significant effect on tree volume index with brown sandstone consistently outperforming gray sandstone. Of the eleven tree species planted, dogwood, black cherry, and red and white oak gave the highest growth index. Compaction did not have a significant effect on tree volume index. In 2011, $\mathrm{pH}$, fines, Fe, P, and $\mathrm{Zn}$ where all significantly higher in gray sandstone. Differences were found for electrical conductivity and all extractable elements between 2005 and 2011. Aluminum was significantly lower in brown sandstone. Compaction had no effect on soil properties.

The second study area was a 3-ha demonstration plot created at Arch Coal's Birch River mine near Cowen, WV. The plot is comprised of two exclusive areas of brown and gray sandstone substrates. Approximately one third of each was amended with bark mulch and/or hydroseeded with fertilizer and low growing non-competitive herbaceous species, creating a total of eight treatments. The study area was planted with a variety of hardwood tree species, mainly oaks, sugar maple and black cherry, on 2.4-m centers. Soil chemical properties and tree survival and growth were evaluated for four years beginning in 2007. Using a model approach and Akaike's Information Criterion (AIC) to analyze tree and soil data, sandstone type and mulch had the highest empirical support for influencing tree volume index and soil chemical properties. No strong empirical support was found for any of our pre-selected models for predicting or inferring tree survival. Like the Catenary study, tree volume index on brown sandstone at Birch River was consistently higher than gray. After four years, hydroseeding had no effect on tree volume index, survival or soil chemical properties. Mulch application had the ability to improve tree growth in both sandstone types and had a strong influence on soil chemical properties. 
In addition, soil organic carbon (SOC), microbial biomass carbon (MBC), total combustible nitrogen (TCN), potentially mineralizable nitrogen (PMN) was also measured for soil samples of the Birch River study area. Substrate had no effect on these properties. Hydroseed application had a significant effect on MBC and TMN. Both of these biochemical properties were higher in the hydroseed application treatment. 


\section{Acknowledgments}

First and foremost, I would like to thank my advisor, Jeff Skousen, for providing me with the opportunity to engage in research and education related to mine land reclamation. Without his support none of this would have been possible. He has provided me much encouragement, reassurance, and assistance throughout my graduate school experience. He offered much needed criticisms and advice that will continue to help me with future endeavors. I would like to thanks my committee members, Alan Sexstone and Ray Hick for their guidance and assistance. They have dedicated much time and many resources to my research. They were crucial to the development of my research and thesis. I would like to thank Dr. George Merovich for helping me through my statistical analysis. Although he had no obligation to me, he met with me several times and spent many hours helping me understand and develop an appropriate statistical analysis for my project. All faculty and staff of the Plant and Soil Science Division have been more than helpful throughout my research and coursework at West Virginia University.

I would like to thank Joan Wright for processing samples and for instruction on lab equipment. A special thanks to Lindsey Bishop. Without her dedicated help in the field and the lab for the last two years, the seemingly impossible task of data collection would have been overwhelming.

There are several graduate students I feel deserve to be mentioned by name. Thank you, Greg Klinger for spending many long days in the lab troubleshooting our methods. The biochemical aspect of my research would have been very daunting and difficult without your help and collaboration. Mike Marra, thank you for helping me keep my sanity. I enjoyed our many pep talks. Curtis DeLong was especially helpful in the beginning of the process and again in the end providing instruction and advice for the lab, field and classroom. Others I would like to mention are Mike Harmon, Travis Keene and Donglin Huang. The camaraderie of all the plant and soil graduate students has made this a very fulfilling life experience.

Finally, I would like to thank Arch Coal, Inc. (specifically Keith O’Dell) WV DEP and OSM for their participation and cooperation in the research. 


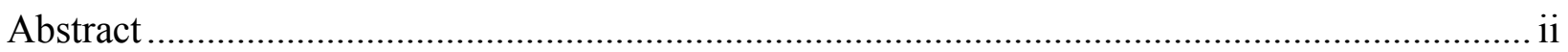

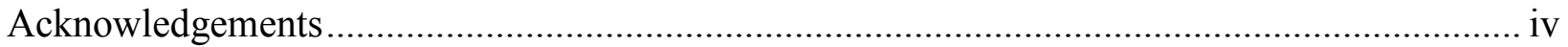

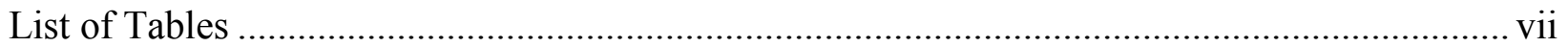

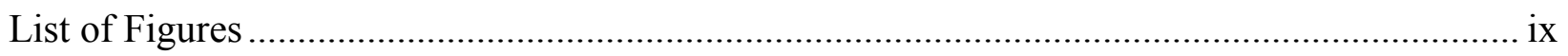

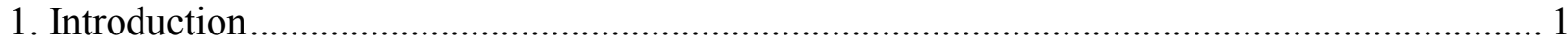

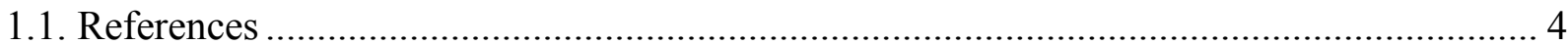

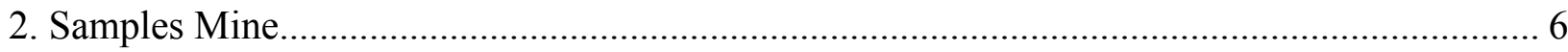

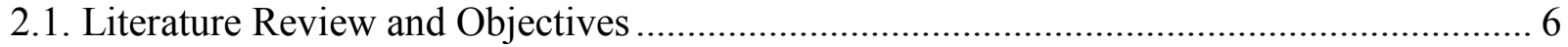

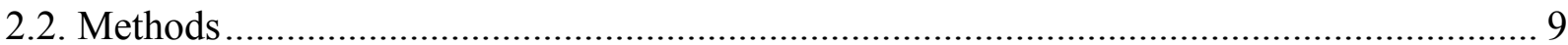

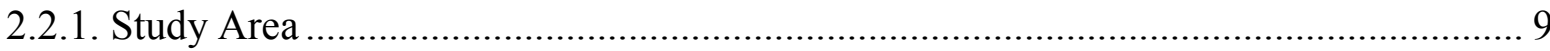

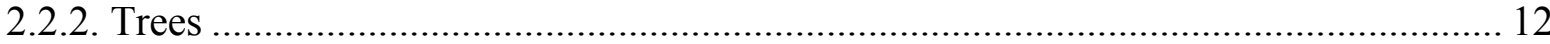

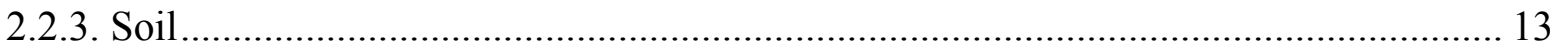

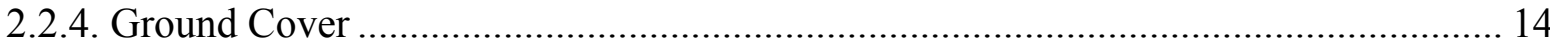

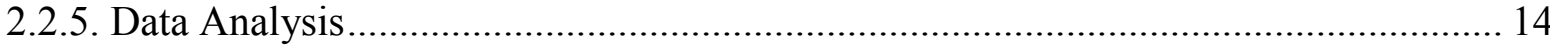

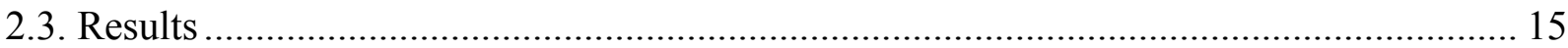

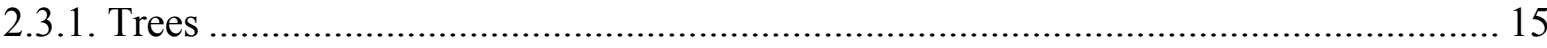

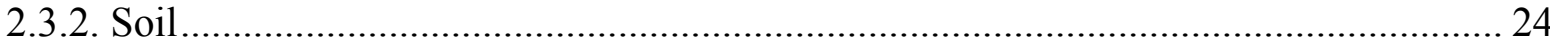

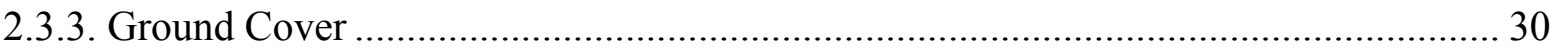

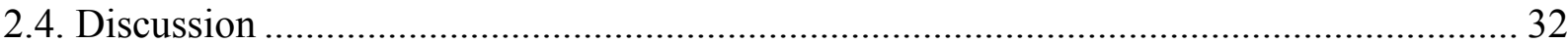

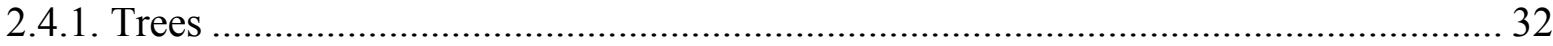

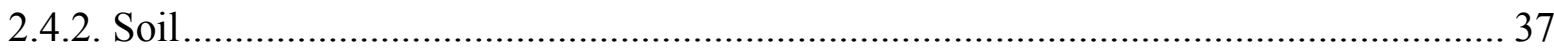

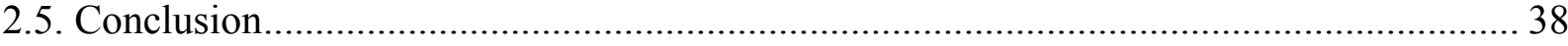

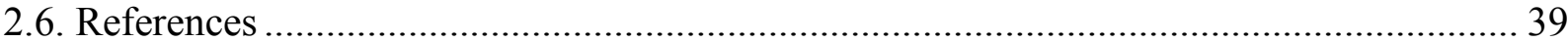

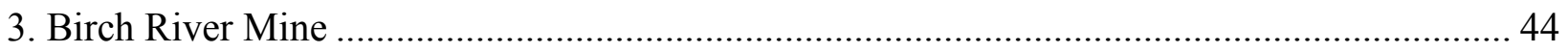

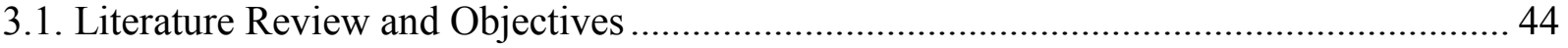

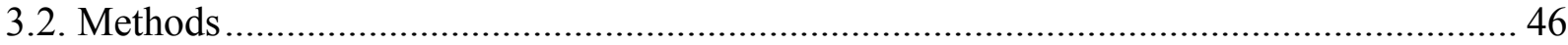

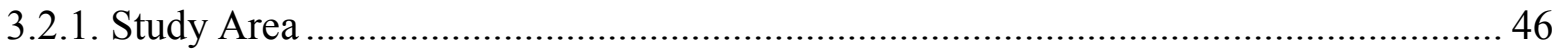

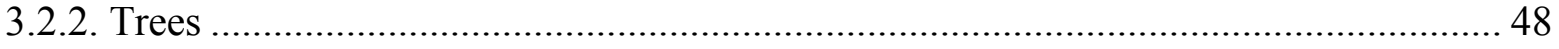




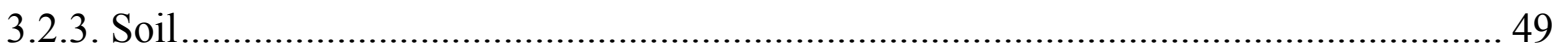

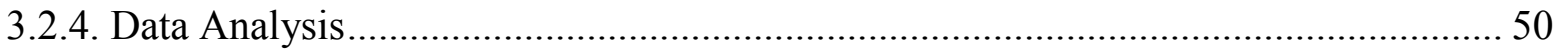

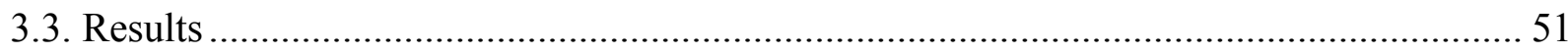

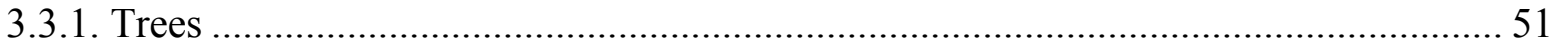

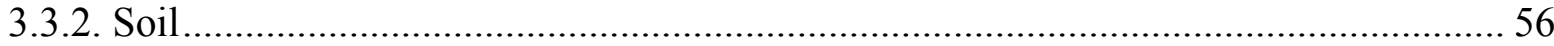

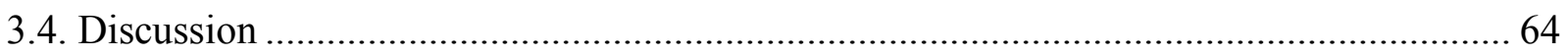

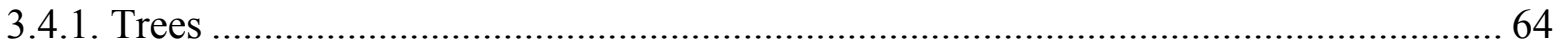

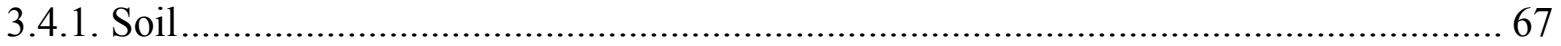

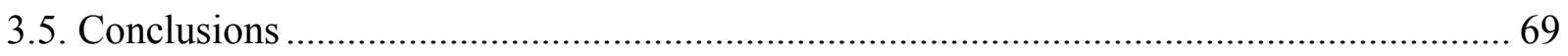

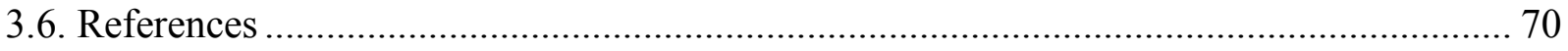

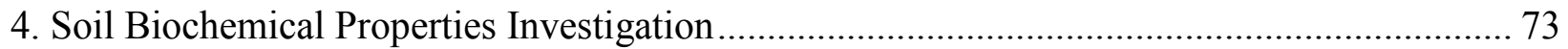

4.1. Literature Review and Objectives .............................................................................. 73

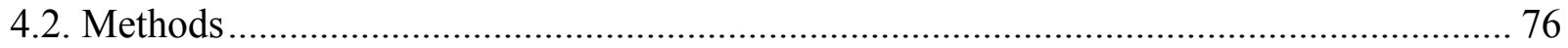

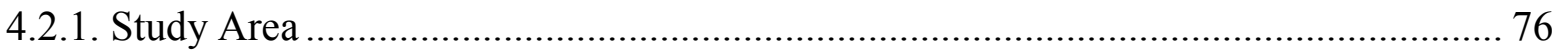

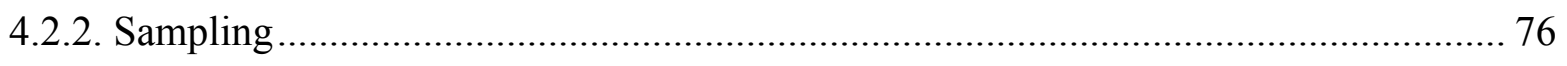

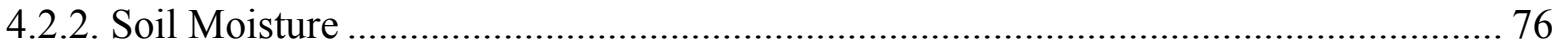

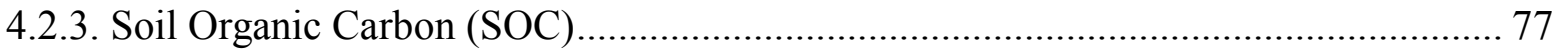

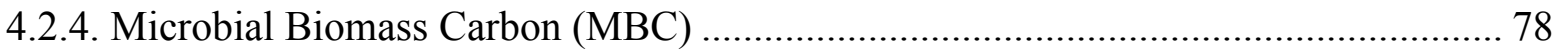

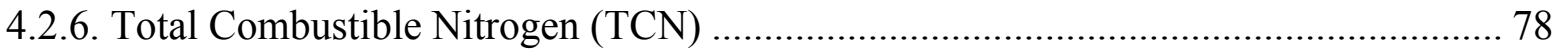

4.2.7. Potentially Mineralizable Nitrogen (PMN) ............................................................ 79

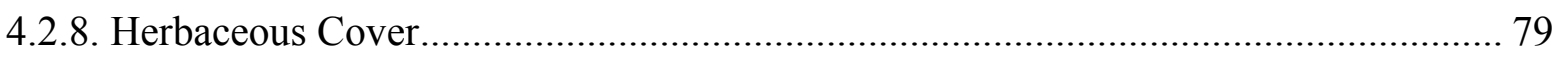

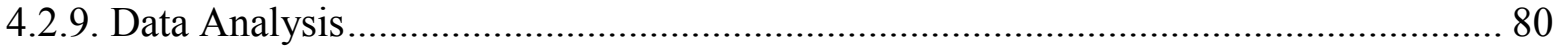

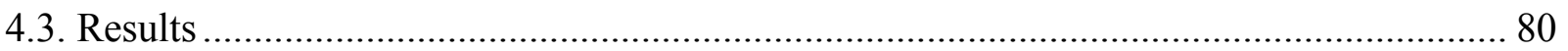

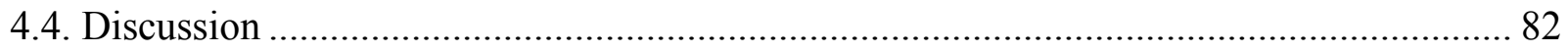

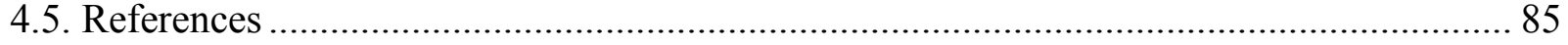


Table 2-1. Soil treatment combinations at Catenary Coal's Samples mine operation in Kanawha County, West Virginia. …………………………….................................................... 10 Table 2-2. Species and number of trees planted at Catenary Coal's Samples mine operation in Kanawha County, West Virginia. ............................................................................................ 12 Table 2-3. Species and rate of ground cover hydroseeded at Catenary Coal's Samples mine operation in Kanawha County, West Virginia............................................................................. 12 Table 2-4. Main treatment effects for volume index and survival after seven growing seasons in four soil treatments at Catenary Coal's Samples mine in Kanawha County, WV. ...................... 16 Table 2-5. Distribution of tree species in 2011 after seven growing seasons in four soil treatments at Catenary Coal's Samples mine in Kanawha County, WV ........................................................ 18 Table 2-6. Mean tree volume index of tree species in 2011 after seven growing seasons in four soil treatments at Catenary Coal's Samples mine in Kanawha County, WV ............................... 19 Table 2-7. Main treatment effects for volume index and survival of Red oak after seven growing seasons in four soil treatments at Catenary Coal's Samples mine in Kanawha County, WV. ..... 20 Table 2-8. Soil treatment combinations at Catenary Coal's Samples mine operation in Kanawha

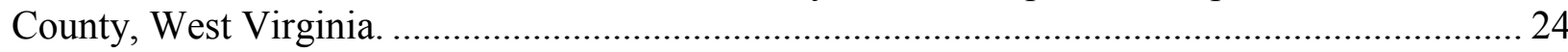
Table 2-9. Soil properties of samples from four soil treatments at Catenary Coal's Samples mine in Kanawha County, WV.** 25 Table 2-10. Soil properties of samples from four soil treatments at Catenary Coal's Samples mine in Kanawha County, WV. ${ }^{* *}$........................................................................................ 26 Table 2-11. Mean ground cover on four soil treatments in 2011 at Catenary Coal's Samples mine in Kanawha County, WV. 31

Table 2-12. Mean tree volume index for 2005, 2007, 2009, and 2011 growing seasons in four soil treatments at Catenary Coal's Samples mine in Kanawha, WV.* 34 Table 3-1. Species and number of trees planted at the Birch River Operation in Webster County, WV 47

Table 3-2. Species and rate of ground cover hydroseeded at the Birch River Operation in

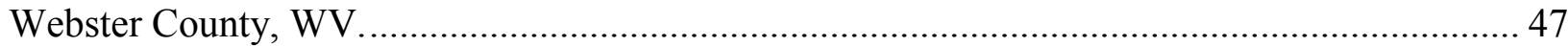
Table 3-3. Soil treatment combinations at the Birch River Operation in Webster County, WV.. 48 Table 3-4. Model ranking using AIC for volume index of trees planted at the Birch River Operation in Webster County, WV ........................................................................................ 54 Table 3-5. Mean volume index for eleven species of trees after four growing seasons in eight soil treatment combinations at the Birch River Operation in Webster County, WV* ....................... 56 Table 3-6. Model ranking using AIC for survival of trees planted at the Birch River Operation in

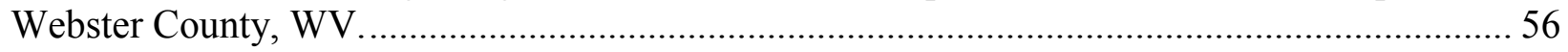
Table 3-7. PCA results for first 3 PCs of 2011 soil properties sampled at the Birch River Operation in Webster County, WV. 58 Table 3-8. Model ranking using AIC for PC soil analyses with treatments at the Birch River Operation in Webster County, WV. 60 Table 3-9. 2008-2011 soil properties in eight soil treatment combinations at the Birch River Operation in Webster County, WV. 60 
Table 3-10. 2008-2011 soil properties in eight soil treatment combinations at the Birch River Operation in Webster County, WV*....

Table 3-11. Number and distribution of eleven species of trees after four growing seasons in eight soil treatment combinations at the Birch River Operation in Webster County, WV............ 66 Table 4-1. Mean microbial biomass carbon (MBC), potentially mineralizable nitrogen (PMN) and percent herbaceous cover $(\mathrm{HC})$ for mine soils after five growing seasons at the Birch River Operation in Webster County, WV

Table 4-2. Carbon and Nitrogen fractions in mine soil samples after five growing seasons at the Birch River Operation in Webster County, WV.

Table 4-3. MBC:Total Carbon (TC) and PMN:TCN ratios expressed as a percentage after five growing seasons at the Birch River Operation in Webster County, WV. 


\section{List of Figures}

Figure

Page No.

Figure 2-1. Treatment layout at Catenary Coal's Samples mine operation in Kanawha County,

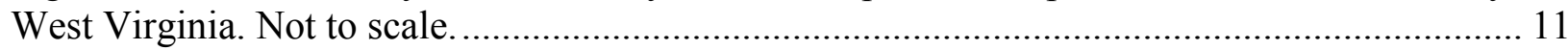

Figure 2-2. Boxplot of tree volume index of all tree species for four soil treatments at Catenary Coal's Samples mine in Kanawha County, WV.

Figure 2-3. Boxplot of Sugar maple volume index for four soil treatments at Catenary Coal's Samples mine in Kanawha County, WV.

Figure 2-4. Boxplot of Red oak volume index for four soil treatments at Catenary Coal's

Samples mine in Kanawha County, WV. 21

Figure 2-5. Boxplot of White ash volume index for four soil treatments at Catenary Coal's Samples mine in Kanawha County, WV. 22

Figure 2-6. Boxplot of White oak volume index in for four soil treatments at Catenary Coal's

Samples mine in Kanawha County, WV. 22

Figure 2-7. Boxplot of White pine volume index in four soil treatments at Catenary Coal's Samples mine in Kanawha County, WV. 23

Figure 2-8. Boxplot of Tulip poplar volume index for four soil treatments at Catenary Coal's Samples mine in Kanawha County, WV.

Figure 2-9. Boxplot of soil pH in soil samples of four soil treatments at Catenary Coal's Samples mine in Kanawha County, WV.

Figure 2-10. Boxplot of \% fines in soil samples of four soil treatments at Catenary Coal's Samples mine in Kanawha County, WV. 28

Figure 2-11. Boxplot of Al concentrations in soil samples of four soil treatments at Catenary Coal's Samples mine in Kanawha County, WV. 28

Figure 2-12. Boxplot of Fe concentrations in soil samples of four soil treatments at Catenary Coal's Samples mine in Kanawha County, WV.

Figure 2-13. Boxplot of $\mathrm{P}$ concentrations in soil samples of four soil treatments at Catenary Coal's Samples mine in Kanawha County, WV.

Figure 2-14. Boxplot of $\mathrm{Zn}$ concentrations in soil samples of four soil treatments at Catenary Coal's Samples mine in Kanawha County, WV.

Figure 2-15. Boxplot of total ground cover in 2011 on four soil treatments at Catenary Coal's Samples mine in Kanawha County, WV.

Figure 2-16. Boxplot of exposed soil and rock in 2011 on four soil treatments at Catenary Coal's Samples mine in Kanawha County, WV. 32

Figure 3-1. Simplified diagram of treatment layout at the Birch River Operation in Webster County, WV. Not to scale. 48

Figure 3-2. 2009-2011 box plots of tree volume indices for areas of brown (B) and gray (G) sandstone with (M) and without (NM) mulch application at the Birch River Operation in Webster County, WV. 55

Figure 3-3. PC1:PC2 biplot of 2011 soil properties sampled at the Birch River Operation in Webster County, WV. 58

Figure 3-4. PC1:PC2 biplots of 2008 to 2010 soil properties sampled at the Birch River Operation in Webster County, WV. 
Figure 3-5. 2011 box plots of $\mathrm{pH}, \mathrm{EC}$, and percentage fines from samples taken from areas of brown (B) and gray (G) sandstone with mulch (M) and without mulch application at the Birch River Operation in Webster County, WV.

Figure 3-6. Box plots of extractable elements from samples taken in 2011 from areas of brown (B) and gray (G) sandstone with mulch (M) and without mulch application at the Birch River Operation in Webster County, WV. 


\section{Introduction}

For over a century coal mining has been an important industry in West Virginia, creating jobs and generating revenue for the state and surrounding region. With advancements in technology and mining methods in recent decades, coal mining has accelerated the disturbance of the valuable contiguous forests in the Appalachian region (Townsend et al., 2009; Wickham et al., 2007). Mountaintop mining methods in many instances have converted large expanses of forested mountain tops to rolling pasture and hay lands. Touted for their economic potential, these pasture/hay lands have mostly remained unmanaged and have reverted to shrub land dominated by invasive non-native species (Torbert and Burger, 2000; Zipper et al., 2011). Due to excessive soil compaction and heavy herbaceous cover, natural plant community succession to hardwood forests is slow (Simmons et al, 2008). Invasive species, both shrubs and herbaceous plants, compete too fiercely for nutrients and available water (Burger et al., 2008; Skousen et al., 2006; Zipper et al., 2011). Combined with the harsh soil conditions, colonization and growth of trees is difficult.

In the last decade, the Office of Surface Mining (OSM) has encouraged coal operators and land owners to opt for forestry land uses in land reclamation and move away from pasture and hay land. Forested land could be an effective and beneficial land use producing valuable hardwood for timber and providing ecological services, such as increased water infiltration and watershed protection, wildlife habitat, and greater biodiversity (Byrd et al., 2002; Gorman et al., 2001; Larkin et al., 2008; Showalter et al., 2007; Zipper et al., 2011). Rapid tree regeneration and forest succession depends on soils with properties suited for forest reclamation. Therefore, reclamation specialists are interested in expediting this process of natural succession by 
manipulating the placement and selection of sandstone substrate to maximize tree growth (Zipper et al., 2011).

The Appalachian Regional Reforestation Initiative has adopted a forestry reclamation approach (FRA) that includes five factors that contribute to healthy tree growth on reclaimed mine sites (Burger et al., 2005; Zipper et al., 2011). These include (1) substrate selection, (2) substrate placement, (3) tree selection, (4) herbaceous vegetation selection and application rate, and (5) tree planting technique. Mulches, while not recognized by the FRA, could impart beneficial characteristics to the growth matrix and improve tree growth.

With the success of the FRA, reclamationists and researchers are continuing to become interested in enhancing ecosystem services on these restored forests in the Appalachia coalfields. Physical and chemical properties of mine soils and their relationship to herbaceous and tree growth are becoming better understood and can help determine which spoil materials are to be placed on the surface for reclamation to a specific post-mining land use. Judging the potential of these spoil materials for plant growth is heavily dependent on soil properties that support plant community development, diversity, and sustainability of vegetation. Although bond release is contingent on the latter, a move towards restoration would include the evaluation of how well these substrates support other ecosystem components such as microbial populations and communities. Microorganisms play an essential role in nutrient cycling, soil formation, organic matter turnover, and ultimately plant establishment and long-term stability of a site. Physical, chemical and biological soil quality indicators are important in considering the long-term vegetation stability and plant community sustainability, and could provide a more comprehensive evaluation of reclamation success. 
The objectives of the proposed study were to:

1. Evaluate tree survival and volume index on compacted and non-compacted substrate plots comprised of weathered brown sandstone and un-weathered gray sandstone at the Samples Mine in Kanawha County, West Virginia. Evaluate the same on weathered brown sandstone and un-weathered gray sandstone amended with bark mulch and hydroseed at the Birch River Mine in Webster County, West Virginia

2. Evaluate the soil chemical and physical properties of these mine soils.

3. Evaluate biochemical properties of weathered brown sandstone and un-weathered gray sandstone amended with hydroseed. 


\subsection{References}

Burger, JA., D. Mitchem, C.E. Zipper, and R. Williams. 2008. Native hardwood reforestation after five years for phase III bond release. In: Barnhisel RI (ed.), 25th Annual national conference of the American Society of Mining and Reclamation, Lexington, pp. 192-20

Burger, J., D. Graves, P. Angel, V. Davis, and C. Zipper. 2005. The forestry reclamation approach. Office of Surface Mining. Washington, D.C.

Byrd, J.E., R.K. Kolka, R.C. Warner, and J.M. Ringe. 2002. Soil water percolation and erosion on uncompacted surface mine soil in eastern Kentucky. In: R.I. Barnhisel (ed.), Proc. 2002 National Meeting of the American Society of Mining and Reclamation, Lexington, KY, June 9-13, 2002. American Society of Mining and Reclamation (ASMR). Lexington, KY.pp. 1049-1059.

Gorman, J., J. Skousen, J. Sencindiver, and P. Ziemkiewicz. 2001. Forest productivity and minesoil development under a white pine plantation versus natural vegetation after 30 years. p. 103-111. In Proc. of the 18th Annual Meet., Albuquerque, NM. 2-7 June 2001.Am. Soc. for Mining and Reclamation, Lexington, KY

Larkin J.L., D.S. Maehr, J.J. Krupa, J.J. Cox, K. Alexy, D.E. Unger, and C. Barton. 2008. Small mammal response to vegetation and spoil conditions on a reclaimed surface mine in eastern Kentucky. Southeastern Naturalist 7:401-412.

Showalter J., J.A. Burger, C.E. Zipper, J.M. Galbraith, and P. Donovan. 2007. Physical, chemical, and biological mine soil properties influence white oak seedling growth: a proposed mine soil classification model. Southern Journal of Applied Forestry 31:99107.

Simmons J., W. Currie, K.N. Eshleman, K. Kuers, S. Monteleone, T.L. Negley, B. Pohlad, and C. Thomas. 2008. Forest to reclaimed land use change leads to altered ecosystem structure and function. Ecological Applications 18:104-11.

Skousen, J., P. Ziemkiewicz, and C. Venable. 2006. Tree recruitment and growth on 20-yr-old, unreclaimed surface mined lands in West Virginia. International J. Mining, Reclamation and Environment 20(2):142-154.

Torbert, J.L., and J.A. Burger. 2000. Forest land reclamation. p. 371-398. In: Reclamation of Drastically Disturbed Lands. (eds R.I. Barnhisel, R.G. Darmody, and W.L. Daniels). American Society of Agronomy, Madison, WI. 
Townsend P.A., D.P. Helmers, C.C. Kingdon, B.E. McNeil, K.M. de Beurs, and K.N. Eshleman. 2009. Changes in the extent of surface mining and reclamation in the Central Appalachians detected using a1976-2006 Landsat time series. Remote Sensing of Environment 113:62-72.

Wickham, J.D., K.H. Riitters, T.G. Wade, M. Coan, and C. Homer. 2007. The effect of Appalachian mountaintop mining on interior forest. Landscape Ecol, 22:179-187.

Zipper, C., J. Burger, J. Skousen, P. Angel, C. Barton, V. Davis, and J. Franklin. 2011. Restoring forests and associated ecosystem services on Appalachian coal surface mines. Environ. Management 47:751-765. 


\section{Samples Mine}

\subsection{Literature Review and Objectives}

The Appalachian Regional Reforestation Initiative has adopted a forestry reclamation approach (FRA) that includes five factors that contribute to healthy tree growth on reclaimed mine sites (Burger et al., 2005; Zipper et al., 2011). These include (1) substrate selection, (2) substrate placement, (3) tree selection, (4) herbaceous vegetation selection and application rate, and (5) tree planting technique. Mulch application, while not recognized as a step in the FRA, is an important component of revegetation practice to protect soil while vegetation is becoming established, and it is required by regulation. Mulch imparts beneficial characteristics to the soil growth material and can improve tree growth by conserving soil and modifying its properties.

Substrate selection has been shown to be a controlling factor in the success of post-mining land use. Studies by McFee et al. (1981), Torbert et al., (1990) and Casselman (2006) found that substrates derived from shale and siltstone reduced tree growth when compared to growth of trees in substrates derived from sandstone overburden. Two types of sandstone materials are often placed on the surface during reclamation in West Virginia. The differences in these substrates are mainly a result of their respective location in the geologic column. Oxidized sandstone, commonly called brown sandstone, is found closer to the surface and has been subjected to oxidizing conditions that typically produce materials with a $\mathrm{pH}$ ranging from 4.0 to 5.5 (Hearing et al., 2004). Un-oxidized sandstone, commonly referred to as gray sandstone, is generally more abundant and is located lower (below $10 \mathrm{~m}$ ) in the geologic column (Grube et al., 1982). Consequently, these materials remain un-oxidized until moved to the surface. The $\mathrm{pH}$ of soils derived from this type of material is usually within the range of 7.5 to 8.0 (Hearing et al., 
2004). Torbert and Burger (2000) explained that the oxidized brown sandstone located close to the pre-mining surface possesses chemical and physical characteristics that benefit tree growth. In addition to a lower $\mathrm{pH}$, these materials tend to have lower levels of soluble salts and higher percentages of fines $(<2 \mathrm{~mm})$ when compared to their un-oxidized gray sandstone counterparts. Studies by Daniels and Amos (1984), Torbert et al. (1988), Andrews et al. (1998), Rodrigue and Burger (2004), and Emerson et al. (2009) support this idea by citing low electrical conductivity, high percentages of fines and lower $\mathrm{pH}$, amongst other properties, as being correlated to better tree growth.

Researchers conducting studies directly comparing these two types of sandstone-derived mine soils have reported higher growth in trees planted into oxidized types (Angel et al. 2008; Emerson et al., 2009; Showalter et al., 2010). This research has raised concerns about the ability of un-oxidized sandstone-derived mine soils to perform as a topsoil substitute. To make use of the abundance of this material, studies have examined tree growth in soils derived from mixtures (Angel et al., 2008) and mine soils amended with forest topsoil (Showalter et al., 2010). Both have reported growth to remain lower than growth in only oxidized sandstone-derived mine soils.

Compaction of surface materials is a required practice when regrading overburden materials to achieve post-mining land forms and to meet land stability safety regulations. After the final land contours are established and stabilized, operators then replace topsoil materials at suitable depths for the desired post-mining land use. When reclaiming surface mined lands to hay and pasture post-mining land uses, topsoil is replaced to depths of $15-50 \mathrm{~cm}$ depending on the amount salvaged prior to mining. As the last step of the process, bulldozers spread this material 
and "track in" the soil leaving a uniform ground surface for seeding of aggressive forage species (Skousen and Zipper, 2010; Torbert and Burger, 2000). This process for reclaiming surface mined lands to pasture and hay land is well known and practiced, which results in complete coverage of the ground surface with quick establishing and persistent herbaceous species.

In forestry reclamation post-mining land uses, compaction of the ground surface in a similar manner as that done for pasture reclamation has been shown to prohibit good tree growth. Geyer (1972) found that tree growth in Kansas mine spoils was adversely affected by excessive compaction. Spoil banks with little or no grading had a higher survival rate in the first year and mortality in graded spoil banks increased over a 16-year period. Compaction was more closely correlated to survival and growth than substrate type. Heilman (1981) reported that Douglas fir (Pseudotsuga menziesii Mirb.) planted in soils with lower bulk density exhibited deeper and more extensive root systems than those planted on highly compacted soils. The better growth was attributed to the ability for root expansion and exploration for additional water and nutrients. In 1986, Daniels and Amos (1985) found that of 30 mine sites with weathered materials on the surface which had sparse or no vegetation, only one was found to be acidic. The other sites with poor vegetation were not due to other poor chemical properties, but the factor limiting plant growth at the other study sites was soil compaction. Therefore, compaction was the limiting factor for sites with favorable chemical properties where tree growth was shown to be poor. Compacted soils have less pore space with which to hold water and air needed for plant growth. Compacted soils prevent root expansion and water infiltration, both of which limit water availability during droughty conditions. Even small amounts of traffic on the surface increase compaction and lead to conditions that significantly reduce tree growth and survival (Angel et al., 2006). A number of studies with a variety of tree species have found that compaction reduces 
tree survival and growth on disturbed land (Clayton et al., 1987, Lockaby et al., 1984; Torbert et al., 1988; Zeleznik and Skousen, 1996). Compaction was also cited as a hindrance to organic matter and $\mathrm{N}$ accumulation in Appalachian soils resulting in low microbial activity (Stroo and Jencks, 1982). Andrews et al. (1992 and 1998) found that rooting depth was the major limiting factor in tree growth, particularly white pine (Pinus strobus L.) on Virginia and West Virginia mine soils. Compacted layers found beneath the surface prevented root penetration.

To ameliorate the effects of compaction, researchers have found that ripping the surface layers of the site can help to reduce bulk density and increase tree growth. Like Heilman (1981), Philo et al. (1982) found that black walnut (Juglans nigra L.) seeded on ripped spoils established better in the first year and had a higher survival rate in the following year than those seeded on un-ripped spoils with similar characteristics. The effects of ripping have been explored by others (Ashby et al., 1997; Cleveland and Kjelgren, 1994; Skousen et al., 2009) and all have found similar results; tree survival and growth increases as bulk density decreases through ripping, but many have also mentioned that ripping still does not make the soil as good as material that was not originally compacted.

The objective of this study was to evaluate tree growth and survival on compacted and noncompacted weathered brown and unweathered gray sandstone substrates and to monitor potential effects of treatments on soil chemical characteristics.

\subsection{Methods}

\subsubsection{Study Area}


The Samples Mine, located $50 \mathrm{~km}$ southeast of Charleston, is owned by Arch-Magnum and operated by Catenary Coal Company. It spans three West Virginia Counties: Kanawha, Raleigh, and Boone. The mining process consisted of a truck/shovel operation and a dragline to excavate overburden from three Kittanning coal seams (7 Block, 6 Block, and 5 Block), and the Stockton, Coalburg, and Winifrede seams. The overburden includes sandstone with thin intermittent layers of shale. The pre-mining soils consisted mainly of a Clymer-Dekalb series (Typic Hapludults Typic Dystrudepts) on moderate to severely steep slopes (Wolf, 1994).

In January 2005, three 2.8-hectare demonstration plots were constructed. Two were composed of $90 \%$ weathered brown sandstone and $10 \%$ pre-mining topsoil. One of these brown sandstone plots had material dumped to a depth of $1.5 \mathrm{~m}$, while the other brown sandstone plot had material dumped at $1.2 \mathrm{~m}$ in depth. A third plot comprised of entirely gray unweathered sandstone was placed on the surface to a depth of $1.5 \mathrm{~m}$. The plots were constructed by enddumping material in adjacent conjoining piles. One half of each plot was graded with one or two passes of a dozer to avoid compaction, which produced a roughly graded surface. The other half of each plot was "tracked in" several times, as is usually done in reclamation to pasture land, producing a highly compacted surface. Six treatments were produced (Table 2-1). The layout of the study area can be seen in Figure 2-1.

Table 2-1. Soil treatment combinations at Catenary Coal's Samples mine operation in Kanawha County, West Virginia.

\begin{tabular}{ll}
\hline Treatment & Abbreviation \\
\hline $1.2-\mathrm{m}$ weathered brown sandstone compacted & $4 \mathrm{BC}$ \\
$1.2-\mathrm{m}$ weathered brown sandstone noncompacted & $4 \mathrm{BNC}$ \\
$1.5-\mathrm{m}$ weathered brown sandstone compacted & $5 \mathrm{BC}$ \\
$1.5-\mathrm{m}$ weathered brown sandstone noncompacted & $5 \mathrm{BNC}$ \\
$1.5-\mathrm{m}$ unweathered gray sandstone compacted & $5 \mathrm{GC}$ \\
$1.5-\mathrm{m}$ unweathered gray sandstone noncompacted & $5 \mathrm{GNC}$ \\
\hline
\end{tabular}



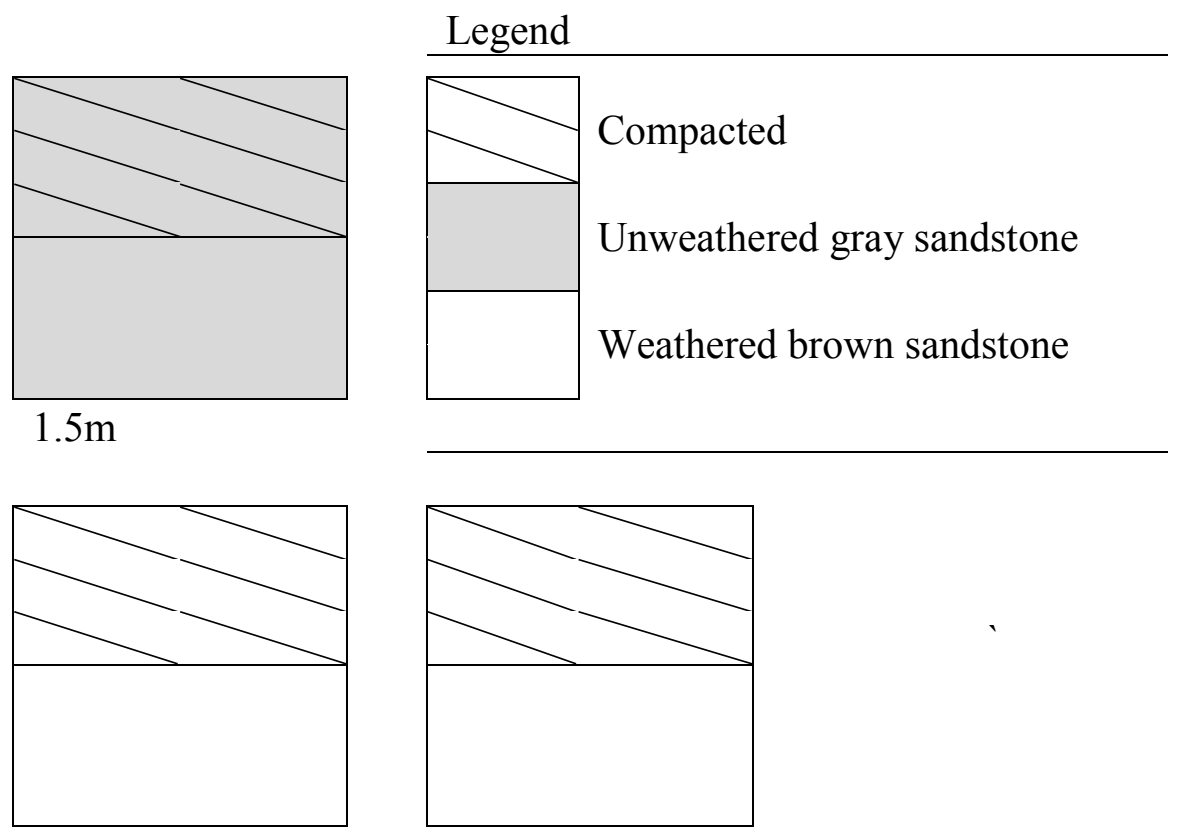

$1.2 \mathrm{~m}$

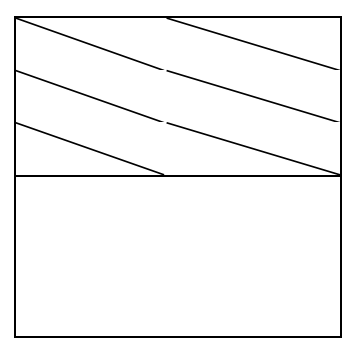

$1.5 \mathrm{~m}$

Figure 2-1. Treatment layout at Catenary Coal's Samples mine operation in Kanawha County, West Virginia. Not to scale.

In March 2005, the demonstration plots were planted with 15,510 trees on 1.8 -m centers resulting in a planting density of 1,846 stems per ha. Eleven species of trees were planted (Table 2-2). However, some species where planted in greater numbers and due to planting strategy, species were not evenly distributed across the sites. In fall 2007, the plots were hydroseeded with a tree compatible ground cover at a seeding rate of $15.4 \mathrm{~kg} / \mathrm{ha}$ (Table $2-3)$. 
Table 2-2. Species and number of trees planted at Catenary Coal's Samples mine operation in Kanawha County, West Virginia.

\begin{tabular}{lcc}
\hline Species & $\begin{array}{c}\text { Number } \\
\text { Planted }\end{array}$ & $\begin{array}{c}\text { \% of Total } \\
\text { Planted }\end{array}$ \\
\hline Black cherry (Prunus serotina Ehrh.) & 465 & 3 \\
Black locust (Robinia pseudoacacia L.) & 465 & 3 \\
Chestnut oak (Quercus prinus L.) & 1,250 & 8 \\
Eastern redbud (Cercis canadensis L.) & 465 & 3 \\
Gray dogwood (Cornus racemosa Lam.) & 465 & 3 \\
Northern red oak (Quercus rubra L.) & 3,400 & 22 \\
Sugar maple (Acer saccharum Marsh.) & 1,500 & 10 \\
Tulip poplar (Liriodendron tulipifera L.) & 1,250 & 8 \\
White ash (Fraxinus americana L.) & 2,500 & 16 \\
White oak (Quercus alba L.) & 2,500 & 16 \\
White pine (Pinus strobus L.) & 1,250 & 8 \\
\hline Total & 15,510 & 100 \\
\hline
\end{tabular}

\begin{tabular}{lc}
$\begin{array}{l}\text { Table 2-3. Species and rate of } \\
\text { hydroseeded at Catenary Coal's } \begin{array}{c}\text { Samples } \\
\text { cover } \\
\text { mine }\end{array} \\
\text { operation in Kanawha County, West Virginia. }\end{array}$ \\
\hline Species & Rate \\
\hline & $\mathrm{kg} \mathrm{ha}^{-1}$ \\
Birdsfoot trefoil (Lotus corniculatus L.) & 11.0 \\
Perennial ryegrass (Lolium perenne L.) & 2.2 \\
Redtop (Agrostis gigantea L.) & 2.2 \\
\hline Total & 15.4 \\
\hline
\end{tabular}

\subsubsection{Trees}

On demonstration plots, transects for monitoring tree survival and growth were arranged in an X pattern. Each transect began at the corner of a demonstration plot and extended $195 \mathrm{~m}$ toward the adjacent corner forming an $\mathrm{X}$ across the plot. Each transect was $2.7 \mathrm{~m}$ wide. The sampling technique for trees utilized two transects in each treatment combination and a total of four transects on each 2.8-ha demonstration plot. Height to highest live growth and stem 
diameter $2.5 \mathrm{~cm}$ above the soil surface were recorded for every tree within all transects. Data collections occurred during the first weeks of August, every year from 2005 to 2011. Volume index was used as a proxy for tree growth. Volume index of tree biomass was calculated with the following equation (Angel et al, 2008; Emerson et al., 2009; Tschaplinski et al., 1998):

$$
\text { Tree volume index }\left(\mathrm{cm}^{3}\right)=\text { Height }(\mathrm{cm}) \times \operatorname{Diameter}^{2}\left(\mathrm{~cm}^{2}\right)
$$

Tree survival was calculated by the difference between the number of trees sampled the first year, 2005 (by Emerson et al., 2009), and the last year, 2011.

\subsubsection{Soil}

In mid-summer from 2005 to 2011 , soil samples from the top $15 \mathrm{~cm}$ were collected at five random locations within the two transects for every treatment combination. Samples were air dried, weighed and passed through a No. 10 sieve. All material less than $2 \mathrm{~mm}$ was weighed and recorded as the fine fraction. The fine fraction was used for chemical analysis (2005 data from Emerson et al., 2009).

Extractable elements were determined using a Mehlich 1 extraction solution. Five grams from the fine fraction of each sample were placed in $45-\mathrm{mL}$ polypropylene centrifuge tubes with $25 \mathrm{~mL}$ of Mehlich 1 extracting solution $\left(0.05 \mathrm{M} \mathrm{HCl}\right.$ and $\left.0.025 \mathrm{M} \mathrm{H}_{2} \mathrm{SO}_{4}\right)$. Supernatant was analyzed for phosphorus, potassium, calcium, magnesium, aluminum, iron, manganese, and zinc using a Perkin Elmer Plasma 400 emission spectrometer.

Soil $\mathrm{pH}$ was measured in a 1:2 mixture of 5 grams of soil and $10 \mathrm{~mL}$ of deionized water. Soluble salts, as determined by electrical conductivity, were measured on a 1:1 mixture consisting of 5 grams soil and $5 \mathrm{~mL}$ deionized water. 


\subsubsection{Ground Cover}

Vegetation cover on demonstration plots was measured using $1-\mathrm{m}^{2}$ quadrats in twenty random locations within the two 2.7-m-wide transect boundaries for each treatment combination. Herbaceous cover, tree cover, standing water, and bare soil/rock were estimated and recorded as a percentage.

\subsubsection{Data Analysis}

Tree growth data were analyzed by one-way ANOVA by substrate, compaction, depth (for brown sandstone plots only), treatment combinations, and species. Tukey's multiple comparison test was used to determine significant differences between group means at $\mathrm{P}<0.05$. Growth of species with three or more individuals in each treatment combination was analyzed by one-way ANOVA by treatment combinations for 2011 data. Tukey's multiple comparison test was used to determine significant differences between group means at $\mathrm{P}<0.05$.

Soil data were analyzed by one-way ANOVA by treatment combinations within year for $\mathrm{pH}$, percent fines, percent fines, EC, and extractable elements. Tukey's multiple comparison test was used to determine significant differences at $\mathrm{P}<0.05$. Soil data were also analyzed by t-test among years within treatment combinations.

Ground cover data were analyzed by one-way ANOVA to compare cover types (herbaceous,

tree, bare soil or rock, water, and total cover) by soil treatment combinations for 2011. Tukey's multiple comparison test was used to determine significant differences at $\mathrm{P}<0.05$. We used the $\mathrm{R}$ language and Environment for Statistical Computing for all the above analyses ( $\mathrm{R}$ Development Core Team, 2011). 


\subsection{Results}

\subsubsection{Trees}

The effect of substrate type on tree growth was found to be significant at $\mathrm{P}<0.5$ (Table 2-4). Weathered brown sandstone showed significantly higher tree growth than unweathered gray sandstone with volume indices of $3504 \mathrm{~cm}^{3}$ versus $266 \mathrm{~cm}^{3}$, respectively. Trees grown in weathered brown sandstone not only had a higher mean, they exhibited a wider range of values than trees grown in unweathered gray sandstone (Figure 2-2). Compaction treatment was not a significant factor in tree survival and volume growth index. Therefore, significant differences in treatment combination were only related to substrate type. Depth treatment in brown sandstone plots were significant at a $\mathrm{P}<0.1$. Tree volume index was greater in the $1.5-\mathrm{m}$ deep plot with a mean index of $4273 \mathrm{~cm}^{3}$. Mean volume index on the 1.2-m deep plot was nearly half (Table 2-4). Species was a significant factor at $\mathrm{P}<0.1$. 
Table 2-4. Main treatment effects for volume index and survival after seven growing seasons in four soil treatments at Catenary Coal's Samples mine in Kanawha County, WV.

\begin{tabular}{|c|c|c|c|}
\hline & & $\begin{array}{l}\text { Volume } \\
\text { Index }\end{array}$ & Survival \\
\hline & & $\mathrm{cm} 3$ & $\%$ \\
\hline \multicolumn{4}{|l|}{ Topsoil } \\
\hline & Brown Sandstone & $3504^{a}+$ & 88 \\
\hline & Gray Sandstone & $266^{\mathrm{b}}$ & 69 \\
\hline & Compacted & 1427 & 81 \\
\hline & Non-compacted & 1439 & 81 \\
\hline & $1.2 \mathrm{~m}$ depth & $2735^{b}$ & 87 \\
\hline & $1.5 \mathrm{~m}$ depth & $4273^{\mathrm{a}}$ & 88 \\
\hline \multicolumn{4}{|l|}{$\begin{array}{l}\text { Treatment } \\
\text { Combinations }\end{array}$} \\
\hline & $4 \mathrm{BC} \dagger$ & $1632^{\mathrm{a}}$ & 87 \\
\hline & 4BNC & $3685^{\mathrm{a}}$ & 87 \\
\hline & $5 \mathrm{BC}$ & $6689^{\mathrm{a}}$ & 83 \\
\hline & $5 \mathrm{BNC}$ & $2279^{\mathrm{a}}$ & 93 \\
\hline & $5 \mathrm{GC}$ & $271^{\mathrm{b}}$ & 71 \\
\hline & $5 \mathrm{GNC}$ & $262^{b}$ & 67 \\
\hline \multicolumn{4}{|l|}{ Species } \\
\hline & Black Cherry & $1004^{\mathrm{bc}}$ & 33 \\
\hline & Black Locust & $7924^{\mathrm{a}}$ & 100 \\
\hline & Dogwood & $1832^{b}$ & 63 \\
\hline & Redbud & $812^{\mathrm{bc}}$ & 50 \\
\hline & Red Oak & $1434^{b}$ & 73 \\
\hline & Sugar Maple & $156^{\mathrm{c}}$ & 40 \\
\hline & Tulip Poplar & $893^{b c}$ & 63 \\
\hline & White Ash & $731^{\mathrm{bc}}$ & 83 \\
\hline & White Oak & $1554^{\mathrm{b}}$ & 82 \\
\hline & White Pine & $650^{\mathrm{bc}}$ & 77 \\
\hline
\end{tabular}

$\uparrow$ See Table 2-1 for treatment descriptions.

tmeans for each treatment within column group with the same letter are not significantly different at $\mathrm{P}<0.05$. 


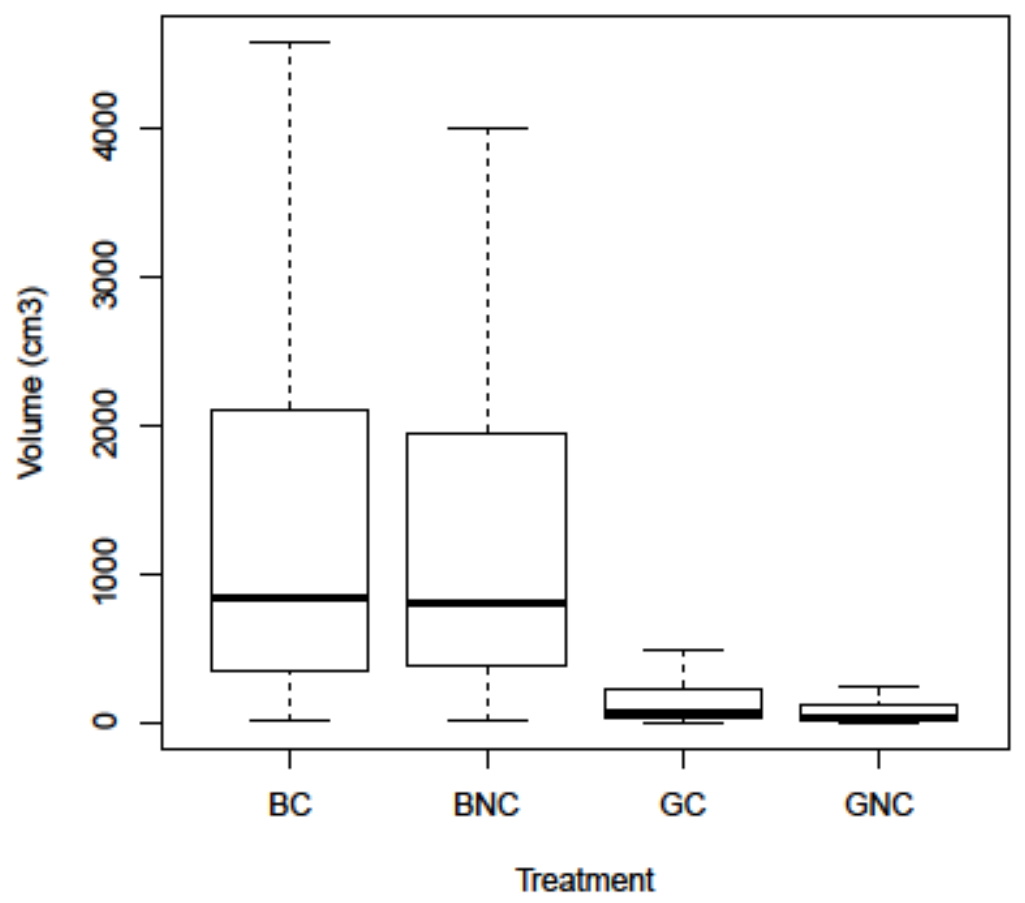

Figure 2-2. Boxplot of tree volume index of all tree species for four soil treatments at Catenary Coal's Samples mine in Kanawha County, WV.

Black locust had the highest average volume index across all plots at a mean index of 7924 $\mathrm{cm}^{3}$, which result is commonly found on reclaimed areas. It is the first to colonize reclaimed sites and if planted it grows rapidly and expands where space is available. Black locust is a legume and fixes nitrogen thereby allowing it to proliferate on infertile mine soils. Dogwood had the next highest mean volume index of all species in the study with a mean volume index of $1833 \mathrm{~cm}^{3}$. However there were no individuals of this species found in the GNC treatment combination (Table 2-5), which if there were would have undoubtedly reduced the mean growth index. Sugar maple had the lowest mean volume $\left(156 \mathrm{~cm}^{3}\right)$ among species. There were no significant differences for mean sugar maple volume index among treatment combinations (Table 2-6). However, Figure 2-3 illustrates the range of values for sugar maple volume index 
and suggests that this species is capable of achieving high levels of growth in weathered brown sandstone compared to the limited range of volume index of trees grown in gray sandstone.

Table 2-5. Distribution of tree species in 2011 after seven growing seasons in four soil treatments at Catenary Coal's Samples mine in Kanawha County, WV.

\begin{tabular}{lccccccc}
\hline & \multicolumn{7}{c}{ Treatment $\dagger$} \\
\cline { 2 - 8 } Species & 4BC & 4BNC & 5BC & 5BNC & 5GC & 5GNC & Total \\
\hline Black cherry & 1 & - & 2 & 1 & - & 2 & 6 \\
Black locust & 27 & 36 & 11 & 36 & 1 & 5 & 116 \\
Dogwood & 1 & 4 & 1 & 4 & 7 & - & 17 \\
Redbud & 1 & 6 & 3 & 2 & - & 3 & 15 \\
Red oak & 12 & 16 & 14 & 14 & 14 & 20 & 90 \\
Sugar maple & 3 & - & 8 & 6 & 5 & 3 & 25 \\
Tulip popular & 5 & 1 & 7 & 8 & 6 & 7 & 34 \\
White oak & 16 & 25 & 14 & 17 & 4 & 11 & 87 \\
White ash & 18 & 9 & 19 & 8 & 14 & 11 & 79 \\
White pine & 3 & 4 & 6 & 4 & 6 & 4 & 27 \\
Total & 87 & 101 & 85 & 100 & 57 & 66 & 496 \\
\hline
\end{tabular}

$\dagger$ see Table 2-1 for treatment descriptions

Only four of the species did not have three or more individuals in each treatment combination: Black cherry, Black locust, Dogwood, and Redbud (Table 2-5). Of the species represented by three or more individuals in each treatment, four showed significant differences with respect to mean volume index among treatment combinations: red oak, white ash, white oak, white pine (Table 2-6). All four showed a similar trend described earlier for sugar maple with respect to substrate type and value range (Figures 2-4, 2-5, 2-6, and 2-7). Tulip poplar exhibited a variable range across treatment combinations, with lower (but not significant) means for treatment combinations with gray sandstone (Figure 2-8).

Due to the relatively even distribution of red oak individuals (Table 2-5), we were able to evaluate red oak survival and volume index alone in a similar manner as for all tree species grouped together. Red oak behaved in a similar manner with brown plots having significantly 
greater volume index, but with the exception that depth treatment in brown plots was not significantly different (Table 2-7).

Table 2-6. Mean tree volume index of tree species in 2011 after seven growing seasons in four soil treatments at Catenary Coal's Samples mine in Kanawha County, WV.

\begin{tabular}{lccccccc}
\hline & \multicolumn{7}{c}{ Treatment ${ }^{\dagger}$} \\
\cline { 2 - 7 } Species & 4BC & 4BNC & 5BC & 5BNC & 5GC & 5GNC & Ave \\
\hline Black cherry & 869 & - & 2158 & 523 & - & 161 & $1004^{\mathrm{bc}}$ \\
Black locust & 2437 & 6787 & 41184 & 4070 & 47 & 1901 & $7924^{\mathrm{a}}$ \\
Dogwood & 812 & 1537 & 793 & 4683 & 668 & - & $1832^{\mathrm{b}}$ \\
Redbud & 1040 & 1276 & 1025 & 178 & - & 22 & $812^{\mathrm{bc}}$ \\
Red oak & $1174^{\mathrm{b}}+$ & $2962^{\mathrm{a}}$ & $3061^{\mathrm{a}}$ & $798^{\mathrm{b}}$ & $262^{\mathrm{b}}$ & $76^{\mathrm{b}}$ & $1434^{\mathrm{b}}$ \\
Sugar maple & 113 & - & 217 & 228 & 80 & 20 & $156^{\mathrm{c}}$ \\
Tulip popular & 646 & 527 & 1429 & 1445 & 351 & 423 & $893^{\mathrm{bc}}$ \\
White oak & $1453^{\mathrm{ab}}$ & $1507^{\mathrm{ab}}$ & $2104^{\mathrm{a}}$ & $1072^{\mathrm{ab}}$ & $5^{\mathrm{b}}$ & $140^{\mathrm{b}}$ & $731^{\mathrm{bc}}$ \\
White ash & $970^{\mathrm{a}}$ & $993^{\mathrm{a}}$ & $992^{\mathrm{a}}$ & $929^{\mathrm{ab}}$ & $296^{\mathrm{ab}}$ & $90^{\mathrm{b}}$ & $1554^{\mathrm{b}}$ \\
White pine & $2004^{\mathrm{a}}$ & $914^{\mathrm{b}}$ & $743^{\mathrm{b}}$ & $662^{\mathrm{b}}$ & $72^{\mathrm{b}}$ & $87^{\mathrm{b}}$ & $650^{\mathrm{bc}}$ \\
Ave & $1632^{\mathrm{a}}$ & $3685^{\mathrm{a}}$ & $6689^{\mathrm{a}}$ & $2279^{\mathrm{a}}$ & $271^{\mathrm{b}}$ & $262^{\mathrm{b}}$ & \\
\hline
\end{tabular}

$\dagger$ see Table 2-1 for treatment descriptions

$\$$ means for each treatment combination within rows with the same letter are not significantly different at $\mathrm{P}<0.05$. Significant differences were found only for species with 3 or more trees in every treatment combination. 
Table 2-7. Main treatment effects for volume index and survival of Red oak after seven growing seasons in four soil treatments at Catenary Coal's Samples mine in Kanawha County, WV.

\begin{tabular}{ccc}
\hline & Volume & Survival \\
\hline $\mathrm{cm}^{3}$ & $\%$
\end{tabular}

Topsoil

\begin{tabular}{lcc} 
Brown & & \\
Sandstone & $2232^{\mathrm{a} \ddagger}$ & 72 \\
Gray Sandstone & $161^{\mathrm{b}}$ & 73 \\
& & \\
Compacted & 1427 & 64 \\
Non-compacted & 1439 & 82 \\
& & \\
1.2 m depth & 2195 & 82 \\
1.5 m depth & 2266 & 65 \\
& & \\
& & \\
4BC $\dagger$ & $1174^{\mathrm{a}}$ & 85 \\
4BNC & $2961^{\mathrm{a}}$ & 80 \\
5BC & $3061^{\mathrm{a}}$ & 56 \\
5BNC & $1611^{\mathrm{a}}$ & 77 \\
5GC & $261^{\mathrm{b}}$ & 60 \\
5GNC & $76^{\mathrm{c}}$ & 86 \\
\hline
\end{tabular}

$\uparrow$ See Table 2-1 for treatment descriptions.

tmeans for each treatment within column group with the same letter are not significantly different at $\mathrm{P}<0.05$. 


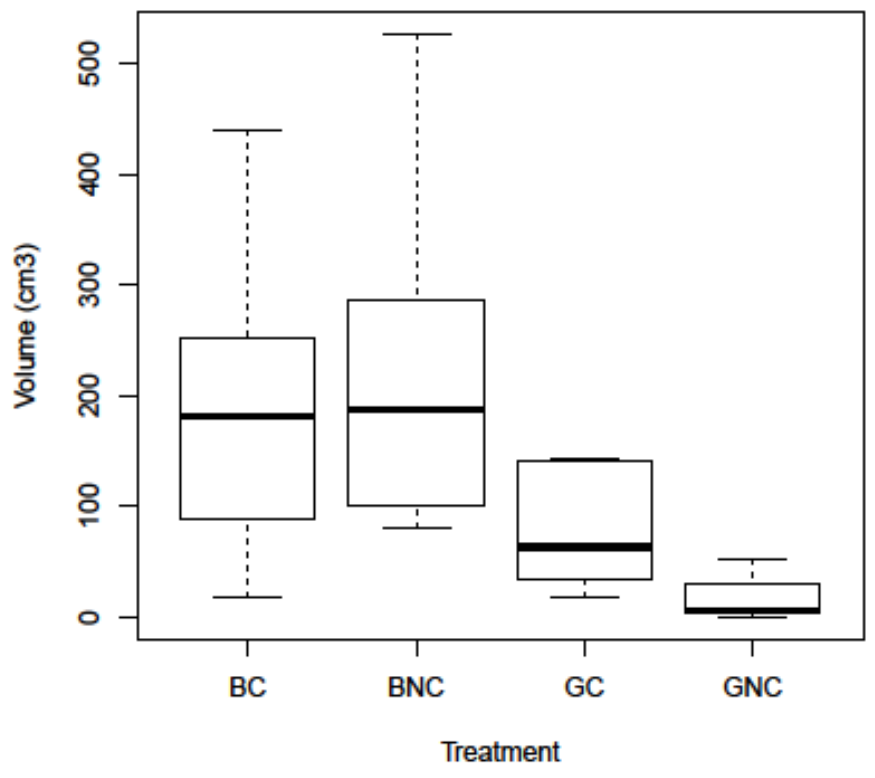

Figure 2-3. Boxplot of Sugar maple volume index for four soil treatments at Catenary Coal's Samples mine in Kanawha County, WV.

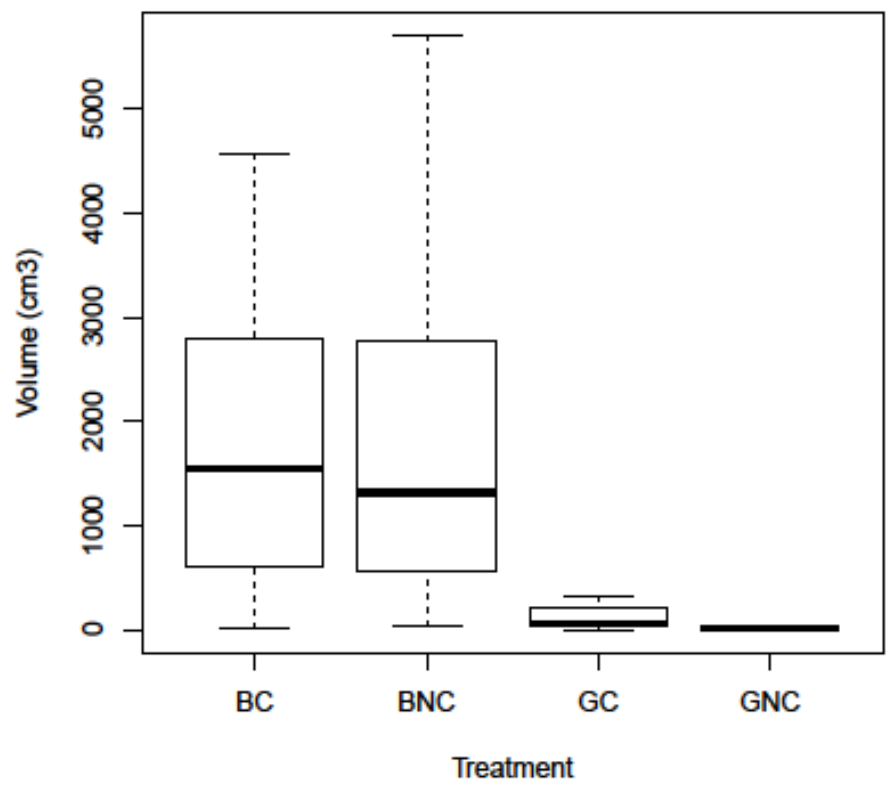

Figure 2-4. Boxplot of Red oak volume index for four soil treatments at Catenary Coal's Samples mine in Kanawha County, WV. 


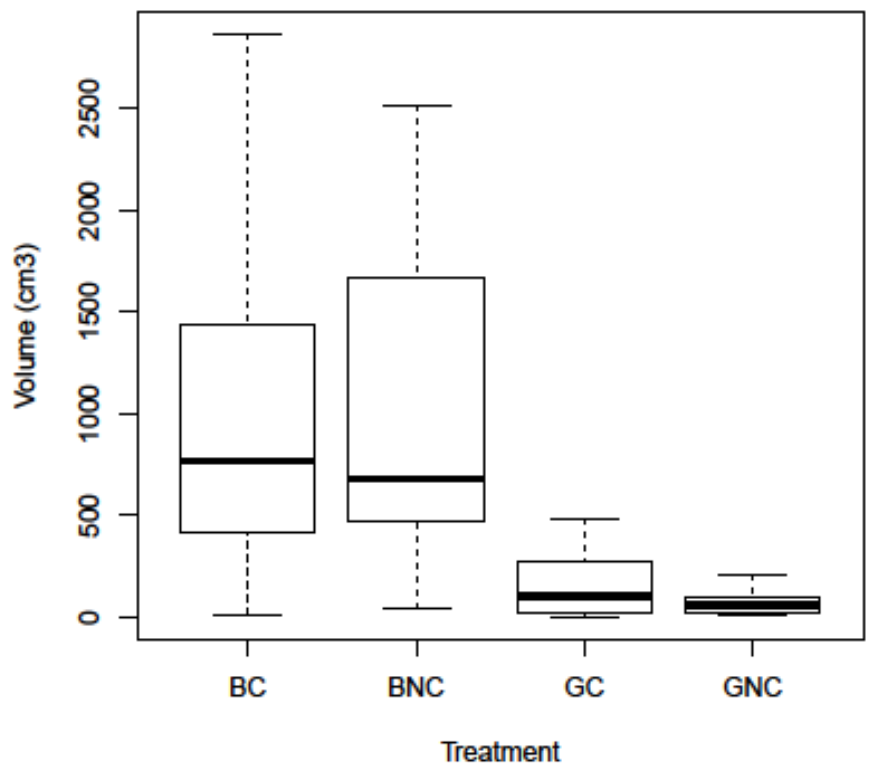

Figure 2-5. Boxplot of White ash volume index for four soil treatments at Catenary Coal's Samples mine in Kanawha County, WV.

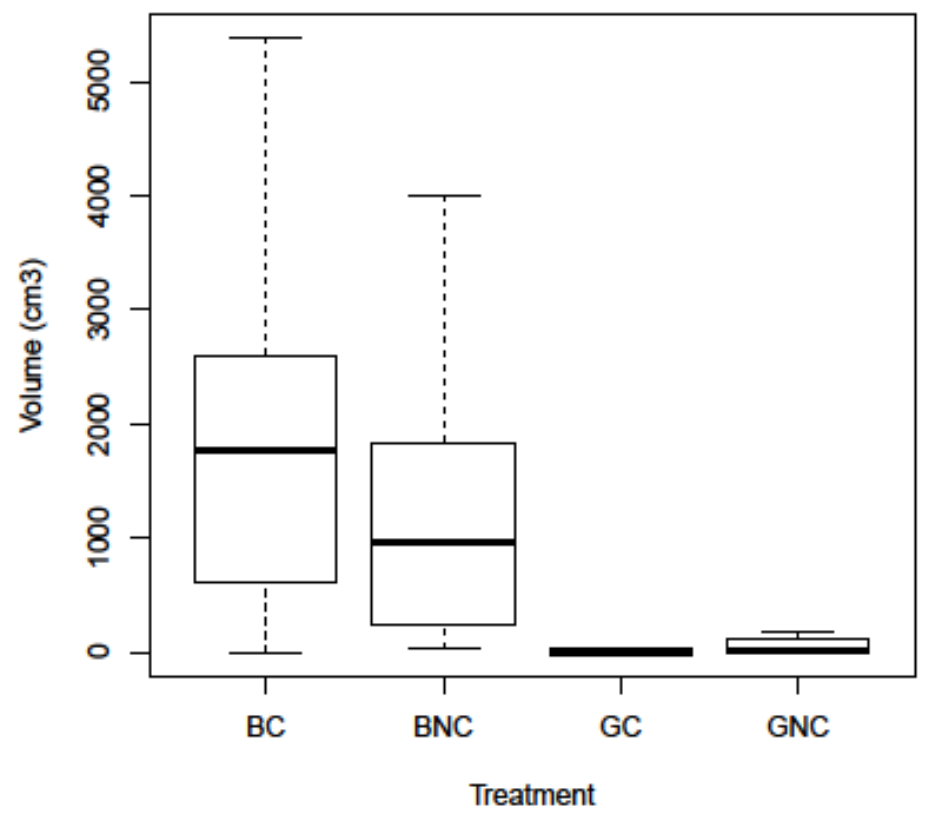

Figure 2-6. Boxplot of White oak volume index in for four soil treatments at Catenary Coal's Samples mine in Kanawha County, WV. 


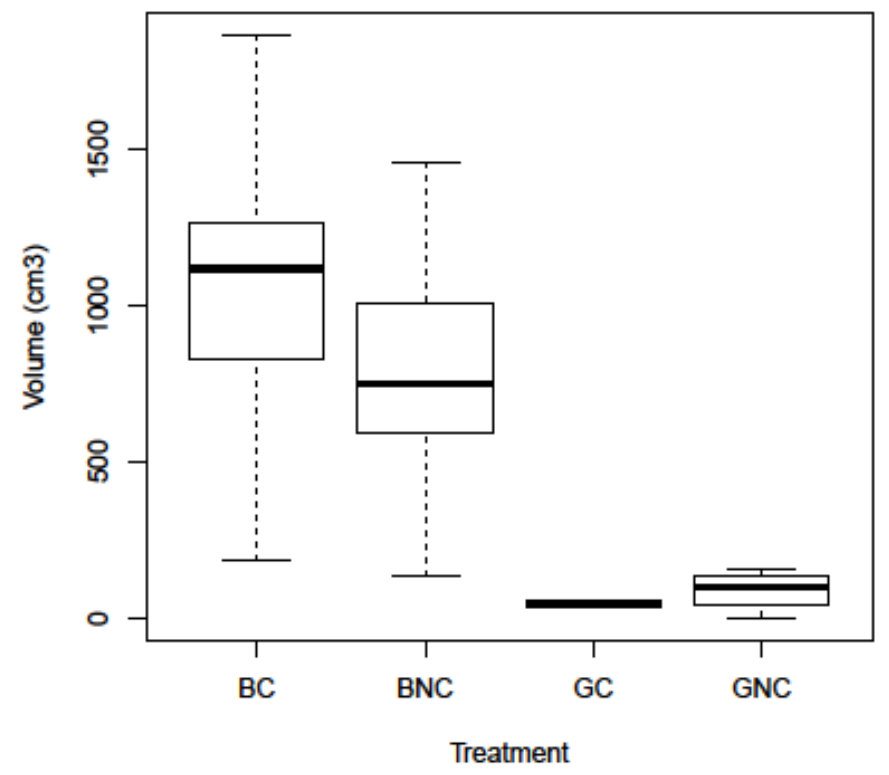

Figure 2-7. Boxplot of White pine volume index in four soil treatments at Catenary Coal's Samples mine in Kanawha County, WV.

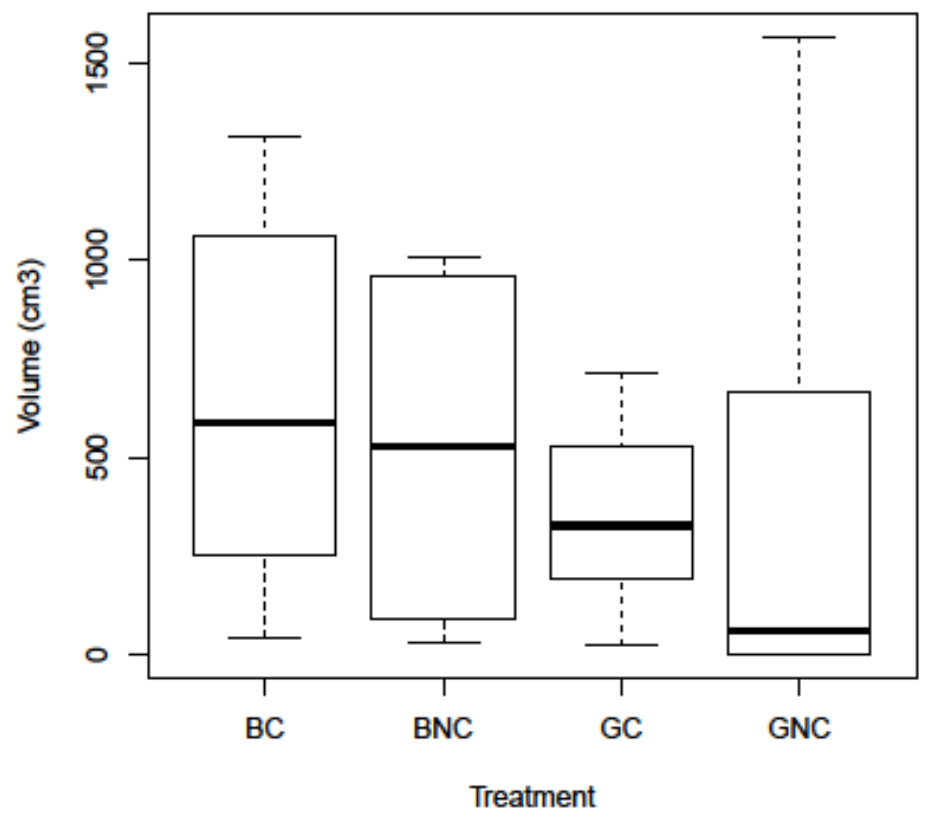

Figure 2-8. Boxplot of Tulip poplar volume index for four soil treatments at Catenary Coal's Samples mine in Kanawha County, WV. 


\subsubsection{Soil}

It was found that depth treatment had no impact on soil properties. Therefore for ease of interpretation and discussion, $1.2 \mathrm{-m}$ and $1.5 \mathrm{-m}$ brown sandstone plots were combined and treated as one treatment. Therefore treatment combinations will be those found in Table 2-8.

Table 2-8. Soil treatment combinations at Catenary Coal's
Samples mine operation in Kanawha County,

There were significant differences between 2005 and 2011 for pH, EC, and Fines (Table 29). Soil $\mathrm{pH}$ was significantly different among soil treatments with brown sandstone plots having a pH from 5 to 6 , and gray sandstone plots being between 7 and 8 . No changes were seen in soil pH within soil treatments between 2005 and 2011. Electrical conductivity of gray sandstone treatments decreased significantly from 2005 to 2011. Fines were significantly lower in gray compared to brown sandstone plots in 2005, and that finding was continued through 2011. All elements showed a significant change between 2005 and 2011 for most soil treatments.

Overall, $\mathrm{pH}$, Fines, $\mathrm{Al}, \mathrm{Fe}, \mathrm{P}$, and $\mathrm{Zn}$ were significantly different between soil types (Tables 2-9 and 2-10). No soil chemical properties were significantly affected by compaction treatment. Not all treatments were significantly different for $\mathrm{pH}, \mathrm{EC}$, and fines between 2005 and 2011. Treatment combination $\mathrm{BC}$ was significantly different between years with regard to $\mathrm{pH}$ 
(although the change was not large). Electrical conductivity of gray sandstone treatments decreased significantly from 2005 to 2011 due to leaching of salts from particle surfaces. All

elements showed a significant change between 2005 and 2011 for most treatment combinations.

Table 2-9. Soil properties of samples from four soil treatments at Catenary Coal's Samples mine in Kanawha County, WV.**

\begin{tabular}{|c|c|c|c|c|}
\hline \multirow[b]{2}{*}{ Properties } & \multicolumn{4}{|c|}{ Treatments $\dagger$} \\
\hline & BC & BNC & GC & GNC \\
\hline $\mathrm{pH}$ & ---- & 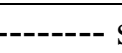 & ----------. & ---- \\
\hline 2005 & $* 4.9^{\mathrm{b}} t$ & $5.3^{\mathrm{b}}$ & $7.4^{\mathrm{a}}$ & $8.2^{\mathrm{a}}$ \\
\hline 2011 & $5.7^{\mathrm{b}}$ & $5.5^{\mathrm{b}}$ & $7.9^{\mathrm{a}}$ & $7.9^{\mathrm{a}}$ \\
\hline Electrical conductivity & ---- & dS & $n^{-1}-\cdots$ & --- \\
\hline 2005 & $0.55^{\mathrm{a}}$ & $0.38^{\mathrm{ab}}$ & ${ }^{*} 0.17^{\mathrm{ab}}$ & ${ }^{*} 0.22^{\mathrm{b}}$ \\
\hline 2011 & 0.51 & 0.42 & 0.40 & 0.40 \\
\hline Fines & -- & ----- & ------- & --- \\
\hline 2005 & $53^{\mathrm{a}}$ & $50^{\mathrm{a}}$ & $40^{\mathrm{b}}$ & $38^{\mathrm{b}}$ \\
\hline 2011 & $50^{\mathrm{a}}$ & $53^{\mathrm{a}}$ & $38^{\mathrm{b}}$ & $36^{\mathrm{b}}$ \\
\hline
\end{tabular}

$\dagger$ see Table 2-8 for treatment descriptions.

$\$$ means for each treatment combination within rows with the same letter are not significantly different at $\mathrm{P}<0.05$.

*denotes significantly different with that property between 2005 and 2011

**2005 soil data from Emerson et al. (2009). 
Table 2-10. Soil properties of samples from four soil treatments at Catenary Coal's Samples mine in Kanawha County, WV.**

\begin{tabular}{|c|c|c|c|c|}
\hline \multirow[b]{2}{*}{ Elements } & \multicolumn{4}{|c|}{ Treatments $\dagger$} \\
\hline & BC & BNC & GC & GNC \\
\hline & \multicolumn{4}{|c|}{ - - } \\
\hline \multicolumn{5}{|c|}{ 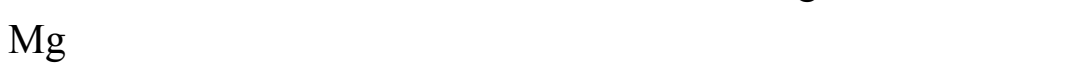 } \\
\hline 2005 & *9.9 & *7.2 & ${ }^{*} 7.8$ & *7.6 \\
\hline 2011 & 4.7 & 3.9 & 6.0 & 5.1 \\
\hline \multicolumn{5}{|l|}{$\mathrm{K}$} \\
\hline 2005 & ${ }^{*} 0.92$ & ${ }^{*} 0.92$ & ${ }^{*} 0.87$ & ${ }^{*} 0.83$ \\
\hline 2011 & $0.42^{\mathrm{a}}$ & $0.35^{\mathrm{ab}}$ & $0.26^{\mathrm{b}}$ & $0.25^{\mathrm{b}}$ \\
\hline \multicolumn{5}{|l|}{$\mathrm{Ca}$} \\
\hline 2005 & 13 & ${ }^{*} 10$ & ${ }^{*} 16$ & *14 \\
\hline 2011 & 13 & 4.5 & 8.0 & 9.5 \\
\hline $\mathrm{Al}$ & \multicolumn{4}{|c|}{--------- $\mathrm{mg} \mathrm{kg}^{-1}$---------- } \\
\hline 2005 & ${ }^{*} 580^{\mathrm{ab}}$ & ${ }^{*} 610^{\mathrm{a}}$ & ${ }^{*} 302^{\mathrm{ab}}$ & ${ }^{*} 202^{\mathrm{b}}$ \\
\hline 2011 & $315^{\mathrm{ab}}$ & $370^{\mathrm{a}}$ & $116^{\mathrm{bc}}$ & $104^{\mathrm{c}}$ \\
\hline \multicolumn{5}{|l|}{$\mathrm{Fe}$} \\
\hline 2005 & *375 & *615 & 617 & *1054 \\
\hline 2011 & $160^{\mathrm{b}}$ & $160^{\mathrm{b}}$ & $330^{\mathrm{a}}$ & $330^{\mathrm{a}}$ \\
\hline \multicolumn{5}{|l|}{$\mathrm{Mn}$} \\
\hline 2005 & $* 495^{\mathrm{a}}$ & ${ }^{*} 383^{\mathrm{ab}}$ & $257^{\mathrm{ab}}$ & ${ }^{*} 115^{\mathrm{b}}$ \\
\hline 2011 & 163 & 140 & 174 & 191 \\
\hline \multicolumn{5}{|l|}{$\mathrm{P}$} \\
\hline 2005 & ${ }^{*} 720$ & *720 & *677 & *645 \\
\hline 2011 & $60^{\mathrm{b}}$ & $60^{\mathrm{b}}$ & $190^{\mathrm{a}}$ & $184^{\mathrm{a}}$ \\
\hline \multicolumn{5}{|l|}{$\mathrm{Zn}$} \\
\hline 2005 & ${ }^{*} 13^{\mathrm{b}}$ & ${ }^{*} 15^{\mathrm{ab}}$ & ${ }^{*} 22^{\mathrm{ab}}$ & $28^{\mathrm{a}}$ \\
\hline 2011 & $9^{b}$ & $6^{\mathrm{b}}$ & $15^{\mathrm{a}}$ & $17^{\mathrm{a}}$ \\
\hline
\end{tabular}

$\dagger$ See table 2-8 for treatment descriptions.

tmeans for each treatment combination within rows with the same letter are not significantly different at $\mathrm{P}<0.05$.

*denotes significantly different within that element between 2005 and 2011.

**2005 soil data from Emerson et al. (2009). 
Aluminum concentrations were significantly higher in weathered brown sandstone treatments (Table 2-10). Concentrations of $\mathrm{Fe}, \mathrm{P}$, and $\mathrm{Zn}$ were all significantly higher in gray sandstone treatments. Both $\mathrm{pH}$ and $\mathrm{Al}$ concentrations in gray showed a small range of values compared to brown sandstone treatment combinations. All extractable nutrients and Al concentrations were significantly lower in 2011.

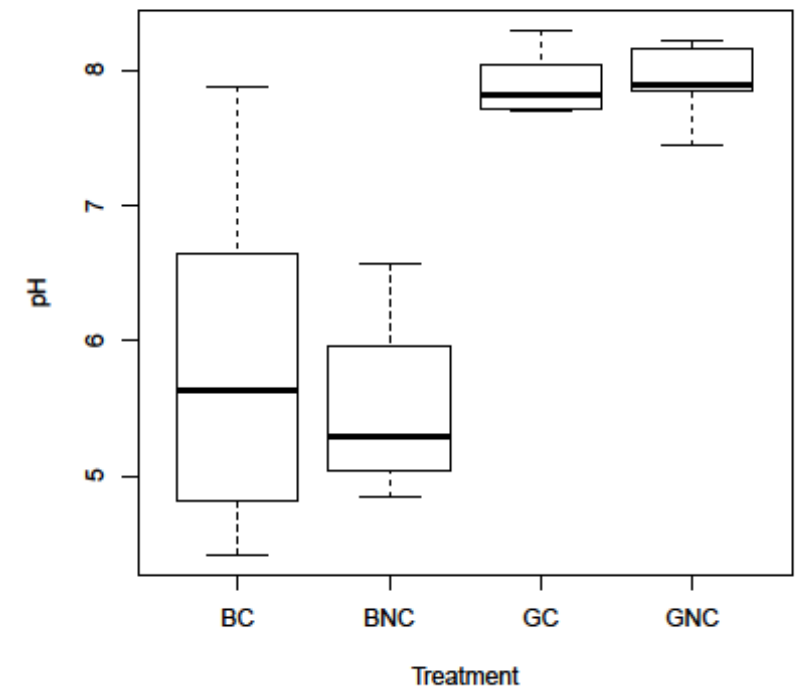

Figure 2-9. Boxplot of soil pH in soil samples of four soil treatments at Catenary Coal's Samples mine in Kanawha County, WV. 


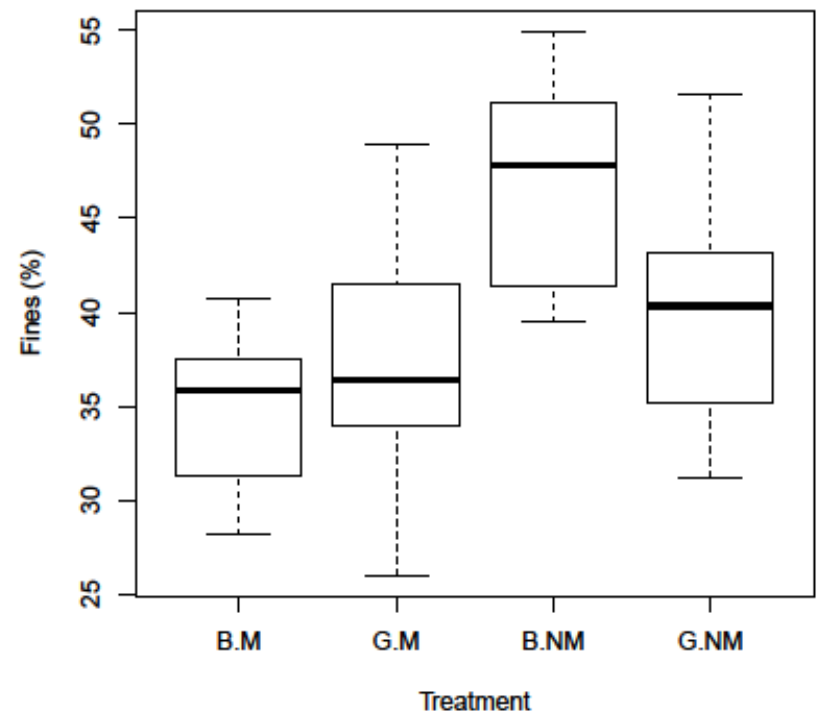

Figure 2-10. Boxplot of \% fines in soil samples of four soil treatments at Catenary Coal's Samples mine in Kanawha County, WV.

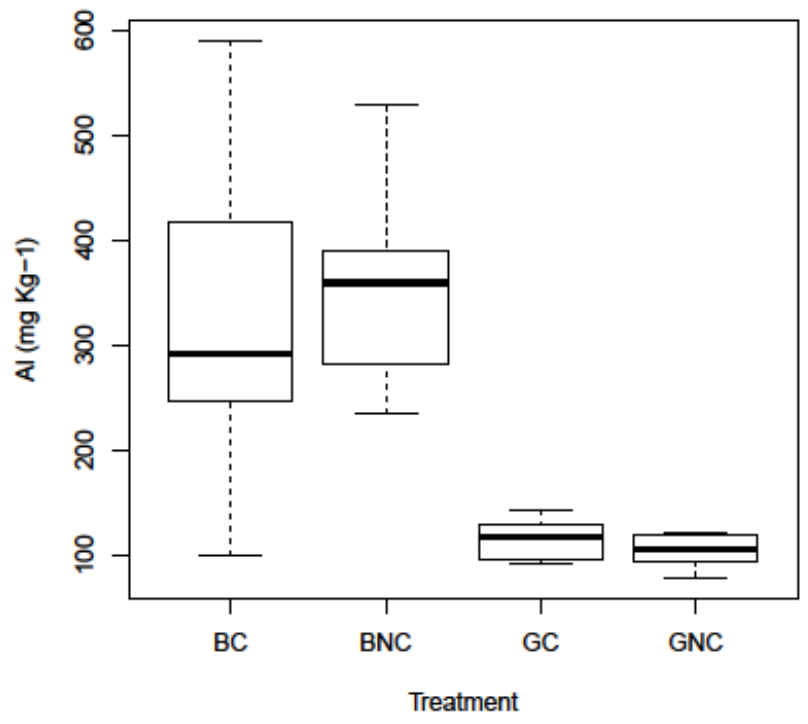

Figure 2-11. Boxplot of Al concentrations in soil samples of four soil treatments at Catenary Coal's Samples mine in Kanawha County, WV. 


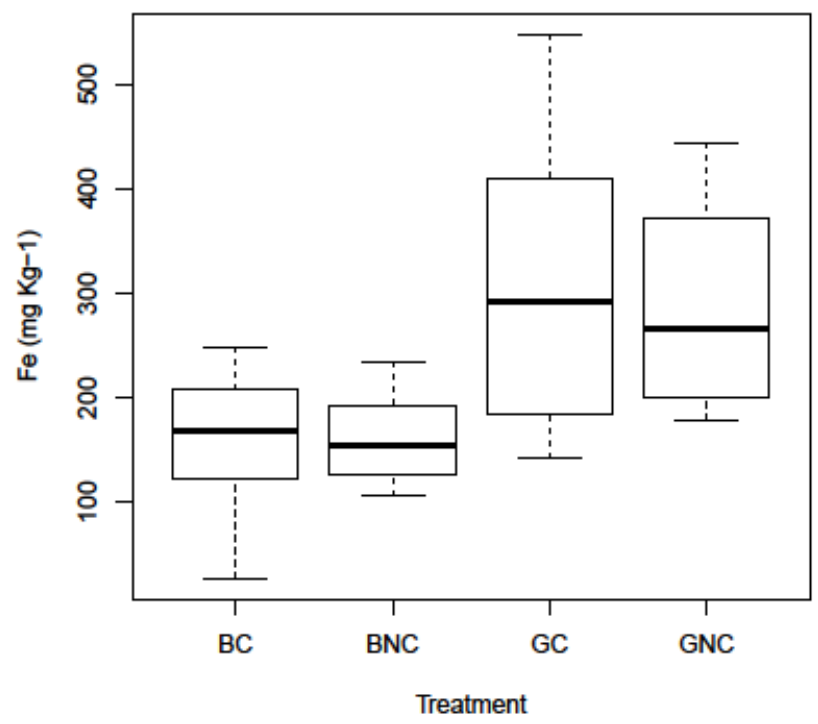

Figure 2-12. Boxplot of Fe concentrations in soil samples of four soil treatments at Catenary Coal's Samples mine in Kanawha County, WV.

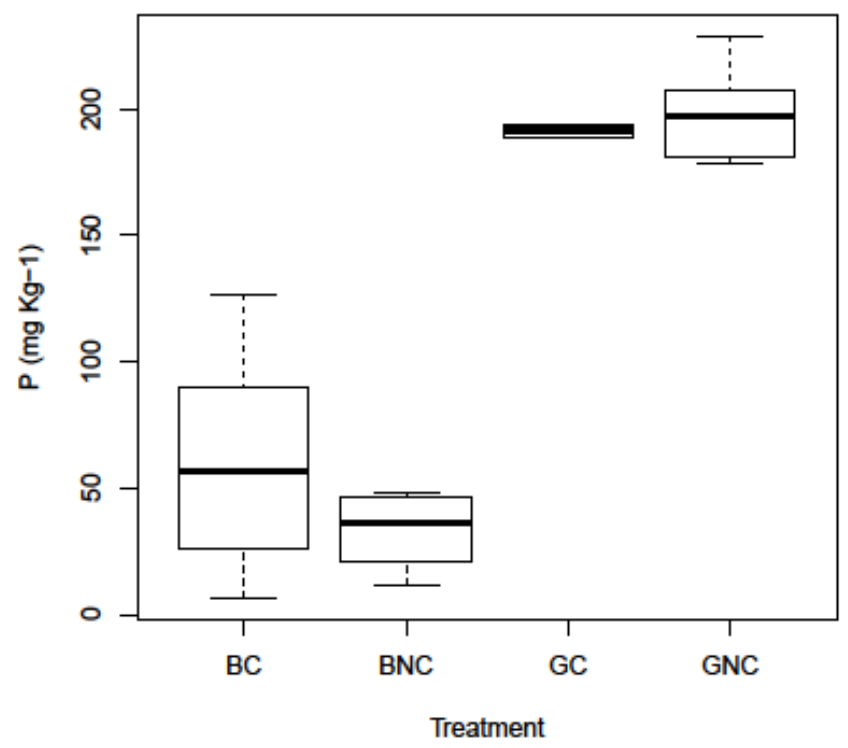

Figure 2-13. Boxplot of $P$ concentrations in soil samples of four soil treatments at Catenary Coal's Samples mine in Kanawha County, WV. 


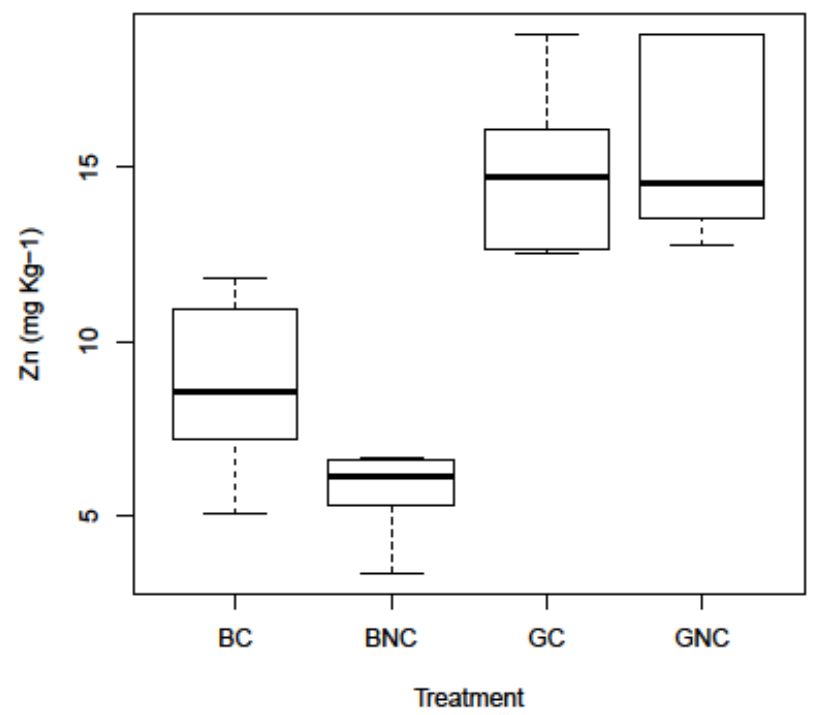

Figure 2-14. Boxplot of $\mathrm{Zn}$ concentrations in soil samples of four soil treatments at Catenary Coal's Samples mine in Kanawha County, WV.

\subsubsection{Ground Cover}

Vegetation and total ground cover in 2011 after seven growing seasons were significantly higher in brown sandstone treatments compared to gray sandstone, and were generally at least 30 times greater (Table 2-11). Compacted weathered brown sandstone treatments had a total average ground cover ranging from 67 to $96 \%$, and non-compacted brown sandstone treatments had a slightly lower range of 56 to $58 \%$ (Table 2-11). Average ground cover for the unweathered gray sandstone treatment was always under 5\%. Conversely, exposed soil and rock cover was significantly higher in unweathered gray sandstone treatments, generally being at least three times greater in unweathered gray sandstone treatments. Both the gray sandstone treatment combinations had very little vegetation cover averaging over $95 \%$ exposed soil and rock at the surface. Only one treatment combination, 1.2-m non-compacted brown sandstone, had standing water present in 2011. 
Table 2-11. Mean ground cover on four soil treatments in 2011 at Catenary Coal's Samples mine in Kanawha County, WV.

\begin{tabular}{lcccccc}
\hline & \multicolumn{6}{l}{ Treatments $\dagger$} \\
\cline { 2 - 7 } Cover type & 4BC & 4BNC & 5BC & 5B-NC & 5GC & 5GNC \\
\hline Herbaceous & $63^{\mathrm{ab}_{\dagger}}-5^{-}$ & $50^{\mathrm{b}}$ & $84^{\mathrm{a}}$ & $49^{\mathrm{b}}$ & $1^{\mathrm{c}}$ & $2^{\mathrm{c}}$ \\
Tree & 5 & 8 & 11 & 8 & 1 & 1 \\
Total & $67^{\mathrm{b}}$ & $58^{\mathrm{b}}$ & $96^{\mathrm{a}}$ & $56^{\mathrm{b}}$ & $2^{\mathrm{c}}$ & $3^{\mathrm{c}}$ \\
& & & & & & \\
Bare/Rock & $32^{\mathrm{b}}$ & $27^{\mathrm{b}}$ & $5^{\mathrm{c}}$ & $38^{\mathrm{b}}$ & $98^{\mathrm{a}}$ & $97^{\mathrm{a}}$ \\
Water & - & 14 & - & 6 & - & - \\
\hline
\end{tabular}

$\dagger$ see Table 2-1 for treatment descriptions

$\$$ means for each cover within rows with the same letter are not significantly different at $\mathrm{P}<0.05$

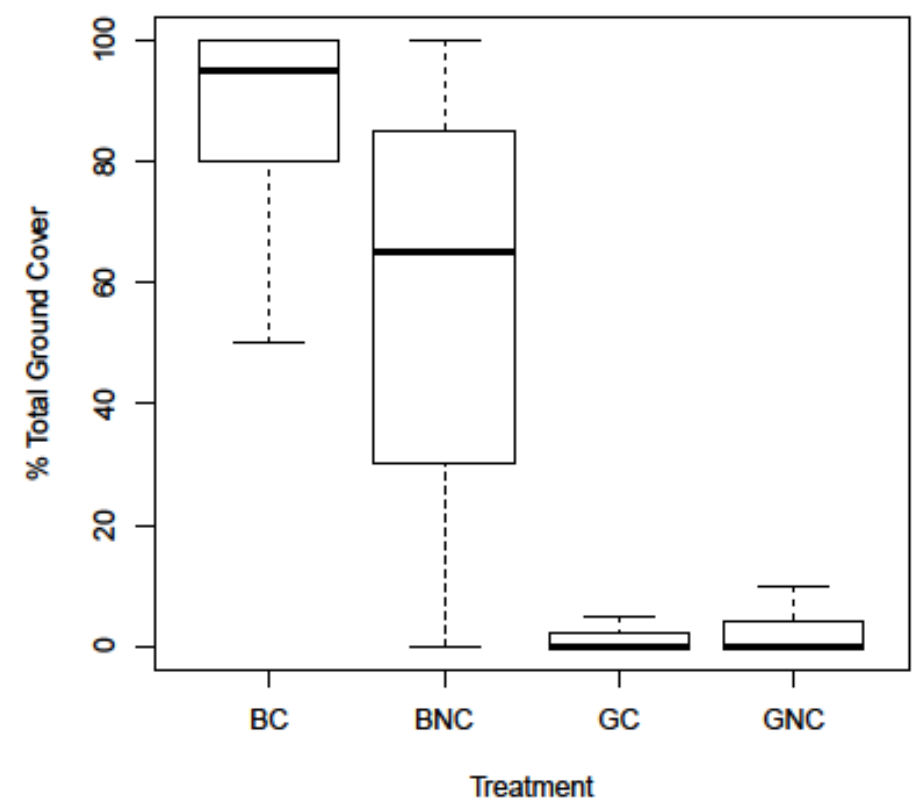

Figure 2-15. Boxplot of total ground cover in 2011 on four soil treatments at Catenary Coal's Samples mine in Kanawha County, WV. 


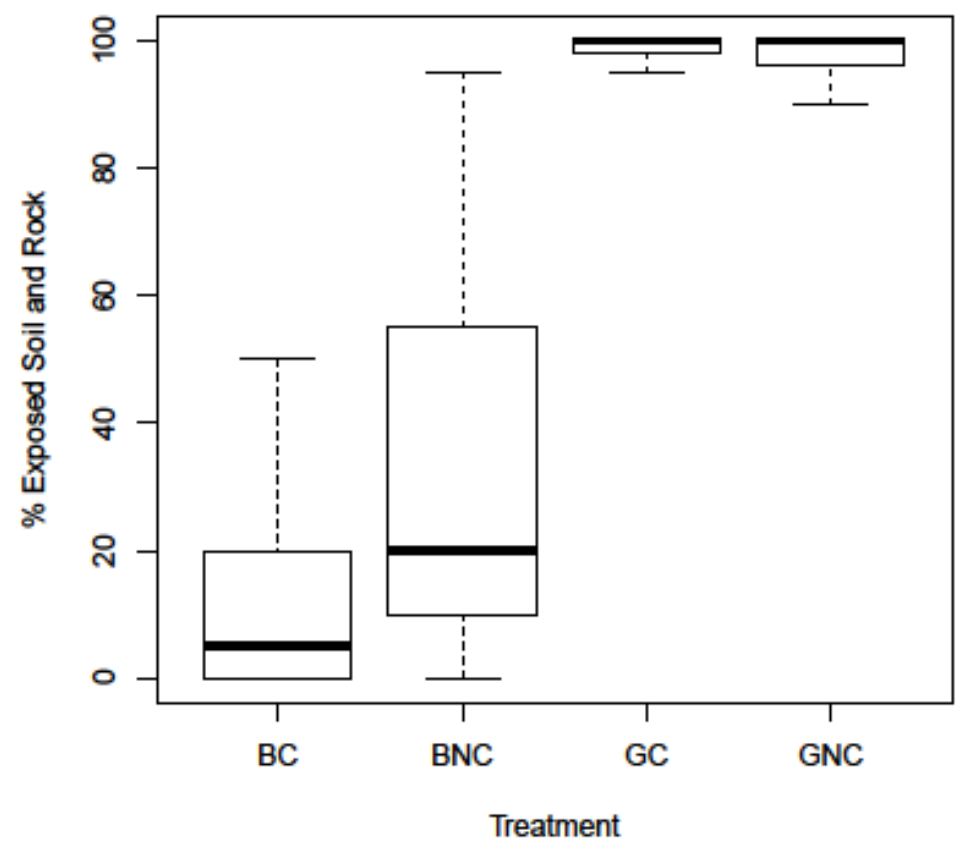

Figure 2-16. Boxplot of exposed soil and rock in 2011 on four soil treatments at Catenary Coal's Samples mine in Kanawha County, WV.

Ground cover of vegetation and exposed soil and rock in unweathered gray sandstone treatments exhibited a narrower range of values compared to weathered brown sandstone treatments (Figures 2-15 and 2-16). Non-compacted weathered brown sandstone treatment had the largest range of values for both cover types.

\subsection{Discussion}

\subsubsection{Trees}

Overall, tree growth in the weathered brown sandstone treatments outperformed those in unweathered gray sandstone treatments. Tree survival across treatments was very similar. Although trees in the unweathered gray sandstone treatments had poor growth, they appeared to be persisting. Compaction was not a significant factor influencing tree growth in this study. 
These trends were consistent throughout the seven growing seasons (Table 2-12) (DeLong, 2010; Emerson et al., 2009). We believe compaction did not fall out as a significant factor because there was a large area of standing water in one transect in the brown uncompacted treatment combination. The trees in this transect were growing very poorly in the water logged substrate.

It is difficult to explain the significance of depth in the brown sandstone plots. We would have expected the $1.2-\mathrm{m}$ plot to have a greater mean volume index because of the standing water found on the 1.5-m plot. The opposite of this was found. The number of individuals occupying each plot was very similar. Further investigation is needed to understand the reasons for these results.

Regarding volume index, previous studies have also reported similar findings. In a study on a surface mine in eastern Kentucky, Angel et al. (2008) found that weathered brown sandstone plots yielded significantly higher tree volumes than gray or gray and brown mixed plots after three years of growth. A greenhouse study by Showalter et al. (2010) reported higher root and shoot biomass for white ash, red oak, and tulip poplar grown in a weathered sandstone versus those grown in unweathered shale and unweathered sandstone. Based on these and other studies, weathered sandstone material has been highly recommended as a topsoil substitute for reforestation reclamation, so long as the material is not highly acidic or contains pyritic materials (Skousen et al., 2011). 
Table 2-12. Mean tree volume index for 2005, 2007, 2009, and 2011 growing seasons in four soil treatments at Catenary Coal's Samples mine in Kanawha, WV.*

\begin{tabular}{ccccccc}
\hline & \multicolumn{5}{c}{ Treatments $\dagger$} \\
\hline Volume & 4BC & 4BNC & 5BC & 5BNC & 5GC & 5GNC \\
2005 & $12^{\mathrm{a}}+-4^{\mathrm{t}}$ & $14^{\mathrm{a}}$ & $11^{\mathrm{a}}$ & $11^{\mathrm{a}}$ & $11^{\mathrm{a}}$ & $15^{\mathrm{a}}$ \\
2007 & $85^{\mathrm{cd}}$ & $181^{\mathrm{a}}$ & $116^{\mathrm{bc}}$ & $159^{\mathrm{ab}}$ & $47^{\mathrm{d}}$ & $45^{\mathrm{d}}$ \\
2009 & $638^{\mathrm{b}}$ & $928^{\mathrm{a}}$ & $414^{\mathrm{bc}}$ & $523^{\mathrm{b}}$ & $190^{\mathrm{cd}}$ & $105^{\mathrm{d}}$ \\
2010 & $981^{\mathrm{ab}}$ & $1065^{\mathrm{a}}$ & $718^{\mathrm{ab}}$ & $649^{\mathrm{b}}$ & $216^{\mathrm{c}}$ & $126^{\mathrm{c}}$ \\
2011 & $1632^{\mathrm{a}}$ & $3685^{\mathrm{a}}$ & $6689^{\mathrm{a}}$ & $2279^{\mathrm{a}}$ & $271^{\mathrm{b}}$ & $262^{\mathrm{b}}$ \\
\hline
\end{tabular}

$\dagger$ see Table 2-1 for treatment descriptions

$\$$ means for each cover within rows with the same letter are not significantly different at $\mathrm{P}<0.05$

* 2005-2009 data from Emerson et al. (2009) and DeLong (2010).

As noted previously, Black locust had the greatest volume index of all species due to characteristics which make it a good pioneer species. Pioneer species are known to volunteer and colonize disturbed sites quickly and invade into adjacent areas. They are frequently planted on disturbed sites because of their ability to assimilate water and nutrients in a variety of soil types and produce exceptional growth under harsh conditions (Huntley, 1990).

Average dogwood volume index was next highest in this study. This species is considered an early to mid-successional tree and helps modify the soil, creating conditions conductive to growth of late successional hardwoods (Burger et al., 2009). Dogwood leaf litter rapidly decomposes, allowing its mineral constituents to become rapidly available to other plants. For this reason it is considered a topsoil improver (Hepting, 1971). It exists and grows well on a variety of soils and tends to do best on well drained flat landscapes with soils ranging in $\mathrm{pH}$ from 6 to 7 (McLemore, 1990). Skousen et al. (2006) found that dogwood voluntarily colonized and grew well on surface mined lands. Many characteristics of the species make it well adapted to 
mine soils and therefore explains why it grew well and better than other species in both sandstone types.

Sugar maple grew poorly in both sandstone types and had the lowest growth of all species planted on the site. Early growth rate of sugar maple is slow (Godman, 1990; Hicks, 1998). Sugar maples are capable of surviving long periods of growth suppression due to environmental factors and will regenerate under heavy shade (Godman, 1990). The species grows best in moist, well-drained loams (Godman, 1965) and this species in West Virginia commonly occurs in areas with high oak site indices (Trimble, 1973). These characteristics suggest that sugar maple may perform better in the future once surrounding trees have grown up around it, improving soil conditions and reducing the amount of direct sunlight resulting in a slightly cooler and moister environment.

Red oak performed better on weathered brown sandstone treatments as indicated by the significantly higher volume index. Its mean volume index overall was the highest of the two oaks at the site. The species is known to be one of the fastest growing native oaks in North America, tolerating a wide range of site characteristics (Hicks, 1998). It grows best on well-drained loam to silty clay loam soils in areas having a north and or north easterly aspects (Ivan, 1990). Its tolerance to a wide range of soil properties could be helpful in explaining why it has persisted in gray sandstone for seven growing seasons with populations comparable to those found in brown sandstone.

White ash attained higher volume index values in weathered brown sandstone treatments and also demonstrated a larger range of values. Skousen et al. (2009) cited white ash for their exceptional survival on surface mined land. In this study, white ash had the highest survival of 
all species. Hawely (1918) describes the species as tolerant to a range of environmental factors and topographic situations. It is most frequently found growing in fertile, moist, moderately welldrained soils with high nitrogen, calcium and sulfur concentrations (Erdmann et al., 1979). It is a pioneer species that will readily volunteer in abandoned fields (Schlesinger, 1990). While capable of growing in low light conditions, white ash seedlings will grow rapidly when exposed to sufficient sunlight becoming nearly intolerant of shade with age (Schlesinger, 1990). Without competition from other trees, white ash will not develop into quality lumber and becomes branchy, but over time shaded branches will drop quickly (Wright, 1965).

White oak is a species considered sensitive to nutrient availability unless grown in sandy soil (Rogers, 1990). The species does well on a variety of sites except in very shallow dry soils (Minckler, 1965), which may explain why volume index for white oak in unweathered gray sandstone was significantly lower than for those individuals growing in weathered brown sandstone. The weathered brown sandstone treatments had some topsoil mixed in which improved soil water retention. While not investigated in this study, it is speculated that gray sandstone dried out more quickly. However, the limited number of plants sampled in the various treatment combinations could have limited the ability to detect significant effects.

Tulip poplar most frequently is found growing in deep, moist soils but is capable of growing well in a variety of soil conditions (Hough, 1936; Hicks, 1998). When growing in its preferred conditions, tulip popular can out-compete most any of its competitors with the exception of white pine. But in poor conditions, tulip poplar is out-competed by trees more suited to the site conditions (Hicks, 1998). In this study, the species performed similarly in both weathered brown and unweathered gray sandstone. 


\subsubsection{Soil}

No soil properties appeared to be significantly affected by compaction in this study. Sandstone type was the major factor responsible for almost all differences among treatment combinations. Soil chemical properties were predictable based on sandstone type. Researchers in the Appalachian region have documented the properties of a variety of mine soils forming from a wide range of mine overburdens. Soils forming in these plots were no exception and have qualities very similar to those documented in past research. A widely accepted generalization is the $\mathrm{pH}$ range of mine soils derived from weathered and unweathered sandstone materials. Weathered sandstone materials typically have a $\mathrm{pH}$ range of 4.5 to 6 , with unweathered sandstones being from 6.5 to 8 (Roberts et al. 1988). Brown and gray treatments in this study had $\mathrm{pH}$ averages that fell within these ranges.

Aluminum concentrations were highest in brown sandstone treatments. Aluminum becomes available at pH less than 5 and less available with increasing pH (Havlin et al., 2005). Brown sandstone derived mine soils have lower $\mathrm{pH}$ falling within the range of higher $\mathrm{Al}$ availability. Also, weathered materials tend to have more Al and Fe oxides (Haering et al., 1993). Conversely, Fe concentrations were significantly higher in gray sandstone than brown sandstone treatments. The higher levels of $\mathrm{Fe}$ in the gray sandstone treatments could result in Fe-P complexes that would prevent future availability of $\mathrm{P}$ for plant uptake (Haering et al., 2004). Like Fe, $\mathrm{P}$ was significantly higher in gray sandstone treatments using Mehlich 1 extraction, but the phosphorus in gray sandstone was not necessarily plant available. Skousen and Emerson (2010) found that the higher extractable P levels in gray sandstone did not translate into higher available $\mathrm{P}$ levels based on leaching tests. In addition to Fe-P complexes at a $\mathrm{pH}$ above 7, $\mathrm{P}$ has 
the tendency to bind to $\mathrm{Ca}$ thereby reducing its availability to plants in these soils with high $\mathrm{Ca}$ concentrations (Klock et al., 1984).

All macro and micro nutrient concentrations significantly decreased between 2005 and 2011 . This was mostly likely a result of weathering. The sandstone derived mine soils have a low cation exchange capacity, potentially leading to future nutrient deficiencies.

\subsection{Conclusion}

In conclusion, after seven growing seasons weathered brown sandstone was found to be a more suitable tree growth medium and topsoil substitute in comparison to unweathered gray sandstone. Average tree volume index was consistently higher for trees grown in the brown sandstone treatments. After seven growing seasons, tree survival was similar among all treatments and tree species between brown and gray sandstone treatments. In this study, compaction was not a significant factor in tree growth. Brown sandstone treatments typically showed a wider range of values for most soil properties, while gray sandstone typically showed a more consistent pattern and more narrow range of values for the same properties. This suggests that brown sandstone weathers more unevenly or is inherently more variable than gray sandstone, resulting in a wider range of site characteristics suitable for a variety of tree species. 


\subsection{References}

Andrews, J.A., J.L. Torbert, J.E. Johnson, and J.A. Burger. 1992. Effects of minesoil properties on young white pine (Pinus strobus) height growth. p. 119-129. In: Proceedings, 9th Annual Meeting American Soc. Mining and Reclamation, 14-18 June, 1992, Duluth, MN.

Andrews, J.A., J.E. Johnson, J.L. Torbert, J.A. Burger, and D.L. Kelting. 1998. Minesoil and site properties associated with early height growth of eastern white pine. J. Environ. Qual. 27:192-199.

Angel, P.N., D.H. Graves, C. Barton, R.C. Warner, P.W. Conrad, R.J. Sweigard, and C. Agouridis. 2006. Surface mine reforestation research: evaluation of tree response to low compaction reclamation techniques. p. 45-58. In: R.I. Barnhisel (ed.), Proc. 7th International Conference on Acid Rock Drainage (ICARD), St. Louis, MO. 26-30 March 2006. American Society of Mining and Reclamation (ASMR). Lexington, KY.

Angel, P.N., C.D. Barton, R.C. Warner, C. Agouridis, T. Taylor, and S.L. Hall. 2008. Forest establishment and water quality characteristics as influenced by spoil type on a loosegraded surface mine in eastern Kentucky. p. 28-65. In: R.I. Barnhisel (ed.), Proc., National Meeting of the American Society of Mining and Reclamation, Richmond, VA. June 14-19. American Society of Mining and Reclamation, Lexington, KY.

Ashby, W.C. 1997. Soil ripping and herbicides enhance tree and shrub restoration on strip mines. Restoration Ecol. 5:169-177.

Burger, J.A., and C.E. Zipper. 2009. How to restore forests on surface mined land. Virginia Coop. Ext. Serv. Publ. no. 460-123, Blacksburg, VA.

Burger, J., D. Graves, P. Angel, V. Davis, and C. Zipper. 2005. The forestry reclamation approach. Office of Surface Mining. Washington, D.C.

Casselman, C.N., T.R. Fox, J.A. Burger, A.T. Jones, and J.M. Galbraith. 2006. Effects of silvicultural treatments on survival and growth of trees planted on reclaimed mined land in Appalachians. For. Ecol. and Management. 223:403-414

Clayton, J.L, G. Kellog, N. Forester. 1987. Soil disturbance- tree growth raltaions in central Idaho clearcuts. USDA Forest Service Note INT-372. USDA Forest Service Intermountain Forest Experiment Station, UT.

Cleveland, B. and R. Kjelgren. 1994. Establishment of six tree species on deep-tilled minesoil during reclamation. For. Ecol. Manage. 68, pp. 273-280.

Daniels, W.L. and D.F. Amos. 1985. Generating productive topsoil substitutes from hard rock overburden in the southern Appalachians. Env. Geochem. \& Health. 7:8-15. 
DeLong, C. 2010. Evaluation of reforestation efforts on two reclaimed surface mines in West Virginia. M.S. Thesis, West Virginia University, Morgantown, WV.

Emerson, P., J. Skousen, and P. Ziemkiewicz. 2009. Survival and growth of hardwoods in brown versus gray sandstone on a surface mine in West Virginia. J. Environ. Qual. 38:18211829

Erdmann, G. G., F.T. Metzger, and R.R. Oberg. 1979. Macronutrient deficiency symptoms in seedlings of four northern hardwoods. USDA Forest Service, General Technical Report NC-53. North Central Forest Experiment Station, St. Paul, MN. 36 pp.

Geyer, W.A. 1972. Timber growth on graded and ungraded strip-mine spoil banks in southeast Kansas. Transactions of the Kansas Academy of Science. 74:318-324.

Godman, R.M. 1965. Sugar maple (Acer saccharum Marsh.) In: Silvics of forest tress of the United States. p 66-76. U.S. Department of Agriculture Handbook 271. Washington, DC.

Godman, R.M., H.W. Yawney, and C.H. Tubbs. 1990. Acer saccharum Marsh., sugar maple. In: Silvics of North America, Vol. 2, Hardwoods, R.M. Burns and B.H. Honkala (eds.) USDA For. Serv. Agric. Handb. 654:78-91.

Grube, W.E., R.M. Smith, and J.T. Ammons. 1982. Mineralogical alterations that affect pedogenesis in minesoils from bituminous overburdens. p. 209-225. In J.A. Kittrick et al. (ed.) Acid sulfate weathering. SSSA Spec. Publ. 10. SSSA, Madison, WI.

Havlin, J.L, J.D.Beaton, S.L.Tisdale, and W.L.Nelson. 2005. Soil fertility and fertilizers. Pearson Education, Inc. Upper Saddle River, NJ. 515 pp.

Haering, K.C., W.L. Daniels, and J.A. Roberts. 1993. Changes in mine soil properties resulting from overburden weathering. J. Environ. Qual. 22:194-200.

Haering, K.C., W.L. Daniels, and J.M. Galbraith. 2004. Appalachian mine soil morphology and properties: effects of weathering and mining method. Soil Sci. Soc. Am. J. 68:1315-1325.

Hawley, R.C. and A.F. Hawes.1918. Silvicultural characteristics of important new England tress. In: Forestry in New England. Stanhope Press. Boston, MA. 281 pp.

Heilman, P. 1981. Root penetration of Douglas-fir seedlings into compacted soil. Forest Science. 27:660-666.

Hepting, G.H. 1971. Diseases of forest ad shade trees of the United States. U.S. Department of Agriculture, Agriculture Handbook 386. Washington, DC. p658.

Hicks, R.R. Jr. 1998. Ecology and management of central hardwood forests. Wiley, New York, USA. 368pp. 
Huntley, J. C.. 1990. Robinia pseudoacacia L. Black Locust. In: Silvics of North America, Vol. 2, Hardwoods, R.M. Burns and B.H. Honkala (eds.) USDA For. Serv. Agric. Handb. 654:605-613.

Hough, R.B. 1936. Handbook of the trees of the northern states and Canada east of the Rocky Mountains. Romeyn B. Hough Company, Lowville, NY. 470 pp.

Ivan, S.L. 1990. Quercus rubra L., flowering dogwood. In: Silvics of North America Vol. 2, Hardwoods, R.M. Burns and B.H. Honkala (eds.) USDA For. Serv. Agric. Handb. 654:727-733.

Klock, G.O., R.G. Cline, and D.N. Swanston. 1984. Geology and Soils. p. 65-96. In:.K. F. Wenger (ed.) Forestry Handbook. Vol. 2.

Lockaby, B.G. and C.G. Vidrine. 1984. Effect of logging equipment traffic on soil density and growth and survival of young loblolly pine. Soc. J. Am. For. 8:109-112.

McFee, W.W., W.R. Byrnes, J.G. Stockton. 1981. Characteristics of coal mine overburden important to plant growth. J. Environ. Qual. 10:300-308.

McLemore, B.F. 1990. Cornus florida L., flowering dogwood. In: Silvics of North America Vol. 2, Hardwoods, R.M. Burns and B.H. Honkala (eds.) USDA For. Serv. Agric. Handb. 654:279-283.

Minckler, L. S. 1965. White oak (Quercus alba L.) In Silvics of forest trees of the United States. p 632-367. H.A. Fowells, comp. U.S. Department of Agriculture, Agriculture Handbook 271, Washington D.C.

Philo, G.R., C.A, Kolar, W.C. Ashby. 1982. Effects of ripping on mine soil compaction and black walnut establishment. In: Proceedings, Symposium on Surface Mining Hydrology, Sedimentology, and Reclamation, Lexington, KY, 1-3 Nov 1982.

R Development Core Team. 2011. R: A language and environment for statistical computing, reference index version 2.13.0. R Foundation for Statistical Computing, Vienna, Austria. ISBN 3-90051-08-9, URL http://www.R-project.org.

Roberts, J.A., W.L. Daniels, J.C. Bell, and J.A. Burger. 1988. Early stages of mine soil genesis in a southwest Virginia spoil lithosequence. Soil Sci. Soc. Amer. J. 52:716-723.

Rodrigue, J.A. and J.A. Burger. 2004. Forest Soil productivity of mined land in the Midwestern and Eastern coalfield regions. Soil Sci. Soc. Am. J. 68:833-844.

Rogers, R. 1990. Quercus alba L., white oak. In: Silvics of North America, Vol. 2, Hardwoods, R.M. Burns and B.H. Honkala (eds.) USDA For. Serv. Agric. Handb. 654:605-613. 
Schlesinger, R.C. 1990. Fraxinus americana L., white ash. In: Silvics of North America, Vol. 2, Hardwoods, R.M. Burns and B.H. Honkala (eds.) USDA For. Serv. Agric. Handb. 654:333-338.

Showalter, J.M., J.A. Burger, and C.E. Zipper. 2010. Hardwood seedling growth on different mine spoil types without and with topsoil amendment. J. Environ. Qual. 39:483-491.

Skousen, J., and P. Emerson. 2010. Release of nutrients from brown and gray sandstone soil substitutes in southern West Virginia. p. 1135-1143. In: Proceedings, 2010 National Meeting of the American Society of Mining and Reclamation, Pittsburgh, PA, June 5-11, 2010. ASMR, Lexington, KY.

Skousen, J., J. Gorman, E. Pena-Yewtukhiw, J. King, J. Stewart, P. Emerson, and C. DeLong. 2009. Hardwood tree survival in heavy ground cover on reclaimed land in West Virginia: mowing and ripping effects. J. Environ. Qual. 38: 1400-1409.

Skousen, J., P. Ziemkiewicz, and C. Venable. 2006. Tree recruitment and growth on 20-yr-old, unreclaimed surface mined lands in West Virginia. International J. Mining, Reclamation and Environment 20(2): 142-154.

Skousen, J., and C. Zipper. 2010. Powell River Project - Revegetation species and practices. Virginia Cooperative Extension 460-122, Blacksburg, VA. http://pubs.ext.vt.edu/460/460-122/460-122.html

Skousen, J., C. Zipper, J. Burger, C. Barton, and P. Angel. 2011. Selecting materials for mine soil construction when establishing forests on Appalachian mine sites. Forest Reclamation Advisory No. 8, July 2011, Appalachian Regional Reforestation Initiative. http://arri.osmre.gov/

Stroo, H.F., and E.M. Jencks. 1982. Enzyme activity and respiration in minesoils. Soil Sci. Soc. Am. J. 46:548-553.

Tschaplinski, T., G. Tuskan, G. Michael Gebre, and D. Todd. 1998. Drought resistance of two hybrid Populus clones grown in a large-scale plantation. Tree Physiology 18: 653-658

Trimble, G. P. Jr. 1973. The regeneration of central Appalachian hardwoods with emphasis on the effects of site quality and harvesting practice. USDA Forest Service. Research Paper NE-282. Northeastern Forest Experiment Station, Upper Darby, PA. p14.

Torbert, J.L., and J.A. Burger. 2000. Forest land reclamation. p. 371-398. In Reclamation of drastically disturbed lands. (eds R.I. Barnhisel, R.G. Darmody, and W.L. Daniels). American Society of Agronomy, Madison, WI.

Torbert, J.L., A.R. Tuladhar, J.A. Burger, and J.C. Bell. 1988. Minesoil property effects on the height of 10-year-old white pine. J. Environ. Qual. 17:189-192. 
Wolf, B. 1994. Soil survey of Boone County, West Virginia. USDA, Soil Conservation Service, Morgantown, WV. 115 pp.

Wright, J. W. 1965. White ash (Fraxinus americana L.) in Slivics of forest trees of the United States. P 191-196. H.A. Fowells, comp. U.S. Department of Agriculture, Agriculture Handbook 271, Washington D.C.

Zeleznik, J., and J. Skousen. 1996. Survival of three tree species on old reclaimed surface mines in Ohio. J. Environ. Qual. 25:1429-1435.

Zipper, C., J. Burger, J. Skousen, P. Angel, C. Barton, V. Davis, and J. Franklin. 2011. Restoring forests and associated ecosystem services on Appalachian coal surface mines. Environ. Management 47:751-765. 


\section{Birch River Mine}

\subsection{Literature Review and Objectives}

Competition from ground cover is a critical factor determining the outcome of forestry land use success. Past hydroseeding practices, implementing heavy rates of seeding with aggressive non-native Lespedeza (Lespedeza cuneata L.) and Kentucky-31 tall fescue (Festuca arundinacea L.) and heavy fertilization, were popular in early vegetation applications (Torbert and Burger, 2000). This combination of reclamation practices provided rapid, thick, and consistent ground cover. In a forestry reclamation setting, this type of ground cover grows too fast and competes too fiercely for nutrients, light, and water resources. When used in forestry, grain-producing forage crops further reduce tree survival by attracting rodents that will also feed on seedlings while girdling the stems (Burger et al., 2002; Skousen et al., 2009). It is necessary for some ground cover to be planted to stabilize soils. However this ground cover must have little effect on the establishment and growth of young tree seedlings. Tree-compatible ground covers are grasses and legumes that can provide soil stability through rapid germination but have a slow, sprawling growth habit so they do not over grow trees and prevent adequate lighting conditions (Torbert and Burger, 2000). In addition, ground cover species must tolerate mine soil characteristics and improve mine soil properties through such mechanisms as microbial growth, nitrogen fixation, and release and uptake of nutrients. These compatible species must be seeded at a low rate, 10 to $20 \mathrm{~kg} \mathrm{ha}^{-1}$, with less nitrogen fertilizer (Burger et al., 2005).

Conditions such as those mentioned above provide additional benefits by allowing native species to volunteer and germinate from native seed banks adjacent to plots and those found in salvaged original topsoil reapplied during reclamation (Burger et al., 2005; Holl et al., 2001; Showalter et al., 2010; Skousen et al., 2006). Decreased vegetation has been shown to result in 
greater success of tree survival and growth (Burger et al., 2009; Chaney et al., 1995, King and Skousen, 2003, Rizza et al., 2007)

Bark mulch waste products from sawmill and timbering operations could have a place in mine reclamation. These wastes (bark, wood shavings, and sawdust) accumulate on log landings and are mixed with limestone gravel and soil. They typically end up in landfills. However, these materials could potentially help reclamation efforts (Falk, 1997). Disturbed soils often lack organic material, a soil component that aids in reduction of bulk density, increases water infiltration and increases soil stability through aggregation (Insam and Domsch, 1988). All of these result in the reduction of soil erosion and prevention of water loss and could help to promote healthy plant growth. Norland (2000) suggests that mulch benefits mine soil with respect to the above mentioned properties. Addition and subsequent decomposition of bark mulch may help to restore organic matter over time and ameliorate the negative impacts of disturbance on mine soils. Other types of organic mulches have been found to improve soil characteristics related to soil organic matter (Anderson et al., 2008; Wick et al., 2010). Studies by Ringe (1988 and 1989) determined that the added expense of applying bark mulch is more than offset by increased tree survival and growth.

In this study, we investigated the effects of mulching, hydroseeding, and sandstone type on hardwood tree growth. Our main objective was to evaluate tree growth as a result of all combinations of these factors. We have also examined soil properties related to these treatments.

The objectives of this study were to determine tree growth and survival on weathered brown and unweathered gray sandstone substrates, amended and not amended with herbaceous ground 
cover and bark mulch treatments; and to evaluate soil physical and chemical properties as a result of these amendments.

\subsection{Methods}

\subsubsection{Study Area}

Arch Coal's (formerly International Coal Group) Birch River Operation is located near Cowen in Webster County, West Virginia, approximately $100 \mathrm{~km}$ northeast of Charleston. Approximately 1,620 ha of contiguous area are potentially minable by surface methods. Coal from the Upper and Middle Kittanning, Upper and Lower Clarion, Stockton and Coalburg seams are currently being mined. Overburden was moved from above the seams by shovels, front end loaders, bulldozers, trucks, and, until November 2009, by dragline. The vegetative cover on premining land was a mixed hardwood forest. Gilpin and Gilpin-Dekalb series (Typic Hapludults) were the pre-existing soil types on the moderate to steep slopes of the region.

In November 2006, a 5-ha plot was created using two types of sandstone overburden. Half of the area was constructed with weathered brown sandstone, the other half with unweathered gray sandstone. Overburden materials were end-dumped into conjoining piles that were approximately 1.5-m deep throughout. To limit compaction, a bulldozer made only one pass over the piles to strike off the tops, resulting in approximately $1.2-\mathrm{m}$ depth of rough graded material throughout the plot. In April 2007, a 15-cm deep layer of bark mulch was applied to a strip down the center of the plot which included portions of both sandstone types (Figure 3-1). Following mulch application, approximately 8,000 2-0 bare root seedlings were planted on 2.4m-centers by a professional planting crew. A list of tree species and their respective portions of the total are in Table 3-1. The following fall, ends of the plot were hydroseeded with a seed mix of compatible 
herbaceous species (Table 3-2), and fertilized at a rate of $336 \mathrm{~kg} \mathrm{ha}^{-1}$ of 10-20-10 NPK. The treatments are found in Table 3-3.

Table 3-1. Species and number of trees planted at the Birch River Operation in Webster County, WV.

\begin{tabular}{lll}
\hline Species & $\begin{array}{l}\text { Total Number } \\
\text { Planted }\end{array}$ & $\begin{array}{l}\text { \% of Total } \\
\text { Planted }\end{array}$ \\
\hline Black cherry (Prunus serotina Ehrh.) & 850 & 11 \\
Northern red oak (Quercus rubra L.) & 850 & 11 \\
Sugar maple (Acer saccharum Marsh.) & 850 & 11 \\
White ash (Fraxinus americana L.) & 850 & 11 \\
White oak (Quercus alba L.) & 850 & 11 \\
Black locust (Robinia pseudoacacia L.) & 800 & 10 \\
Pitch X loblolly pine (Pinus rigida x taeda) & 800 & 10 \\
Tulip poplar (Liriodendron tulipifera L.) & 600 & 8 \\
Sycamore (Platanus occidentalis L.) & 450 & 6 \\
White pine (Pinus strobus L.) & 400 & 5 \\
Gray dogwood (Cornus racemosa Lam.) & 350 & 4 \\
Eastern redbud (Cercis Canadensis L.) & 350 & 4 \\
\hline Total & $\mathbf{8 , 0 0 0}$ & $\mathbf{1 0 0}$ \\
\hline
\end{tabular}

Table 3-2. Species and rate of ground cover hydroseeded at the Birch River Operation in Webster County, WV.

\begin{tabular}{ll}
\hline Species & Rate \\
\hline & $\mathrm{kg} \mathrm{ha}^{-1}$ \\
Birdsfoot trefoil (Lotus corniculatus L.) & 11.2 \\
Kobe lespedeza (Kummerowia stipulaceea Maxim.) & 5.6 \\
Ladino clover (Trifolium repens L.) & 3.4 \\
Orchard grass (Dactylis glomerata L.) & 5.6 \\
Perennial ryegrass (Lolium perenne L.) & 5.6 \\
Redtop (Agrostis gigantea L.) & 2.2 \\
Weeping lovegrass (Eragrostis curvula Schra.) & 2.2 \\
\hline Total & $\mathbf{3 5 . 8}$ \\
\hline
\end{tabular}


Table 3-3. Soil treatment combinations at the Birch River Operation in Webster County, WV.

\begin{tabular}{ll}
\hline Treatment & Abbreviation \\
\hline weathered brown sandstone & B \\
weathered brown sandstone w/bark mulch & BM \\
weathered brown sandstone w/hydroseeding & BH \\
weathered brown sandstone w/bark mulch and w/hydroseeding & BMH \\
unweathered gray sandstone & G \\
unweathered gray sandstone w/bark mulch & GM \\
unweathered gray sandstone w/hydroseeding & GH \\
unweathered gray sandstone w/bark mulch and w/hydroseeding & GMH \\
\hline
\end{tabular}
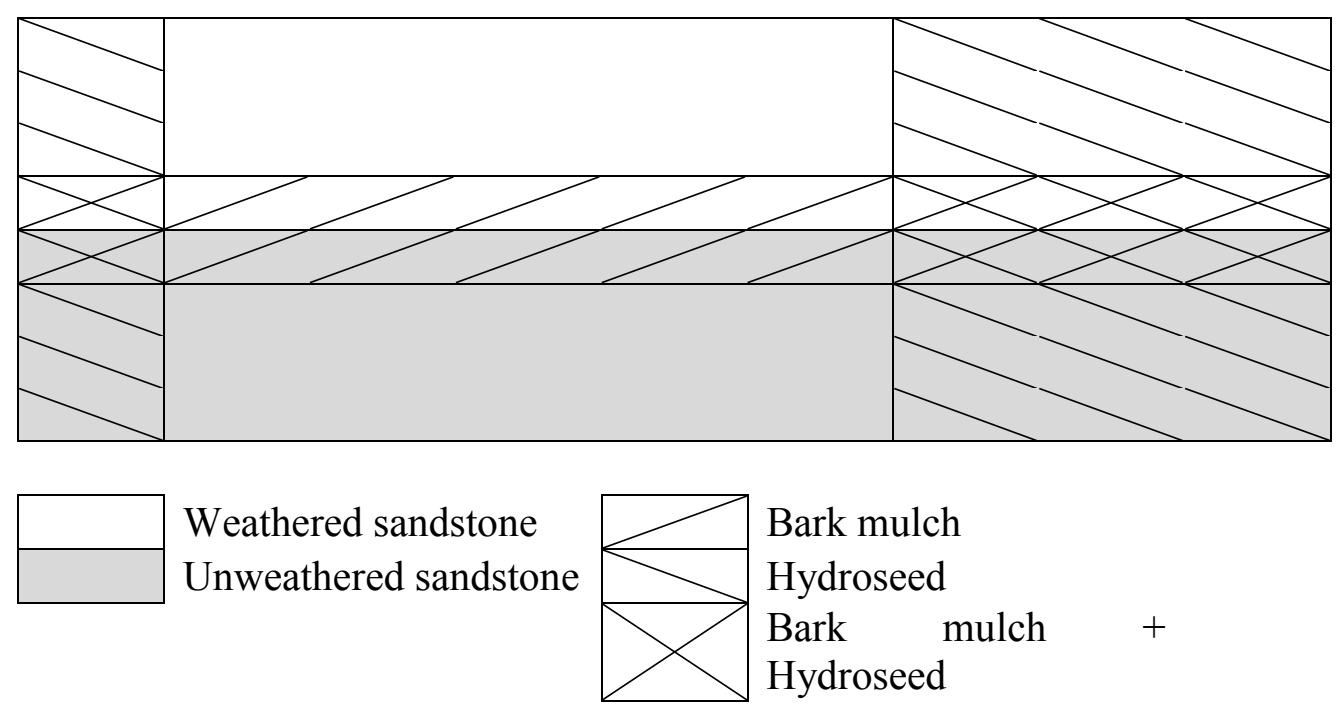

Bark mulch

Hydroseed

Bark mulch + Hydroseed

\section{Figure 3-1. Simplified diagram of treatment layout at the Birch River Operation in Webster County, WV. Not to scale.}

\subsubsection{Trees}

To assess tree growth, we established eleven $3 \mathrm{~m}$-wide transects varying in length in order to span the width of the entire 5-ha plot. These same transects were used every year for tree and soil sampling since 2008. Height to highest live growth and stem diameter $1 \mathrm{~cm}$ above the soil surface was recorded for every tree within all transects. Data collections occurred during August of every year from 2008 to 2011 . Volume index in $\mathrm{cm}^{3}$ was used as an indicator of tree growth. 
Volume index was calculated with the following equation (Emerson, et al., 2009; Angel et al., 2008; Tschaplinski et al., 1998):

Tree volume index $\left(\mathrm{cm}^{3}\right)=$ Height $(\mathrm{cm}) \times \operatorname{Diameter}^{2}\left(\mathrm{~cm}^{2}\right)$

Tree survival was calculated by finding the difference between the number of trees sampled the first year, 2008, and the last year, 2011.

\subsubsection{Soil}

The top $15 \mathrm{~cm}$ of soil from the surface was collected from four random locations within transects of each treatment combination in July of 2007 to 2010 (DeLong, 2010). In mulched areas, we sampled the mineral soil by scraping aside the bark mulch on the surface of the soil. In July 2011, the sampling regime was altered. Three samples were collected and composited from each experiment unit. An experimental unit is a treatment combination found in one transect. There are a total of 36 experimental units at this study site. These samples were used for chemical and physical analysis.

Soils were air dried and sieved through a $2 \mathrm{~mm}$ screen to separate the fine fraction $(<2 \mathrm{~mm})$ from the coarse or rock fraction ( $\geq 2 \mathrm{~mm})$. The fine soil fraction was used for chemical analysis.

Extractable elements were determined using a Mehlich 1 extraction solution. Five grams from the fine fraction of each sample were placed in 45-mL polypropylene centrifuge tubes with $25 \mathrm{~mL}$ of Mehlich 1 extracting solution $\left(0.05 \mathrm{M} \mathrm{HCl}\right.$ and $\left.0.025 \mathrm{M} \mathrm{H}_{2} \mathrm{SO}_{4}\right)$. Supernatant was analyzed for phosphorus, calcium, magnesium, potassium, aluminum, iron, manganese, and zinc using a Perkin Elmer Plasma 400 emission spectrometer. 
Soil $\mathrm{pH}$ was measured in a 1:2 mixture of 5 grams of soil and $10 \mathrm{~mL}$ of deionized water. Soluble salts, as determined by electrical conductivity, were measured on a 1:1 mixture consisting of 5 grams soil and $5 \mathrm{~mL}$ deionized water.

\subsubsection{Data Analysis}

We constructed five general linear models, representing working hypothesis of treatment factors to predict tree volume index. Each linear model contained one dependent variable (volume index) and one independent variable (a treatment or the interaction of two treatments) We used Akaike's Information Criterion (AIC) to compare the fit of each model to the data. AIC also allows candidate models to be ranked, something particularly useful for making management recommendations. The five linear models selected to predict volume index were (1) sandstone type only (SS), (2) mulch application only (M), (3) hydroseeding only (H), (4) an interaction of sandstone type and mulch application (SS*M), (5) an interaction of sandstone type and hydroseeding $\left(\mathrm{SS}^{*} \mathrm{M}\right)$, and (6) a model fitting all data to an intercept only, which is independent of treatment (I). This last model, I, represents the hypothesis that no treatment was useful in predicting tree volume index. Models that ranked lower than the last model, I, were not likely responsible for explaining trends or differences in the data. Delta AIC values that corrected for sample size bias $(\triangle \mathrm{AICc})$ were used to rank models and the model weight was used to evaluate the ability of the model to correctly predict volume index (Burnham and Anderson, 2002). No tree species was represented in all treatment combinations. Therefore, volume index was calculated for all trees in each treatment combination because volume data for individual tree species were unavailable for a comparison across treatments. Box plots were used to examine trends in the data. 
The same working models were used to evaluate the influence of treatment on tree survival. We calculated survival by the difference of individuals occupying experimental units between 2008 and 2011. Trees volunteering on the site were not used in the analysis.

Finally, we performed PCA on standardized data to summarize the dominant trends. Data were transformed if needed to meet normality assumptions. One of the pair of redundant variables was excluded if correlation analyses showed an $r>0.95\left(r^{2}>0.90\right)$. Principle components with eigenvalues $>1.0$ were considered significant and variables with factor loadings $>0.6$ were considered highly influential. We then created regression models to explain these factors from the experimental conditions on the site, and we evaluated their likelihood as above. The six general linear models for predicting selected soil chemical properties were (1) sandstone type only (SS), (2) mulch application only (M), (3) hydroseeding only (H), (4) an interaction of sandstone type and mulch application $\left(\mathrm{SS}^{*} \mathrm{M}\right),(5)$ an interaction of sandstone type and hydroseeding $\left(\mathrm{SS}^{*} \mathrm{H}\right)$, and (6) a model independent of treatment (I). We used the R language and Environment for Statistical Computing for all the above analyses (R Development Core Team, 2011).

\subsection{Results}

\subsubsection{Trees}

In 2008, model I (no treatment) ranked the highest of the model sets for predicting tree volume index (Table 3-4). With an AICc weight of 0.4 , the I model had two times more empirical support to predict tree volume index than the next model. Models using hydroseeding $(\mathrm{H})$, mulch application $(\mathrm{M})$, and sandstone type (SS) alone to predict tree volume ranked below the I model with AICc weights of 0.19 to 0.14 . The interaction models (SS*M and SS*H) ranked 
at the bottom, both with AICc weights of 0.05 . The ranking and weights of these models indicated that no treatment predicted tree volume the first year after tree planting. Treatments did not yet have a strong influence on growth and were unable to predict volume index, but they did have a slight influence according to the AICc weights of the treatment models.

One year later, the sandstone type and mulch application interaction model (SS*M) ranked the highest in the set of models, closely followed by the SS model with AICc weights of 0.48 and 0.36 , respectively (Table 3-4). The sandstone type and hydroseeding interaction model $(\mathrm{SS} * \mathrm{H})$ ranked third with an AICc weight of 0.15, having less than half the empirical support of the second-ranked model (SS) and a third of the support for the SS*M model. Although the interaction model $(\mathrm{SS} * \mathrm{M})$ had the highest support in predicting tree volume index, mulch application alone was not able to do the same. Mulch (M) had no empirical support for predicting volume index and ranked below the I model, indicating it had less influence on tree growth in 2009. The same can be said for the H model.

In 2010, a similar trend was seen as in the previous year. The SS*M model ranked the highest, but the AICc weight more than doubled resulting in a value of 0.92 (Table 3-4). This top ranked model had 18 times more empirical support to predict tree volume index than the next ranked models, SS and M with AICc weights of 0.05 and 0.02 , respectively. Sandstone and mulch were both important in predicting tree volume index but their interaction was more influential on volume index than either independent of the other. All other models had AICc weights of 0 indicating they were unable to predict tree volume index and therefore had little influence on tree growth in 2010. 
The following year's AIC analysis yielded results similar to 2010. In 2011, the model ranking was the same, with the exception of models containing hydroseed application. Both of these models, $\mathrm{H}$ and $\mathrm{SS} * \mathrm{H}$, where ranked below the I model. AICc weight for the top ranked model, SS*M, was 0.72 , followed by SS with a weight of 0.13 and $\mathrm{M}$ with a weight of 0.10 . Again, the interaction of $\mathrm{SS} * \mathrm{M}$ was much greater in predicting tree volumes than either sandstone and mulch alone. There was little empirical support for models containing the hydroseed treatment. AICc values and ranking for these models indicated they had little to no ability in predicting tree volume index and therefore most likely had little influence on tree growth in 2011. 
Table 3-4. Model ranking using AIC for volume index of trees planted at the Birch River Operation in Webster County, WV.

\begin{tabular}{llllllll}
\hline Year & Model & K & AICc & AAICc & AICcWt & Cum.Wt & LL \\
\hline 2008 & I & 2 & 5452.75 & 0 & 0.40 & 0.4 & -2724.36 \\
& H & 3 & 5454.23 & 1.48 & 0.19 & 0.59 & -2724.09 \\
& M & 3 & 5454.37 & 1.62 & 0.18 & 0.77 & -2722.16 \\
& SS & 3 & 5454.91 & 2.16 & 0.14 & 0.9 & -2722.39 \\
& SS*M & 4 & 5456.96 & 4.2 & 0.05 & 0.95 & -2722.39 \\
& SS*H & 4 & 5456.96 & 4.21 & 0.05 & 1 & -2722.39 \\
\hline 2009 & SS*M & 4 & 7206.19 & 0 & 0.48 & 0.48 & -3599.05 \\
& SS & 3 & 7206.79 & 0.6 & 0.36 & 0.84 & -3600.37 \\
& SS*H & 4 & 7208.55 & 2.36 & 0.15 & 0.99 & -3600.23 \\
& I & 2 & 7215.35 & 9.16 & 0 & 0.99 & -3605.66 \\
& M & 3 & 7215.43 & 9.24 & 0 & 1 & -3604.69 \\
& H & 3 & 7216.84 & 10.64 & 0 & 1 & -3605.39 \\
\hline 2010 & SS*M & 4 & 8547 & 0 & 0.92 & 0.92 & -4269.46 \\
& SS & 3 & 8552.66 & 5.66 & 0.05 & 0.98 & -4273.3 \\
& M & 3 & 8554.56 & 7.57 & 0.02 & 1 & -4273.24 \\
& SS*H & 4 & 8562.49 & 15.49 & 0 & 1 & -4278.22 \\
& I & 2 & 8564.1 & 17.1 & 0 & 1 & -4280.04 \\
& H & 3 & 8566.03 & 19.03 & 0 & 1 & -4279.99 \\
\hline 2011 & SS*M & 4 & 8422.6 & 0 & 0.72 & 0.72 & -4206.24 \\
& SS & 3 & 8426.08 & 3.48 & 0.13 & 0.85 & -4209 \\
& M & 3 & 8426.63 & 4.02 & 0.10 & 0.94 & -4208.25 \\
& I & 2 & 8429.41 & 6.81 & 0.02 & 0.97 & -4212.69 \\
& SS*H & 4 & 8429.63 & 7.03 & 0.02 & 0.99 & -4211.79 \\
& H & 3 & 8431.26 & 8.65 & 0.01 & 1 & -4212.6 \\
\hline & & & & & & &
\end{tabular}

Examining the boxplots of tree volume indices for sandstone and mulch treatment combinations illustrates the impact these treatments had on tree growth from 2009 to 2011 (Fig 3-2). In 2009, there was a considerable amount of overlap between interquartile ranges of treatment combinations. Gray sandstone amended with mulch appeared to have a wider range of tree volume index more comparable to brown sandstone without mulch than gray sandstone without mulch. The same trend was seen in 2010 and 2011. Tree volume indices in areas of gray sandstone without mulch did not reach the values of those in the other three treatment 
combinations. The highest mean tree volume index, $1153 \mathrm{~cm}^{3}$, was found in brown sandstone mulch treatment combinations (Table 3-5). Areas of gray sandstone with mulch had a tree volume index of $729 \mathrm{~cm}^{3}$ which was comparable to all brown sandstone treatments. The lowest tree volume index for brown sandstone, $664 \mathrm{~cm}^{3}$, was found in brown hydroseeded areas. The lowest mean tree volume indices were found in treatments of gray sandstone without mulch amendment: $98 \mathrm{~cm}^{3}$ in gray sandstone alone and $64 \mathrm{~cm}^{3}$, in gray sandstone hydroseeded areas.
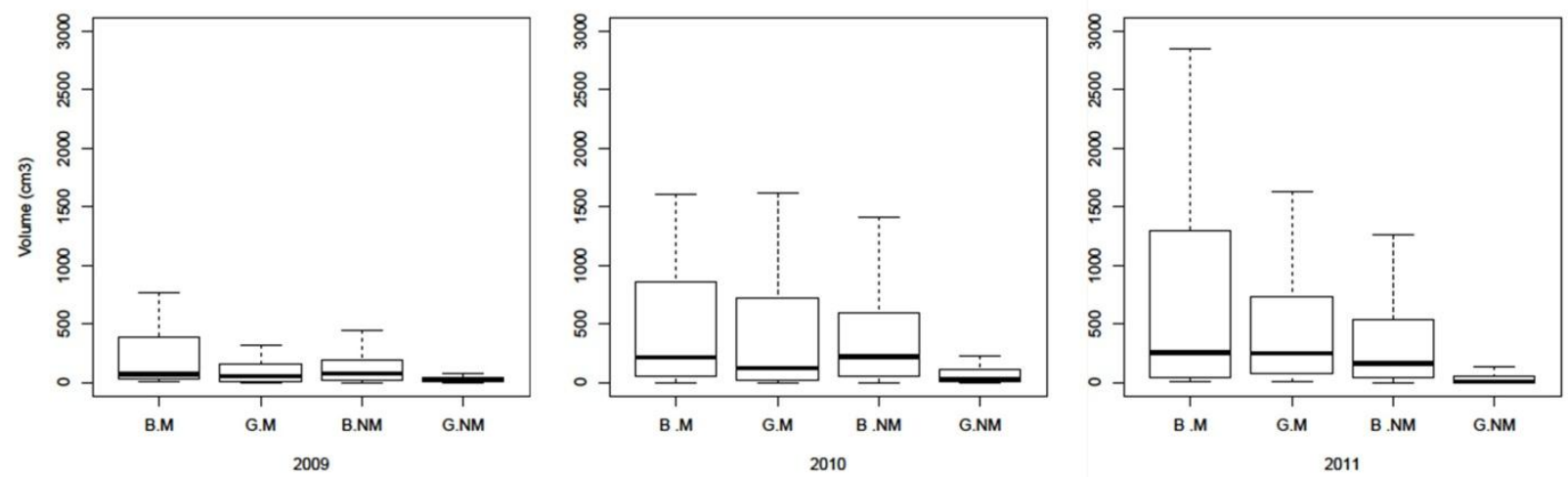

Figure 3-2. 2009-2011 box plots of tree volume indices for areas of brown (B) and gray (G) sandstone with (M) and without (NM) mulch application at the Birch River Operation in Webster County, WV. 
Table 3-5. Mean volume index for eleven species of trees after four growing seasons in eight soil treatment combinations at the Birch River Operation in Webster County, WV*.

\begin{tabular}{|c|c|c|c|c|c|c|c|c|c|}
\hline \multirow[b]{2}{*}{ Year } & \multicolumn{8}{|c|}{ Treatment $\dagger$} & \multirow[b]{2}{*}{ Ave } \\
\hline & B & BH & $\mathbf{B M}$ & BMH & $\mathbf{G}$ & GH & GM & GMH & \\
\hline Volume Index & & 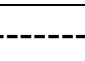 & --- & -------. & $m^{3}-$ & 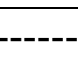 & - & ----- & \\
\hline 2008 & 43 & 50 & 36 & 27 & 27 & 17 & 48 & 14 & 40 \\
\hline 2009 & 218 & 293 & 299 & 507 & 30 & 40 & 217 & 63 & 210 \\
\hline 2010 & 582 & 712 & 1047 & 705 & 72 & 50 & 764 & 181 & 545 \\
\hline 2011 & 821 & 664 & 1153 & 804 & 98 & 64 & 729 & 424 & 621 \\
\hline Survival 2011 & 78 & 85 & 85 & 60 & 84 & 79 & 96 & 100 & 84 \\
\hline
\end{tabular}

$\dagger$ See table 3-1 for treatment descriptions.

*2008 and 2009 tree volume index data from DeLong (2010).

We found no strong empirical support for any of our pre-selected models for survival. Our results indicated no treatment strongly influenced tree survival. The independent model, I, ranked highest of the models at 0.31 (Table 3-6), but it was not much higher than other models (0.21 to 0.13 ). Mean survival ranged from 60 to $100 \%$ (Table 3-5).

Table 3-6. Model ranking using AIC for survival of trees planted at the Birch River Operation in Webster County, WV.

\begin{tabular}{|c|c|c|c|c|c|c|}
\hline Model & $\mathbf{K}$ & AICc & $\triangle \mathrm{AICc}$ & AICcWt & Cum.Wt & $\mathbf{L L}$ \\
\hline I & 2 & 323.99 & 0 & 0.31 & 0.31 & -1824.41 \\
\hline $\mathrm{SS}$ & 3 & 324.16 & 0.76 & 0.21 & 0.52 & -1821.72 \\
\hline $\mathrm{H}$ & 3 & 325.9 & 1.25 & 0.16 & 0.68 & -1824.02 \\
\hline M & 3 & 326.01 & 1.76 & 0.13 & 0.81 & -1821.19 \\
\hline $\mathrm{SS} * \mathrm{M}$ & 4 & 326.29 & 1.96 & 0.12 & 0.93 & -1824.38 \\
\hline $\mathrm{SS} * \mathrm{H}$ & 4 & 326.42 & 2.83 & 0.07 & 1 & -1821.72 \\
\hline
\end{tabular}

\subsubsection{Soil}

For this paper we focused on 2011 soil data but we will refer back to previous year's data when discussing general trends in the soil data. 
No variables were correlated more than $r>0.90$; therefore all measured properties were used in the PCA and AIC analysis. PCA revealed that $\mathrm{Al}, \mathrm{Fe}, \mathrm{P}, \mathrm{Zn}$ and percent fines all loaded strongly in the negative direction, while $\mathrm{Ca}, \mathrm{pH}$ and $\mathrm{EC}$ loaded strongly in the positive direction on principle component (PC) 1 (Table 3-7 and Figure 3-3). Mn and K loaded strongly on PC2 in the positive direction and $\mathrm{Mg}$ loaded strongly on PC2 in the negative direction.

Examination of the PC1:PC2 biplot for 2011 soil data (Figure 3-3) illustrated grouping of soils within treatments having similar properties. All points on the right side of the plot were soils from mulch treatment. Regardless of sandstone type, these soil samples on the right side of the plot tended to have higher $\mathrm{pH}, \mathrm{EC}$ and higher concentrations of $\mathrm{Ca}$ (Tables 3-9 and 3-10). Soil properties of non-mulched treatments from both brown and gray sandstone areas were found on the left side of the plot. Brown sandstone and gray sandstone soil samples did not separate well from one another on the PC1:PC2 biplot. Interestingly, biplots from previous years showed that over time soils from the various treatments became less grouped (Figure 3-4). From 2009 to 2011, soil samples with mulch, regardless of sandstone type, always appeared to group on the side of the biplot where $\mathrm{Ca}, \mathrm{pH}$ and EC loaded the strongest. In 2009 to 2010, samples without mulch appeared on the opposite side of the biplot where Al, Fe, P, Zn, and percent fines loaded the strongest. During these years, the soils also broke out into sandstone type. 
Table 3-7. PCA results for first 3 PCs of 2011 soil properties sampled at the Birch River Operation in Webster County, WV.

\begin{tabular}{lccc}
\hline Variables & PC1 & PC2 & PC3 \\
\hline Eigenvalue & 5.88 & 2.77 & 1.44 \\
\% Variation & 0.49 & 0.23 & 0.12 \\
\% Cumulative variation & 0.49 & 0.72 & 0.84 \\
$\mathrm{Al}$ & 0.87 & 0.21 & 0.14 \\
$\mathrm{Fe}$ & 0.89 & 0.21 & 0.31 \\
$\mathrm{Mn}$ & 0.03 & 0.92 & 0.18 \\
$\mathrm{Mg}$ & 0.37 & 0.87 & 0.18 \\
$\mathrm{Ca}$ & 0.89 & 0.27 & 0.00 \\
$\mathrm{~K}$ & 0.16 & 0.81 & 0.33 \\
$\mathrm{P}$ & 0.63 & 0.41 & 0.53 \\
$\mathrm{Zn}$ & 0.80 & 0.33 & 0.22 \\
$\mathrm{pH}$ & 0.69 & 0.19 & 0.62 \\
$\mathrm{EC}$ & 0.92 & 0.13 & 0.05 \\
\% Fines & 0.60 & 0.03 & 0.55 \\
\hline
\end{tabular}

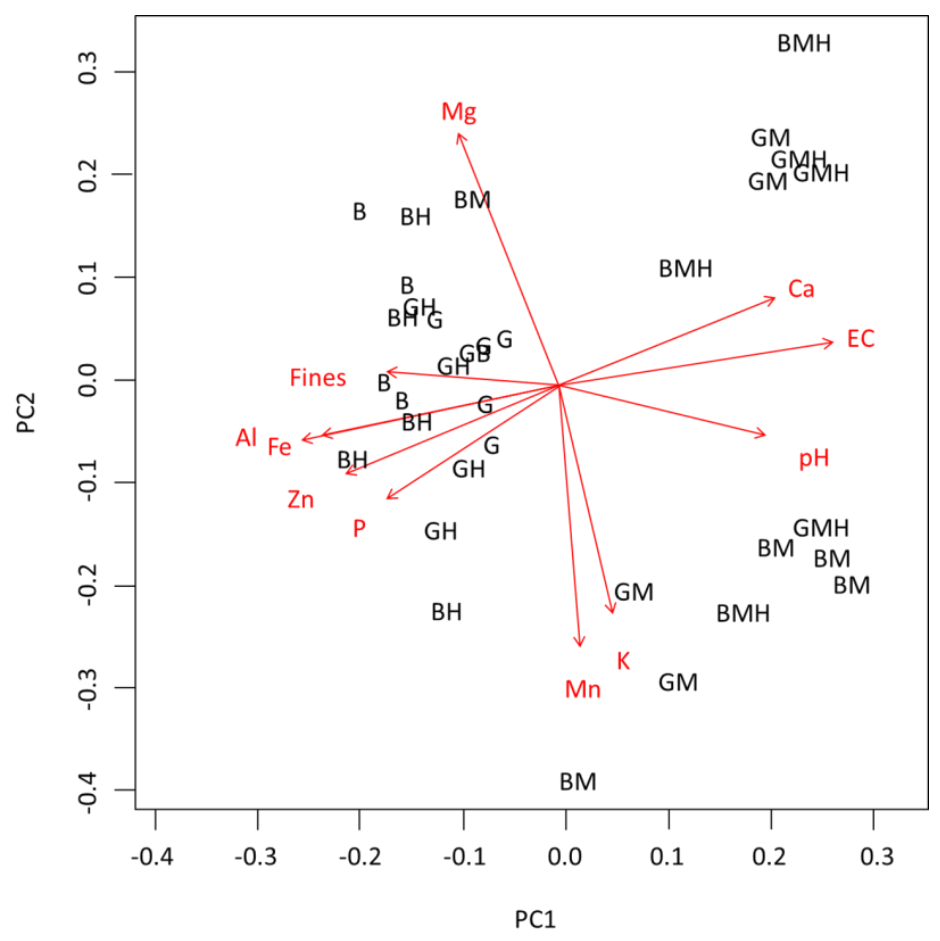

Figure 3-3. PC1:PC2 biplot of 2011 soil properties sampled at the Birch River Operation in Webster County, WV. 


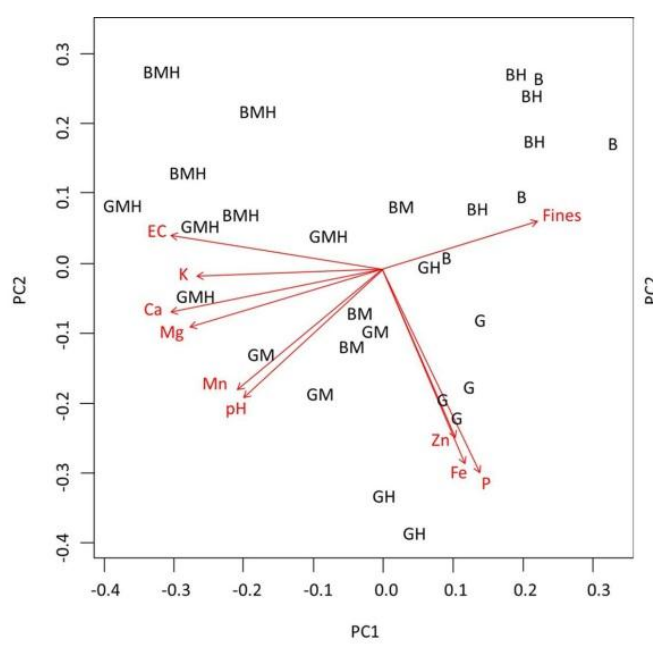

2008

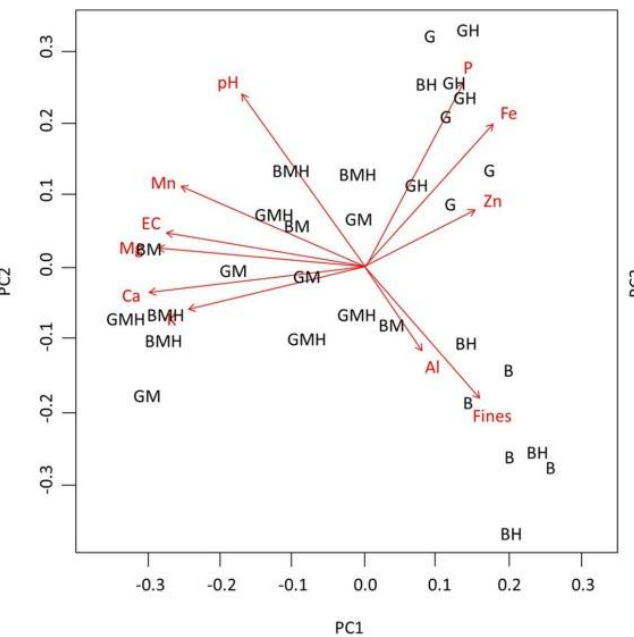

2009

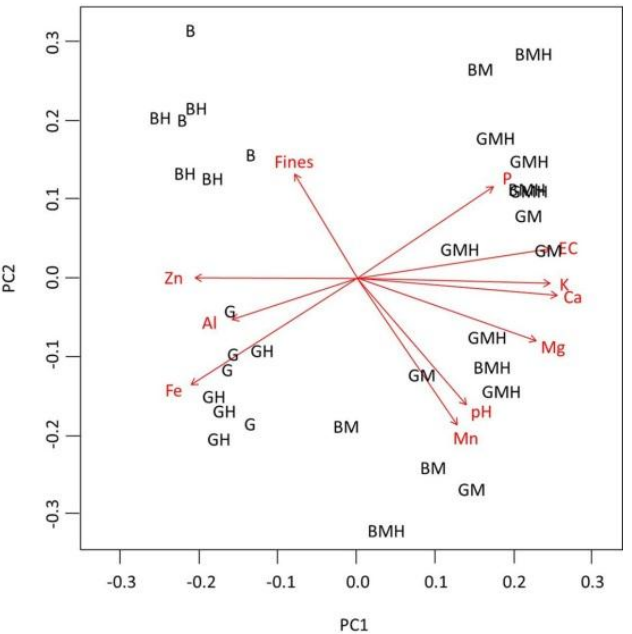

2010

Figure 3-4. PC1:PC2 biplots of 2008 to 2010 soil properties sampled at the Birch River Operation in Webster County, WV.

Interaction between sandstone type and mulch had the strongest influence on soil properties loading on PC1 (Table 3-8) with an AICc weight of 0.81. Mulch alone also had an influence on soil properties of $\mathrm{PC} 1(0.19)$ but not as strong as the interaction with sandstone. AICc weights for all other models were 0 , indicating that hydroseed, hydroseed and sandstone interaction and sandstone type alone had little influence on soil properties loading strongly on PC1. Box plots of $\mathrm{pH}, \mathrm{EC}$ and $\mathrm{Ca}$ concentration indicated that areas with mulch, regardless of sandstone type, had higher mean values than those areas without mulch (Figures 3-5 and 3-6). Brown sandstone exhibited lower $\mathrm{pH}$ values than gray sandstone or mulch treatments, with means ranging from 5.1 to 5.4 (Table 3-9). EC and Ca concentrations in mulched areas also had a larger range of values compared to non-mulched areas (Figures 3-5 and 3-6). Trends for percent fines were less clear, but according to the box plot in Figure 3-5, it appeared that brown sandstone without mulch had the highest mean percent fines at 47\% (Table 3-9). Gray sandstone alone and treatments with mulch had lower percent fines ranging from $34 \%$ to $43 \%$. 
Table 3-8. Model ranking using AIC for PC soil analyses with treatments at the Birch River Operation in Webster County, WV.

\begin{tabular}{llllllll}
\hline PC & Model & K & AICc & DAICc & AICcWt & Cum.Wt & LL \\
\hline PC1 & SS*M & 4 & 110.08 & 0 & 0.81 & 0.81 & -50.4 \\
& M & 3 & 113.01 & 2.93 & 0.19 & 1 & -53.13 \\
& I & 2 & 169.26 & 59.18 & 0 & 1 & -82.45 \\
& SS & 3 & 170.01 & 59.93 & 0 & 1 & -81.63 \\
& H & 3 & 171.64 & 61.55 & 0 & 1 & -82.44 \\
& SS*H & 4 & 172.54 & 62.46 & 0 & 1 & -81.63 \\
PC2 & I & 2 & 142.31 & 0 & 0.45 & 0.45 & -68.97 \\
& SS & 3 & 144.39 & 2.08 & 0.16 & 0.61 & -68.82 \\
& H & 3 & 144.54 & 2.23 & 0.15 & 0.76 & -68.89 \\
& M & 3 & 144.63 & 2.32 & 0.14 & 0.9 & -68.94 \\
& SS*H & 4 & 146.77 & 4.46 & 0.05 & 0.95 & -68.74 \\
& SS*M & 4 & 146.85 & 4.54 & 0.05 & 1 & -68.78 \\
\hline
\end{tabular}

Table 3-9. 2008-2011 soil properties in eight soil treatment combinations at the Birch River Operation in Webster County, WV.

\begin{tabular}{|c|c|c|c|c|c|c|c|c|}
\hline \multirow[b]{2}{*}{ Properties } & \multicolumn{8}{|c|}{ Treatments $\dagger$} \\
\hline & $\mathbf{B}$ & BH & BM & BMH & $\mathbf{G}$ & GH & GM & GMH \\
\hline $\mathrm{pH}$ & \multicolumn{8}{|c|}{------------------------------------ su ------------------------------- } \\
\hline 2008 & 4.7 & 4.8 & 7.1 & 8.1 & 7.9 & 7.4 & 7.0 & 6.9 \\
\hline 2009 & 4.8 & 5.4 & 7.5 & 7.8 & 7.8 & 7.8 & 7.5 & 7.0 \\
\hline 2010 & 5.0 & 5.3 & 7.6 & 6.7 & 7.4 & 7.1 & 7.6 & 7.6 \\
\hline 2011 & 5.1 & 5.4 & 7.7 & 7.7 & 7.5 & 7.3 & 7.7 & 7.7 \\
\hline Electrical conductivity & \multicolumn{8}{|c|}{ 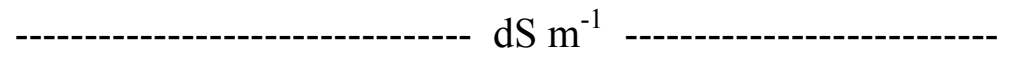 } \\
\hline 2008 & 0.12 & 0.06 & 0.28 & 0.39 & 0.12 & 0.12 & 0.28 & 0.40 \\
\hline 2009 & 0.05 & 0.07 & 0.30 & 0.30 & 0.08 & 0.11 & 0.33 & 0.29 \\
\hline 2010 & 0.08 & 0.08 & 0.42 & 0.35 & 0.09 & 0.16 & 0.53 & 0.49 \\
\hline 2011 & 0.04 & 0.04 & 0.38 & 0.34 & 0.05 & 0.04 & 0.35 & 0.48 \\
\hline Fines & \multicolumn{8}{|c|}{------------------------------------- \% } \\
\hline 2008 & 57 & 47 & 24 & 26 & 41 & 33 & 34 & 32 \\
\hline 2009 & 52 & 49 & 37 & 41 & 40 & 36 & 42 & 35 \\
\hline 2010 & 38 & 41 & 31 & 33 & 25 & 26 & 24 & 24 \\
\hline 2011 & 47 & 47 & 34 & 37 & 37 & 43 & 38 & 36 \\
\hline
\end{tabular}

$\dagger$ See table 3-1 for treatment descriptions

*2008 and 2009 soil data from DeLong (2010). 

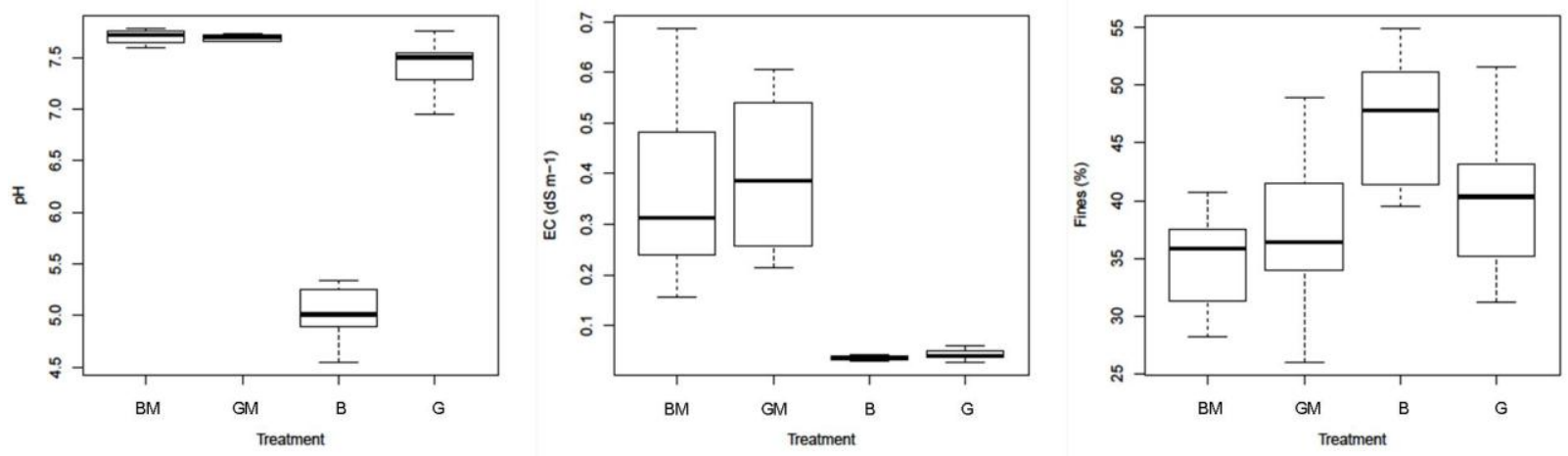

Figure 3-5. 2011 box plots of $\mathrm{pH}, \mathrm{EC}$, and percentage fines from samples taken from areas of brown (B) and gray (G) sandstone with mulch (M) and without mulch application at the Birch River Operation in Webster County, WV.

In general, $\mathrm{Al}, \mathrm{Fe}, \mathrm{P}$, and $\mathrm{Zn}$ concentrations were elevated in treatments without mulch. $\mathrm{Al}$ and $\mathrm{Zn}$ were typically highest in brown sandstone treatments without mulch (Figure 3-6). Mean Al concentrations in brown sandstone treatments without mulch ranged from 268 to 417 $\mathrm{mg} \mathrm{kg}^{-1}$ (Table 3-10). Fe and $\mathrm{P}$ concentrations were highest in gray sandstone treatments without mulch. Mean Fe concentrations in gray sandstone treatments without mulch ranged from 184 to $255 \mathrm{mg} \mathrm{kg}^{-1}$ (Table 3-10) and P concentrations ranged from 46 to $61 \mathrm{mg} \mathrm{kg}^{-1}$ with the lowest soil P concentrations in brown and gray, mulched, hydroseeded plots.

Returning to AIC analysis, no treatment appeared to have an influence on soil properties loading strongly on PC2. The model fitting all data to an intercept regardless of treatment ranked the highest with an AICc weight nearly three times more than the weight of the next three ranking models: sandstone type, hydroseed, and mulch alone. Both interaction models ranked the lowest with an AICc weight of 0.05 (Table 3-8). These results were supported by both the mean values for $\mathrm{Mg}, \mathrm{Mn}$, and $\mathrm{K}$ found in Table 3-10 and the boxplots for the same elements in Figure 3-6. There was no distinct pattern among treatments for these elements. In addition they 
appeared to have large over lapping ranges of values among treatments of brown and gray sandstone with and without mulch. 
Table 3-10. 2008-2011 soil properties in eight soil treatment combinations at the Birch River Operation in Webster County, WV*.

\begin{tabular}{|c|c|c|c|c|c|c|c|c|}
\hline \multirow[b]{2}{*}{ Elements } & \multicolumn{8}{|c|}{ Treatments $\dagger$} \\
\hline & B & BH & BM & BMH & $\mathbf{G}$ & GH & GM & GMH \\
\hline $\mathrm{Mg}$ & \multicolumn{8}{|c|}{ - } \\
\hline 2008 & 9.0 & 3.0 & 8.8 & 17 & 7.1 & 12 & 22 & 29 \\
\hline 2009 & 4.2 & 4.7 & 15 & 15 & 5.7 & 5.7 & 14 & 11 \\
\hline 2010 & 4.1 & 2.7 & 14 & 15 & 4.1 & 4.5 & 12 & 14 \\
\hline 2011 & 4.4 & 4.6 & 10 & 7.7 & 4.2 & 4.4 & 8.6 & 6.3 \\
\hline \multicolumn{9}{|l|}{$\mathrm{K}$} \\
\hline 2008 & 0.78 & 0.88 & 1.1 & 1.7 & 0.86 & 1.1 & 1.2 & 1.7 \\
\hline 2009 & 0.43 & 0.56 & 0.80 & 0.80 & 0.35 & 0.47 & 0.68 & 0.74 \\
\hline 2010 & 0.07 & 0.06 & 0.89 & 0.82 & 0.30 & 0.41 & 0.76 & 0.87 \\
\hline 2011 & 0.44 & 0.45 & 0.71 & 0.34 & 0.31 & 0.34 & 0.36 & 0.37 \\
\hline \multicolumn{9}{|l|}{$\mathrm{Ca}$} \\
\hline 2008 & 6.6 & 2.5 & 30 & 97 & 9.0 & 15 & 68 & 110 \\
\hline 2009 & 4.2 & 0.63 & 113 & 109 & 9.2 & 10 & 124 & 91 \\
\hline 2010 & 3.7 & 3.3 & 70 & 71 & 6.5 & 8.1 & 77 & 74 \\
\hline 2011 & 4.5 & 5.0 & 120 & 71 & 5.4 & 4.1 & 77 & 77 \\
\hline $\mathrm{Al}$ & ----- & & & ----- & $\mathrm{kg}^{-1}$ & & & ----- \\
\hline 2008 & - & - & - & - & - & - & - & - \\
\hline 2009 & 182 & 850 & 238 & 145 & 84 & 83 & 206 & 727 \\
\hline 2010 & 171 & 45 & 96 & 195 & 88 & 100 & - & 200 \\
\hline 2011 & 268 & 417 & 156 & 31 & 73 & 89 & 89 & 5 \\
\hline \multicolumn{9}{|l|}{$\mathrm{Fe}$} \\
\hline 2008 & 384 & 497 & 314 & 37 & 1608 & 3270 & 1034 & 454 \\
\hline 2009 & 89 & 258 & 81 & 142 & 375 & 359 & 65 & 185 \\
\hline 2010 & 65 & 130 & 65 & 84 & 304 & 407 & 17 & 40 \\
\hline 2011 & 116 & 177 & 70 & 12 & 184 & 255 & 20 & 8 \\
\hline \multicolumn{9}{|l|}{$\mathrm{Mn}$} \\
\hline 2008 & 912 & 303 & 899 & 1728 & 716 & 1229 & 2307 & 2980 \\
\hline 2009 & 423 & 482 & 1547 & 1534 & 575 & 573 & 1457 & 1165 \\
\hline 2010 & 493 & 326 & 1710 & 1799 & 495 & 545 & 1406 & 1730 \\
\hline 2011 & 448 & 464 & 1102 & 578 & 428 & 447 & 870 & 640 \\
\hline \multicolumn{9}{|l|}{$\mathrm{P}$} \\
\hline 2008 & 22 & 15 & 32 & 6.7 & 96 & 101 & 38 & 10 \\
\hline 2009 & 16 & 63 & 15 & 32 & 141 & 202 & 21 & 12 \\
\hline 2010 & 15 & 31 & 10 & 12 & 69 & 80 & 11 & 10 \\
\hline 2011 & 17 & 26 & 17 & 4.6 & 61 & 46 & 4.3 & 6.6 \\
\hline \multicolumn{9}{|l|}{$\mathrm{Zn}$} \\
\hline 2008 & 21 & 16 & 33 & 9.2 & 26 & 30 & 29 & 10 \\
\hline
\end{tabular}




\begin{tabular}{lllllllll}
2009 & 23 & 24 & 13 & 15 & 21 & 23 & 17 & 12 \\
2010 & 19 & 11 & 1.4 & 4.9 & 8.6 & 15 & 0.2 & 1.9 \\
2011 & 24 & 23 & 7.9 & 3.4 & 11.63 & 18 & 4.0 & 0.6 \\
\hline
\end{tabular}

$\uparrow$ See table 3-1 for treatment descriptions

*2008 and 2009 soil data from DeLong (2010).
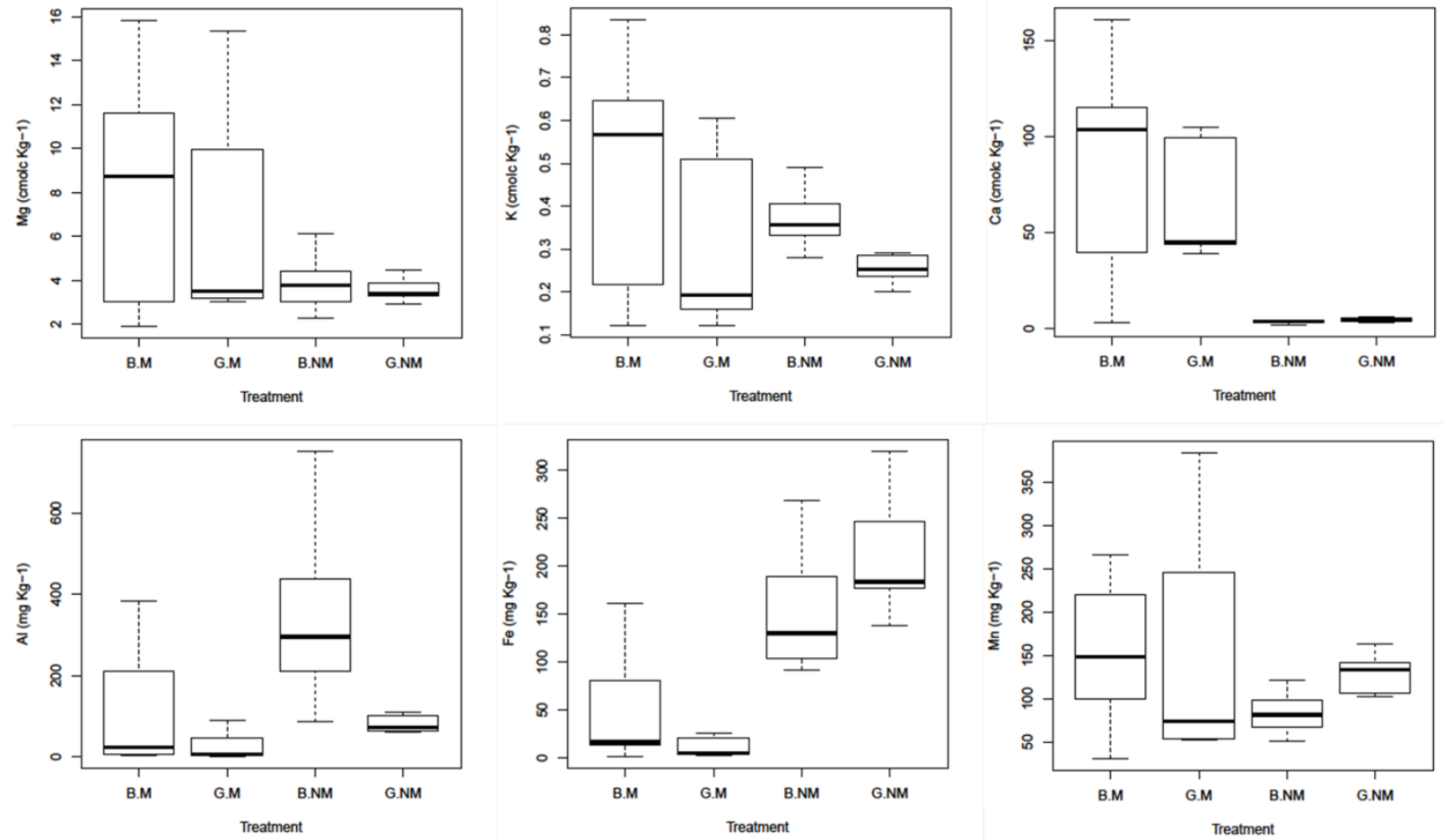

Figure 3-6. Box plots of extractable elements from samples taken in 2011 from areas of brown (B) and gray (G) sandstone with mulch (M) and without mulch application at the Birch River Operation in Webster County, WV.
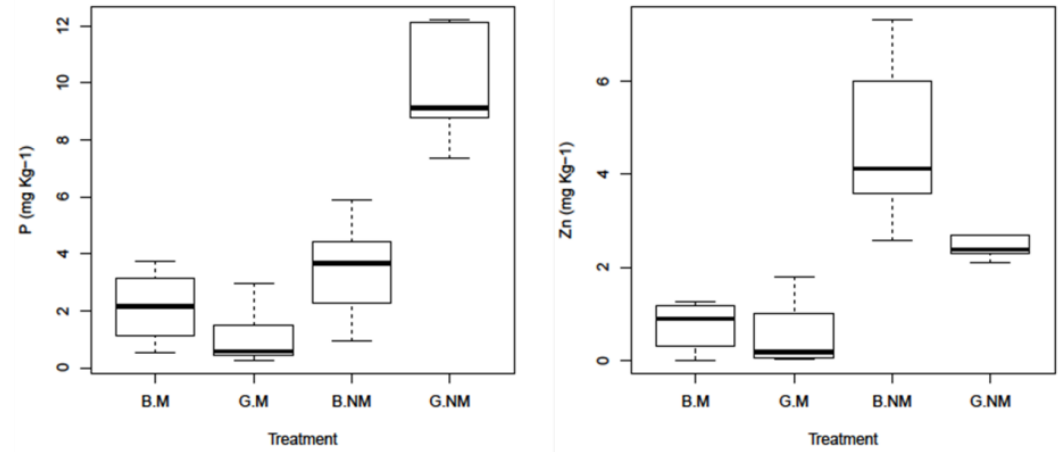

\subsection{Discussion}

3.4.1. Trees 
In this study, the interaction between sandstone type and mulch was the most influential treatments on tree growth in 2009 to 2011. Sandstone type and mulch alone had little prediction ability on tree volume index, but large disparities were evident between brown sandstone and gray sandstone without mulch. Gray sandstone without mulch continually under-performed all treatments (except for tree survival) and exhibited the poorest tree volume index. This trend is commonly seen in studies comparing the two mediums. Results from studies by Emerson et al. (2009) and Angel et al. (2008) found that trees in brown sandstone had greater volume index than trees in gray sandstone. Sandstone types amended with mulch exhibited a larger range of tree volume indices and generally a higher mean tree volume index. The sandstone types may become more important to tree growth as trees become more deeply rooted in the mineral soil. Although not investigated, it is speculated that the mulch was the primary rooting medium for these small trees and not the sandstone type beneath the mulch layer. As mulch decomposes and becomes more incorporated into the mineral soil, the current trend may continue. Differences between mulch and non-mulch areas could also be due to differences in micro climate. Bark mulches have the ability to retain water and heat, preventing extreme conditions that may occur in the bare mineral soil.

Differences in growth may be an artifact of uneven species distribution, rather than a product of treatment conditions. Eleven different tree species were planted across the site, each with different seedling sizes and early growth characteristics. Logistics of planting did not allow for random planting resulting in the same tree groupings of the same species and even species distribution over the entire plot. Species were not represented in all treatments or were over represented in others (Table 3-11). Due to differences in original seedling size and growth habits, it is possible that mean volume indices were inflated or underinflated based on species 
distribution. Looking at individual species may have been more appropriate but this was not possible in this study because of some tree species not being represented in all treatments, the small sample sizes in each treatment, and lack of replication.

Table 3-11. Number and distribution of eleven species of trees after four growing seasons in eight soil treatment combinations at the Birch River Operation in Webster County, WV.

\begin{tabular}{lccccccccc}
\hline & \multicolumn{1}{c}{ Treatment $\dagger$} \\
\cline { 2 - 10 } Species & B & BH & BM & BMH & G & GH & GM & GMH & Total \\
\hline Black cherry & 7 & 15 & 2 & - & 5 & - & 3 & 3 & 35 \\
Black locust & 17 & 88 & 13 & 8 & 8 & 10 & 13 & 6 & 163 \\
Dogwood & -+ & - & - & - & 2 & - & 1 & - & 3 \\
Redbud & 2 & - & 1 & - & 3 & - & 1 & - & 7 \\
Northern red oak & 8 & 17 & 1 & - & 7 & 3 & 5 & 2 & 43 \\
Sugar maple & 16 & 10 & 1 & - & 2 & 3 & 4 & 1 & 37 \\
Sycamore & 4 & 6 & - & 2 & 2 & - & 3 & 2 & 19 \\
Tulip poplar & 4 & 6 & 3 & - & 9 & 3 & 8 & 1 & 34 \\
White ash & 7 & 12 & 2 & 3 & 8 & 2 & 4 & 1 & 39 \\
White oak & 14 & 16 & 2 & 2 & 8 & 3 & 4 & 2 & 51 \\
White Pine & 12 & 10 & 6 & 1 & 8 & 2 & 5 & 2 & 46 \\
Total & 91 & 180 & 31 & 16 & 62 & 26 & 51 & 20 & 477 \\
\hline
\end{tabular}

$\uparrow$ See table 3-1 for treatment descriptions

$\$$ Indicates no individuals were present in treatment

The ranking and weight of models including hydroseed application indicated that a seeding rate of $32 \mathrm{~kg} \mathrm{ha}^{-1}$ did not constrain tree growth. No effect of fertilization or hydroseeding on tree growth was observed five years after reclamation.

Tree survival was not affected by treatments. While slightly lower survival rates were observed in non-amended gray sandstone as opposed to gray sandstone with amendments, there was no strong evidence that sandstone type influenced survival. Visual observations in the field indicated that the quality of trees in gray sandstone was lower than in brown sandstone, yet they were persisting. Emerson et al. (2009) and Angel et al. (2008) similarly found no significant 
differences in survival between the two sandstone types. Trees in all treatments in our study showed signs of wildlife browsing and the impact of this was not addressed in our analyses.

\subsubsection{Soil}

The $\mathrm{pH}$ for five of the eight treatment combinations fluctuated over the four years but appeared to have slightly increased from 2008 to 2011 (Table 3-9). Brown sandstone with mulch and hydroseed, and both gray sandstone treatments without mulch have slightly lower values in 2011 compared to 2008, but again had shown fluctuation over four years. Decreasing pH was observed in similar reclaimed mine soils of southwest Virginia in a study by Haering et al. (2004). The $\mathrm{pH}$ values decreased over the first three years of the study then rebounded to near initial levels or remained the same for the duration of the study. The increase in $\mathrm{pH}$ was attributed to the exposure and subsequent weathering of carbonates. Emerson et al. (2009) also reported fluctuations of $\mathrm{pH}$ values over a three year study. The overall $\mathrm{pH}$ values of the two nonmulched sandstone types were similar to those found in the same study by Emerson et al. (2009) with values for brown sandstone ranging from 4.5 to 6.1 and from 8.1 to 8.2 for gray sandstone. Showalter et al. (2010) reported a pH of 5.53 for brown sandstone and 8.38 for gray sandstone. Gray sandstone values were slightly higher in these studies but comparable to those found in this study. The elevated $\mathrm{pH}$ of all mulch treatments regardless of sandstone type can be attributed to the presence of limestone gravel in the bark mulch. Limestone was added as aggregate on log landings and incorporated into the mulch during machinery operation at the sawmill.

The presence of limestone in the mulch also accounted for the elevated EC in mineral soil below the mulch. EC values for mulch treatments were nine to 12 times higher than non-mulch treatments. All values were still less than $0.5 \mathrm{dS} \mathrm{m}^{-1}$ and were not high enough to negatively 
impact tree growth. According to McFee et al. (1981), EC values of $1.0 \mathrm{dS} \mathrm{m}^{-1}$ and greater are potentially detrimental to tree growth on reclaimed mine lands. No differences in EC for sandstone type were observed.

The elevated levels of $\mathrm{Ca}$ and $\mathrm{Mg}$ in mulched areas were also caused by limestone in the bark. After four years, little difference was observed in Ca concentrations among non-mulched sandstone treatments. In previous years, gray sandstone exhibited slightly elevated levels, and an overall decrease in Ca concentration has occurred in both sandstones. In other studies, elevated levels of $\mathrm{Ca}$ in gray sandstone were reported and were likely a result of carbonate weathering (Haering et al., 2004)

Concentrations of $\mathrm{Al}, \mathrm{Fe}, \mathrm{P}$, and $\mathrm{Zn}$ over time and within treatment combinations fluctuated and did not show clear trends. Overall, concentrations of these elements were lower on mulched areas. The reduction of $\mathrm{Al}, \mathrm{Fe}, \mathrm{P}$ and $\mathrm{Zn}$ in mulched areas could be the result of metal complexes with organic matter. Both P and Zn have a high affinity for organic matter in soils (Havlin et al., 2005). Higher levels of $\mathrm{Al}$ observed in brown sandstone was expected since weathered materials tend to have more $\mathrm{Al}$ and $\mathrm{Fe}$ oxides (Haering et al., 1993). On the contrary, the gray sandstone had higher concentrations of Fe than the brown and has shown this trend since the beginning of the study. The higher levels of Fe in the non-mulched areas could result in Fe-P complexes that would prevent future availability of $\mathrm{P}$ for plant uptake (Haering et al., 2004). Concentrations of $\mathrm{P}$ in gray sandstone remained higher than those found in brown sandstone over the four years of the study. However, concentrations of P in gray sandstone appeared to decrease more rapidly over time. Phosphorus found in gray sandstone was not necessarily plant available (Skousen and 
Emerson, 2010). In addition to Fe-P complexes at a $\mathrm{pH}$ above 7, $\mathrm{P}$ has the tendency to bind to $\mathrm{Ca}$ reducing the availability to plants (Klock et al., 1984).

Five years after reclamation, any effects of hydroseeding, including fertilizer added with the seed, on soil chemical properties have been erased with time and by natural processes.

\subsection{Conclusions}

In this study, sandstone type and application of bark mulch had large effects on tree volume index. Survival was not influenced by any sandstone type, mulch or hydroseeding treatment. Four years after reclamation, hydroseeding at a rate of $32 \mathrm{~kg} \mathrm{ha}^{-1}$ had no effect on tree volume index or soil properties. Interaction between sandstone type and mulch was most influential on tree volume index and soil chemical properties. Sandstone type and mulch strongly influenced soil chemical properties. Mulch application was capable of altering the inherent chemical properties of sandstone overburden materials and could potentially create more suitable medium for tree growth. 


\subsection{References}

Angel, P., J. Burger, V. Davis, C. Barton, M. Bower, S. Eggerud, and P. Rothman. 2009. The forestry reclamation approach and the measure of its success in Appalachia. p. 18-36. In: Proceedings, 26thAnnual Meetings of the American Society of Mining and Reclamation. Billings, MT.

Angel, P.N., D.H. Graves, C. Barton, R. C. Warner, P.W. Conrad, R.J. Sweigard, and C. Agouridis. 2006. Surface mine reforestation research: evaluation of tree response to low compaction reclamation techniques. In: Proc. of International Conference on Acid Rock Drainage, American Society for Mining and Reclamation, March 26-30, 2006, St. Louis MO.

Anderson, J.D., L.J. Ingram, P.D. Stahl. 2008. Influence of reclamation management practices on microbial biomass carbon and soil carbon accumulation in semiarid mined lands of Wyoming. App. Soil Ecol. 40:387-397.

Burger, J., V. Davis, C. Zipper, J. Franklin, J. Skousen, C. Barton, and P. Angel. 2009. Treecompatible ground covers for reforestation and erosion control. Forest Reclamation Advisory No. 6, July 2009, Appalachian Regional Reforestation Initiative. http://arri.osmre.gov/

Burger, J.A., and C.E. Zipper. 2002. How to restore forests on surface mined lands in Virginia. Virginia Cooperative Extension Publication 460-123.

Burger, J., D. Graves, P. Angel, V. Davis, and C. Zipper. 2005. The forestry reclamation approach. Office of Surface Mining. Washington, D.C.

Burnham, K.P., and D.R. Anderson. 2002. Model selection and multimodel inference: A practical information-theoretic approach, $2^{\text {nd }}$ Ed., Springer-Verlag, New York, NY.

Chaney, W.R., P.E. Pope, and W.R. Byrnes. 1995. Tree survival and growth on land reclaimed in accordance with Public Law 95-87. J. Environ. Qual. 24:630-634.

DeLong, C. 2010. Evaluation of reforestation efforts on two reclaimed surface mines in West Virginia. M.S. Thesis, West Virginia University, Morgantown, WV.

Emerson, P., J. Skousen, and P. Ziemkiewicz. 2009. Survival and growth of hardwoods in brown veresus gray sandstone on a surface mine in West Virginia. J. Environ. Qual. 38:18211829

Falk, B. 1997. Opportunities for the woodwaste resource. Forest Products Journal 47: 17-22.

Havlin, J.L, J.D.Beaton, S.L.Tisdale, and W.L.Nelson. 2005. Soil fertility and fertilizers. Pearson Education, Inc. Upper Saddle River, New Jersey. p515 
Haering, K.C., W.L. Daniels, and J.M. Galbraith. 2004. Appalachian mine soil morphology and properties: effects of weathering and mining method. Soil Sci. Soc. Am. J. 68:1315-1325.

Haering, K.C., W.L. Daniels, and J.A. Roberts. 1993. Changes in mine soil properties resulting from overburden weathering. J. Environ. Qual. 22:194-200.

Holl, K.D., C.E. Zipper, and J.A. Burger. 2001. Recovery of native plant communities after mining. Powell River Project Series. Virginia Cooperative Extension. Pub. \#460-140.

Insam, H. and K.H. Domsch. 1988. Relationship between soils organic carbon and microbial biomass on chronosequences of reclamation sites. Microb. Ecol. 15:177-188

King, J. and J. Skousen. 2003. Tree survival on a mountaintop surface mine in West Virginia. p. 563-574. In: R.I. Barnhisel (ed.) Proc. of National Meeting of the American Society of Mining and Reclamation and $9^{\text {th }}$ Billing Land Reclamation Symposium, Billings, MT. June 3-6, 2006.

Klock, G.O., R.G. Cline, and D.N. Swanston. 1984. Geology and Soils. p. 65-96. In. K.F. Wenger (ed.) Forestry Handbook. Vol. 2.

McFee, W.W., W.R. Byrnes, J.G. Stockton. 1981. Characteristics of coal mine overburden important to plant growth. J. Environ. Qual. 10:300-308.

Norland, M.R. 2000. Use of mulches and soil stabilizers for land reclamation. p. 645-666. In: Reclamation of Drastically Disturbed Lands. (eds R.I. Barnhisel, R.G. Darmody, and W.I. Daniels). American Society of Agronomy, Madison, WI.

R Development Core Team. 2011. R: A language and environment for statistical computing, reference index version 2.13.0. R Foundation for Statistical Computing, Vienna, Austria. ISBN 3-90051-08-9, URL http://www.R-project.org.

Ringe, J.M., D.H. Graves, and J.W. Stringer. 1988. Economics aspects of sawmill residue use for tree seedling establishment on surface mines. Intn. J. Mining and Reclamation and Environment 2:129-133.

Ringe, J.M., D.H. Graves, and J.W. Stringer. 1989. Economics of sawmill residue in the establishment of black locust plantations on surface mines. Intn. J. Mining and Reclamation and Environment 3:201-205.

Rizza, J., J. Franklin, and D. Buckley. 2007. The influence of different ground cover treatments on the growth and survival of tree seedling on remined sites in Eastern Tennessee. p. 663677. In: Proc of 30 years of SMCRA and Beyond. American Society for Mining and Reclamation, Gillette, WY. June 2-7, 2007. 
Showalter, J.M., J.A. Burger, and C.E. Zipper. 2010. Hardwood seedling growth on different mine spoil types without and with topsoil amendment. J. Environ. Qual. 39:483-491.

Skousen, J., and P. Emerson. 2010. Release of nutrients from brown and gray sandstone soil substitutes in southern West Virginia. p. 1135-1143. In: Proceedings, 2010 National Meeting of the American Society of Mining and Reclamation, Pittsburgh, PA, June 5-11, 2010. ASMR, Lexington, KY.

Skousen, J., J. Gorman, E. Pene-Yewtukhiw, J. King, J. Stewart, P. Emerson, and C. DeLong. 2009. Hardwood tree survival in heavy ground cover on reclaimed land in West Virginia: Mowing and ripping effects. J. Environ. Qual. 38:1400-1409.

Skousen, J, P. Ziemkiewicz, and C. Venable. 2006. Tree recruitment and growth on 20-yr-old, unreclaimed surface mined lands in West Virginia. International J. Mining, Reclamation and Environment 20(2):142-154.

Tschaplinski, T., G. Tuskan, G. Michael Gebre, and D. Todd. 1998. Drought resistance of two hybrid Populus clones grown in a large-scale plantation. Tree Physiology 18:653-658.

Torbert, J.L., and J.A. Burger. 2000. Forest land reclamation. p. 371-398. In: Reclamation of Drastically Disturbed Lands. (eds R.I. Barnhisel, R.G. Darmody, and W.L. Daniels). American Society of Agronomy, Madison, WI.

Torbert, J.L., A.R. Tuladhar, J.A. Burger, and J.C. Bell. 1988. Minesoil property effects on the height of 10-year-old white pine. J. Environ. Qual. 17:189-192.

Wick, A.F., W.L. Daniels, W.L. Nash and J.A. Burger. 2010. Soil aggregation, organic matter and microbial dynamics under different amendments after 27 years of mine soil development. p. 1364 - 1386. In: Proc. of Bridging Reclamation, Science and the Community. American Society for Mining and Reclamation, Pittsburgh, PA. June 5-11, 2010. 
4. Soil Biochemical Properties Investigation

\subsection{Literature Review and Objectives}

A diverse microbial population and activity in soils are essential for sustained primary productivity in ecosystems given that they are responsible for the majority of decomposition, and subsequently, nutrient cycling in all terrestrial ecosystems. Yet, microbial populations, activities and health are dependent on vegetation composition and status. Heterotrophic bacteria require organic compounds to carry out metabolic functions. These compounds are mainly introduced to the soil environment in the form of plant litter. In addition, edaphic factors heavily influence the status of both microbial and plant communities. These include temperature, water availability, texture, $\mathrm{pH}$, cation exchange capacity, nutrient levels, and toxic elements (Visser, 1985). Nutrient cycling is of extreme importance in soil fertility. Microorganisms participate in and facilitate nutrient cycling through immobilization and mineralization of organic compounds that have been introduced into the system.

Any drastic land disturbance dramatically alters and disrupts the integrity of the existing plant community, soil resource, and microbial components of an ecosystem. In order to restart and maintain any long or short-term ecosystem function and stability on disturbed areas, all contributing components must be accounted for, measured before disturbance, and then reestablished as quickly as possible during reclamation. The importance of microbial processes on ecosystem stability has generated significant interest in understanding the microbial dynamics in reclaimed mine lands and their link to improving soil quality (Anderson et al., 2008; Chodak et al., 2009; Machulla et al. 2005; Stephens et al., 2001). In addition, researchers are interested in developing methods that can accurately measure microbial activity, community composition and 
function which helps to evaluate reclamation success and the return and re-establishment of ecosystem services (Haney et al., 2008; Ingram et al. 2005; Zipper et al. 2011).

Without reclamation, soil microbial communities are slow to establish (Chodak, 2009) and even with reclamation, microbial activity may take several decades to reach stable conditions found in native soils (Insam and Domsch, 1988; Stephens et al., 2001). Several decades are usually required before a variety of organic matter sources are added and stable compounds are synthesized in mine soils to achieve a high number and diversity of microorganisms. Although some amended mine soils have shown an increase in biological activity through the incorporation of a carbon source (Elkins et al., 1984; Lindermann et al., 1984), Bendfeldt (2001) reported that after 16 years organic amendments yielded no significant difference in Appalachia mine soils with regards to aggregate stability, mineralized $\mathrm{N}$, and soil organic matter (SOM) content. The one difference noted was mine soils amended with municipal sewage sludge had twice the amount of extractable $\mathrm{P}$ after 16 years. This could be potentially important since $\mathrm{P}$, in some situations, becomes the limiting factor in plant growth in these newly created mine soils (Daniels and Zipper, 1988). Other studies (Stephens et al., 2001; Stroo and Jencks, 1982) have reported initial increases in microbial activity following reclamation with the addition of fertilizers and lime and rapid herbaceous plant growth. This increase in activity is seen for the first few years after reclamation but easily decomposable organic matter is rapidly consumed resulting in an overall decline of microbial activity with time if no further introductions of external nutrients and organic matter sources are applied.

A recent greenhouse study by Showalter et al. (2010) compared tree growth in forest topsoil alone to mixtures of topsoil amended with weathered sandstone, unweathered sandstone, and 
unweathered shale, as well as these sandstones and shales alone as growth media. Soil chemical and microbial properties were measured for all treatments and correlations among these properties and growth of ash (Fraxinus americana L.), red oak (Quercus rubra L.), and tulip poplar (Liriodendron tulipifera L.) where explored. It was found that weathered sandstone's (amended with topsoil and not) $\mathrm{pH}$, microbial activity, and water availability were more similar to forest topsoil than any other treatment. In addition, growth of ash and red oak was greater in the amended and unamended brown sandstone mine soil. Overall, topsoil-amended mine soil materials showed greater tree growth and higher microbial activity. The mine soil treatments with topsoil not only aided in restoring soil microorganisms but increased native herbaceous cover by providing a viable seed bank. Coal operators stockpile topsoil until its use in reclamation. Microbial biomass and activity have been shown to decrease with depth and over time in stockpiled topsoil (Visser et al., 1984; Harris et al., 1987). The use of stockpiled soils may have yielded different results in the re-establishment of microorganisms.

Stockpiling soil is a difficult endeavor on mined lands in Appalachia's steep terrain. Other amendment options, such as heavy mulching or sewage sludge applications, can be costly and may not be feasible for large scale reclamation operations. Hydroseeding for introducing lime, fertilizer, and seed is already a common practice in surface mine reclamation. In addition to soil stabilization and conditioning, non-competitive tree compatible vegetation may be useful in conjunction with the Forestry Reclamation Approach (FRA) for the establishment of microbial communities that aid in nutrient cycling.

The objective of this study was to determine the differences in biochemical properties of brown and gray sandstone mine soils and the impact of a hydroseed treatment. 


\subsection{Methods}

\subsubsection{Study Area}

The study site for this investigation was Arch Coal's (formerly International Coal Group) Birch River Operation located near Cowen in Webster County, West Virginia. Details of the site are explained in Chapter 3.

\subsubsection{Sampling}

In May 2011, soil was collected from the top $15 \mathrm{~cm}$ of the mine soil surface and sieved with a $2 \mathrm{~mm}$ screen into a 5-gallon bucket. Three samples were collected and composited from each experimental unit (experimental units are explained in Chapter 3). The shovel, bucket and sieve where cleaned and sterilized with a $10 \%$ ethanol solution between sampling of each experimental unit. Samples were stored in individual plastic bags in a sealed black plastic tub at $4^{\circ} \mathrm{C}$ until analysis took place in July. Before analyses, the needed amount of sample was weighed and allowed to incubate for $24 \mathrm{hrs}$ in the dark at room temperature.

\subsubsection{Soil Moisture}

Soil moisture content was determined by a gravimetric method. Ten grams of field moist soil was weighed into aluminum weighing trays in triplicate for each soil. The weight of the sample was recorded and aluminum trays containing soil were placed in a drying oven set to $100^{\circ} \mathrm{C}$. After 24 hours, the aluminum trays were removed from the oven and allowed to cool for $1 \mathrm{hr}$ at room temperature. Trays and dried soil were weighed. The difference between field moist soil and dry soil samples was recorded as the water weight. Soil moisture content was expressed as the ratio of water weight to dry soil weight of each sample. 


\subsubsection{Soil Organic Carbon (SOC)}

Total carbon was measured with a Leco TruSpec CHN elemental analyzer (LECO Corp. St Joseph, MI). Between 0.09 and 0.11 grams of air-dried soil were weighed into foil cups and combusted at $950^{\circ} \mathrm{C}$. The amount of $\mathrm{CO}_{2}$ evolved was measured with an infrared gas spectrometer and used to determine total combustible carbon.

The contribution of inorganic carbon (carbonates) to total carbon was determined by chemical oxidation of carbonates with a $1 \mathrm{M} \mathrm{HCl}$ solution, a process also used by Insam and Domsch (1988) in a study which investigated SOC and microbial biomass carbon (MBC) on reclaimed mine sites. The procedure as described by Ussiri and Lal (2008) was followed for this

experiment. Two grams of soil were weighed into $50-\mathrm{mL}$ polypropylene centrifuge tubes and reacted with $20 \mathrm{~mL}$ of $1 \mathrm{M} \mathrm{HCl}$ for $30 \mathrm{~min}$ on a reciprocating shaker. Samples were then centrifuged and decanted. This process was repeated twice more for a total of three $\mathrm{HCl}$ washes. After the three washes, samples were placed in a drying oven at $60^{\circ} \mathrm{C}$ for $48 \mathrm{hrs}$. Between 0.09 and 0.11 grams of oven-dried soil were then weighed into foil cups and $\mathrm{C}$ was measured by the Leco CHN analyzer. Inorganic carbon was calculated as the difference between total carbon and carbon evolved from samples reacted with $\mathrm{HCl}$.

Geogenic carbon (coal carbon) was determined by a simple thermal oxidation found to be more effective and less involved than the method described by Ussiri and Lal (2008) and Keene (2010). One gram of dry $\mathrm{HCl}$ washed soil was weighed into ceramic crucibles and placed in a muffle furnace set at $340^{\circ} \mathrm{C}$ for $3 \mathrm{hrs}$. After this heating step, all carbon, except that in the form of geogenic carbon, should have thermally oxidized. Samples were weighed into foil cups, 
combusted, and analyzed for carbon as the above mentioned samples. Soil organic carbon was calculated as the difference between total carbon minus geogenic and carbonate carbon.

\subsubsection{Microbial Biomass Carbon (MBC)}

Soluble carbon and microbial biomass carbon fractions of the soil were determined using the chloroform fumigation extraction method from Brookes and Joergensen (2006). Two sets of 10-g triplicate samples of field moist soil where weighed into $125-\mathrm{mL}$ glass serum bottles. Weight was corrected for moisture. One set of triplicate samples was designated as a control and would not undergo chloroform fumigation. Control samples were extracted with $25 \mathrm{~mL}$ of $0.5 \mathrm{M} \mathrm{K}_{2} \mathrm{SO}_{4}$ on a reciprocating shaker for $60 \mathrm{~min}$. Samples were vacuum filtered through $0.45 \mu \mathrm{m}$ Millipore filters, yielding a soil free extract which was frozen until analyzed using a Sievers 5310C Total Organic Carbon Analyzer (GE Analytical Instruments. Boulder, CO.) for total organic carbon.

For fumigated samples, a 3-mL glass vial with $2 \mathrm{~mL}$ of amylene stabilized chloroform was placed in each serum bottle. Airtight rubber stoppers were used to cap bottles. A vacuum was created by pulling air from each bottle with a vacuum pump. Samples sat for $24 \mathrm{hrs}$ in the dark and then extracted, filtered and analyzed just as control samples were. Microbial biomass carbon was calculated as the difference between the control and fumigated samples divided by an extraction efficiency factor of 0.35 .

\subsubsection{Total Combustible Nitrogen (TCN)}

Total Combustible Nitrogen (TCN) was measured with a Leco TruSpec CHN elemental analyzer (LECO Corp. St Joseph, MI). Between 0.09 and 0.11 grams of air-dried soil were weighed into foil cups and combusted at $950^{\circ} \mathrm{C}$. The evolved nitrogen oxides and nitrogen gas 
from the sample was reduced and measured with an infrared gas spectrometer to determine TCN. Nitrogen contributions from carboniferous material were determined by thermal oxidation just as coal carbon was determined.

\subsubsection{Potentially Mineralizable Nitrogen (PMN)}

Potentially Mineralizable Nitrogen (PMN) was determined using the anaerobic incubation method (Canali and Benedetti, 2006). Non-incubated control triplicate samples were created by weighing 16 grams (on a dry weight basis) of field moist soil and adding $40 \mathrm{~mL}$ of distilled deionized water (DIW) into 250-mL glass Erlenmeyer flasks. Soil was extracted with $40 \mathrm{~mL}$ of $2 \mathrm{M} \mathrm{KCl}$ for $60 \mathrm{~min}$ on a reciprocating shaker. Supernatant was filtered through $0.45 \mu \mathrm{m}$ Millipore filters and frozen until further analysis.

Incubated triplicate samples were created by weighing 16 grams (on a dry weight basis) of field moist soil into 50-mL polypropylene centrifuge tubes. Soil was suspended in $40 \mathrm{~mL}$ of DIW and incubated at $40^{\circ} \mathrm{C}$ for 7 days. Every $24 \mathrm{hrs}$ during the incubation period soil was resuspended in solution. After the incubation period, the soil-water solution was transferred to a 250-mL glass Erlenmeyer flask. Centrifuge tubes were rinsed four times with $2 \mathrm{M} \mathrm{KCl}$ into the same Erlenmeyer flasks. Samples were extracted, filtered and stored as control samples were.

A colorimetric method described by Mulvaney (1996) was used to determine the amount of nitrogen in the form of ammonium $\left(\mathrm{NH}_{4}{ }^{+}\right)$present in the filtered supernatant. The difference between control and incubated samples was calculated and recorded as the PMN.

\subsubsection{Herbaceous Cover}


Herbaceous cover was measured using $1-\mathrm{m}^{2}$ quadrats in five random locations within each experimental unit. Herbaceous cover, litter cover, tree cover, and bare soil/rock were estimated and recorded as a percentage.

\subsubsection{Data Analysis}

Soil moisture, SOC, MBC, TCN, PMN, and herbaceous cover were analyzed by one-way ANOVA by mine soil type and hydroseed application. We used the R language and Environment for Statistical Computing for all the above analyses (R Development Core Team, 2011).

\subsection{Results}

Mine soil type (brown versus gray sandstone) had no significant effect on microbial biomass carbon $(\mathrm{MBC})$ and potentially mineralizable nitrogen (PMN). Mean MBC values were the same in both mine soil types (Table 4-1). Hydroseed application had a significant effect on MBC and PMN (Table 4-1). Mean MBC was over two times higher in the hydroseed treatment with a mass of $16 \mathrm{mg} \mathrm{kg}^{-1}$ compared to $6.8 \mathrm{mg} \mathrm{kg}^{-1}$ in non-hydroseed plots. Mean PMN was greater in the hydroseed treatment (Table 4-1). Herbaceous cover was found to be $30 \%$ on hydroseed treatments, which was significantly higher than non-hydroseed treatments with a cover of 13\% (Table 4-1). Brown sandstone had significantly greater carbon fractions except carbonate carbon than gray sandstone (Table 4.2). Coal fraction nitrogen was significantly higher in brown sandstone. Carbon and nitrogen fractions were not affected by hydroseed treatment. Both MBC:TC and PMN:TCN ratios were higher in the hydroseed treatment (Table 4.3), indicating that more $\mathrm{C}$ and $\mathrm{N}$ in this treatment were in the active fractions and more available for microbes and plants. 
Table 4-1. Mean microbial biomass carbon (MBC), potentially mineralizable nitrogen (PMN) and percent herbaceous cover $(\mathrm{HC})$ for mine soils after five growing seasons at the Birch River Operation in Webster County, WV.

\begin{tabular}{llcrc}
\hline & Treatment & MBC & PMN & Herbaceous Cover \\
\hline Mine Soils & & \multicolumn{2}{c}{--- mg kg --- } & --- \% --- \\
& Brown sandstone & 37 & 0.55 & 20 \\
& Gray sandstone & 37 & 0.45 & 20
\end{tabular}

Hydroseed

$\begin{array}{lccc}\text { Hydroseed } & 44^{*} & 0.85^{* *} & 30^{* *} \\ \text { Non-hydroseed } & 31 & 0.28 & 13\end{array}$

*means for main treatment factors are significantly different at $\mathrm{P}<0.1$

**means for main treatment factors are significantly different at $\mathrm{P}<0.001$

Table 4-2. Carbon and Nitrogen fractions in mine soil samples after five growing seasons at the Birch River Operation in Webster County, WV.

\begin{tabular}{|c|c|c|c|c|c|c|c|c|}
\hline Treatment & & Total C & $\begin{array}{l}\text { Soil } \\
\text { C }\end{array}$ & $\begin{array}{c}\text { Carbonate } \\
\mathrm{C}\end{array}$ & $\begin{array}{c}\text { Coal } \\
\text { C }\end{array}$ & $\begin{array}{c}\text { Total } \\
\mathrm{N} \\
\end{array}$ & $\begin{array}{c}\text { Soil } \\
\mathrm{N}\end{array}$ & $\begin{array}{c}\text { Coal } \\
\mathrm{N} \\
\end{array}$ \\
\hline \multirow[t]{3}{*}{ Mine Soils } & & & & -- & $\mathrm{kg}^{-1}-$ & & & \\
\hline & Brown sandstone & $1833^{* *}$ & $878 * *$ & 272 & $683 * *$ & 90 & 77 & $14^{* *}$ \\
\hline & Gray sandstone & 1427 & 612 & 265 & 549 & 87 & 87 & 0.5 \\
\hline \multicolumn{9}{|l|}{ Hydroseed } \\
\hline & Hydroseed & 1668 & 805 & 232 & 630 & 72 & 66 & 5.8 \\
\hline & Non-hydroseed & 1646 & 732 & 293 & 620 & 100 & 91 & 10 \\
\hline
\end{tabular}

**means within main treatment factors are significantly different at $\mathrm{P}<0.01$ 


\begin{tabular}{|c|c|c|c|}
\hline Treatment & & MBC:TC & PMN:TCN \\
\hline Mine Soils & & \multicolumn{2}{|c|}{-------- \% -------- } \\
\hline \multirow{5}{*}{ Hydroseed } & Brown sandstone & 2.0 & 0.61 \\
\hline & Gary sandstone & 2.5 & 0.52 \\
\hline & & & \\
\hline & Hydroseed & 2.6 & 1.18 \\
\hline & Non-hydroseed & 1.8 & 0.25 \\
\hline
\end{tabular}

\subsection{Discussion}

It was expected that significant differences would be found between the two sandstone mine soils in regards to biochemical properties mainly because of the large differences between the substrates' chemical properties (Chapter 3). A study by Machulla et al. (2005) concluded that parent material was the principle factor effecting $\mathrm{MBC}$ in mine soils of lignite mines in Germany. In their study three types of mine soil were examined before and after reclamation with hay mulch. The lowest MBC was found in an unmulched mine soil similar to the brown sandstone mine soil used in our study. Soil texture of their material was described as a loamy sand with a rock fragment content of $39 \%$, and soil $\mathrm{pH}$ was around 5. Their values for SOC, TCN, and extractable $\mathrm{K}$ and $\mathrm{P}$ were very similar to those of brown and gray sandstone mine soils at the Birch River site. Soil organic carbon in their sandy mine soil ranged from $3800 \mathrm{mg} \mathrm{kg}^{-1}$ in the first $\mathrm{cm}$ from the surface to $500 \mathrm{mg} \mathrm{kg}^{-1} 5$ to $10 \mathrm{~cm}$ below the soil surface. TN ranged from 300 to $0 \mathrm{mg} \mathrm{kg}^{-1}$. After reclamation with mulch, $\mathrm{MBC}$ increased from $9 \mathrm{mg} \mathrm{kg}^{-1}$ to $148 \mathrm{mg} \mathrm{kg}^{-1}$ and remained at a steady concentration for three years following reclamation. MBC in our study 
(ranging from 31 to $44 \mathrm{mg} \mathrm{kg}^{-1}$ ) was three times higher than their unamended mine soils, but considerably lower than their amended mine soils. In the Machulla study and another by Gildon and Rimmer (1993), soil moisture content of the mine soil material was found to be an important property affecting MBC. In our study, no significant differences were found between soil moisture content of the two mine soil types or the hydroseed treatment (data not shown). Although the mine soils at Birch River exhibited the usual differences observed in other studies with mine soils composed of brown and gray sandstone (Angel et al. 2008, Emerson et al. 2009), these mine soils were not dissimilar enough to directly or indirectly produce any differences in MBC. Showalter et al. (2010) similarly found that despite differences in soil chemical and physical properties, $\mathrm{MBC}$ and $\mathrm{PMN}$ in brown and gray sandstone materials were not significantly different. In their study, no differences were measured between MBC in brown and gray sandstone material planted with three types of hardwood trees. For the most part their bare sandstone mine soils were lacking in available N (Schoenholtz et al. 1992). Heterotrophic microflora and fauna are capable of utilizing geogenic carbon in mine soil materials but significant amounts of $\mathrm{N}$ in these materials are generally not available for utilization by plants or microbes (Waschkies and Hüttl, 1999). The PMN:TCN ratio of bare sandstone materials in our study were close to $50 \%$ less than the PMN:TCN ratio found in the hydroseed treatment. This indicates that much less of the $\mathrm{N}$ found in the soil was in the active fraction and was therefore not as available to plants and microbes (Stephens et al., 2001). A regression analysis by Showalter et al. (2010) showed that PMN was highly correlated to tree biomass and therefore the input of litter and nutrients was most likely the limiting factor of growth in mine soils. It could be that limited $\mathrm{N}$ mineralization was responsible for low $\mathrm{MBC}$ in the bare sandstone mine soils of our study. This is further supported by the slightly higher MBC:TC ratio found in the 
hydroseed treatment. Again this higher ratio indicates that more carbon in the hydroseed treatment was in the active fraction (Insam and Domsch, 1988).

Hydroseed treatment did have a significant effect on biochemical properties of the mine soils. Past fertilization, vegetation growth and subsequent vegetation litter provided available $\mathrm{N}$ for microflora and fauna which contributed to the higher MBC found in the hydroseed treatments. A higher PMN:TCN indicated that more of the TCN in hydroseed treatments was available to microbes. Vegetation surveys quantified the differences in herbaceous vegetation between the hydroseed and non-hydroseed treatments. With this being the only difference between the treatments, it was assumed that herbaceous vegetation cover was an influential factor in $\mathrm{MBC}$ and PMN. Mummey et al. (2002) investigated biochemical properties and spatial relationships to plant communities. They discovered that $\mathrm{MBC}, \mathrm{SOM}$, and $\mathrm{N}$ depletions were stratified across the site and concentrated at the base of plant stems. A similar trend could be occurring at the Birch River site. In the bare sandstone treatments, barren areas were found between trees. Our sampling methods did not take this into account, as samples were taken randomly at varying distances from tree bases. We may have diluted our samples by mixing samples near trees with samples further away from the bases of trees thereby resulting in lower MBC and PMN. Had we sampled closer to tree bases, we may have found our MBC and PMN values to be more similar to our hydroseed treatments. In the hydroseeded areas of the plot, a more uniform plant cover was found with less exposed soil. Vegetation that rapidly decomposes and is recycled in mine soils appears to be beneficial for microbial activity. Herbaceous cover may promote a more homogenous soil environment which could promote root expansion by trees and shrubs (Mummey et al., 2002). Other studies on reclamation and biochemical properties have demonstrated the positive impact of mulching and other organic matter additions on biological 
soil properties of reclaimed mine sites (Anderson et al., 2008; Machulla et al., 2005; Showalter et al., 2010).

This microbial study was conducted five years after trees were planted and hydroseeding was performed, and as such provided a snapshot evaluation of reclamation progress at the site. Future studies at this site documenting changes of biochemical properties over time would better assess the nutrient cycling capabilities and progress of reclamation at the site. In this manner, the success of reclamation practices and the return of ecosystem services could be evaluated. Other studies have examined these dynamic biochemical properties over time and demonstrated the development and evolution of microbial populations and diversity, which were used to indicate reclamation success on a site (Akala and Lal, 2001; Anderson et al., 2008; Insam and Domsch, 1988). According to a chronosequence study of reclaimed sites in West Virginia by Stephens et al. (2001), reclaimed mines saw a pulse in microbial activity and biomass in the first ten years after reclamation followed by a steady decline during the following years. This pulse was attributed to the rapid consumption of nutrients provided by fertilizers and the quick turnover by herbaceous vegetation. While PMN and MBC were currently higher in the hydroseed treatment, it is possible that this site was only experiencing a temporary pulse in microbial activity.

Hydroseeding at a rate of $35 \mathrm{~kg} \mathrm{ha}^{-1}$ with non-competitive tree compatible herbaceous vegetation (Table 3-2) and applying $336 \mathrm{~kg} \mathrm{ha}^{-1}$ of 10-20-10 NPK fertilizer had a significant effect on microbial biomass, but less so on tree growth and soil chemical and physical properties. This study showed that hydroseed application was a beneficial practice to enhance microbial development which can restore nutrient cycling abilities to FRA sites. 


\subsection{References}

Anderson, J.D., L.J. Ingram, and P.D. Stahl. 2008. Influence of reclamation management practices on microbial biomass carbon and soil carbon accumulation in semiarid mined lands of Wyoming. App. Soil Ecol. 40:387-397.

Angel, P.N., C.D. Barton, R.C. Warner, C. Agouridis, T. Taylor, and S.L. Hall. 2008. Tree growth, natural regeneration, and hydrologic characteristics of three loose-graded surface mine spoil types in Kentucky. Pp. 28-65. In: Barnhisel RI (ed) Proceedings, 25th Conference of the American Society of Mining and Reclamation, Lexington.

Bendfelt, E.S., J.A. Burger, and W.L. Daniels. 2001. Quality of amended mine soils after sixteen years. Soil Sci. Soc. Am. J. 65:1736-1744.

Brooks, P.C. and R.G. Joergensen. 2006. Microbial biomass measurements by FumigationExtraction. In J. Bloem, D.W. Hopkins, and A. Benedetti (eds.) Biological methods for assessing soil quality. CABI Publishing, Cambridge, MA.

Canali, S. and A. Benedetti. 2006. Soil nitrogen mineralization. In J. Bloem, D.W. Hopkins, and A. Benedetti (eds.) Biological methods for assessing soil quality. CABI Publishing, Cambridge, MA.

Chodak. M., M. Pietrzykowski, and M. Niklinska. 2009. Development of microbial properties in a chronosequence of sandy mine soils. App. Soil Ecol. 41:259-268.

Daniels, W.L., and C.E. Zipper. 1988. Improving coal surface mine reclamation in the Central Appalachian region. p. 139-162. In J. Cairns, Jr. (ed.) Rehabilitating damaged ecosystems. Vol. I. CRC Press, Boca Raton, FL.

Elkins, N.Z, L.W. Parker, E. Aldon, and W.G. Whitford. 1984. Responses of soil biota to organic amendments in stripmine spoils in Northwestern New Mexico. J. Environ. Qual. 13:215219.

Emerson, P., J. Skousen, and P. Ziemkiewicz. 2009. Survival and growth of hardwoods in brown vs gray sandstone on a surface mine in West Virginia. J. Environ. Qual. 38: 18211829.

Gildo, A. and D.L. Rimmer. 1993. Soil respiration on reclaimed coal-mine spoil. Biology and Fertility of Soils 16:41-44.

Haney, R.L., L.R. Hossner, and E.B. Haney. 2008. Soil microbial respiration as a tool to assess post mining reclamation. Internat. J. Mining and Reclamat. Enviro. 22:48-59 
Harris, J.A., and P. Birch. 1987. The effects of topsoil storage during opencast mining operations. J. Sci. Food Agric. 40:220-221.

Ingram, L., G.E. Schuman, P.D. Stahl, and L.K. Spackman. 2005. Microbial respiration and organic carbon indicate nutrient cycling recovery in reclaimed soils. Soil. Sci. Soc. Am. J. 69:1737-1745.

Insam, H., and K.H. Domsch. 1988. Relationship between soils organic carbon and microbial biomass on chronosequences of reclamation sites. Microb. Ecol. 15:177-188

Keene, T. 2010. Switchgrass establishment and growth for biofuels and carbon sequestration on reclaimed mine lands in Appalachia. M.S. Thesis, West Virginia University, Morgantown,WV. http://wvuscholar.wvu.edu:8881//exlibris/dtl/d3 1/apache_media/L2V4bGlicmlzL2R0bC 9kM18xL2FwYWNoZV9tZWRpYS8yMzc5OA==.pdf

Lindemann, W. C., D. L. Lindsey, and P. R. Fresquez. 1984. Amendment of mine spoil to increase the number and activity of microorganisms. Soil Sci. Soc. Am. J. 48:574-578

Machulla, G., M.A. Burns, and K.W. Scow. 2005. Microbial properties of mine spoil materials in the initial stages of soil development. Soil Sci. Soc. Am. J. 69:1069-1077.

Mulvaney, R.L. 1996. Nitrogen-inorganic forms. p. 1146 - 1162. In Sparks, D.L., et al., Methods of Soil Analysis. Part 3, Chemical Methods, Chapter 4. Soil Sci. Soc. Am., Madison, WI.

Mummey, D.L., P.D. Stahl, and J.S. Buyer. 2002. Soil microbiological properties 20 years after surface mine reclamation: spatial analysis of reclaimed and undisturbed sites. Soil Biol. Biochem. 34:1717-1725.

Schoenholtz, S.H., J.A. Burger, and R.E. Kreh. 1992. Fertilizer and organic amendment effects on mine soil properties and revegetation success. Soil Sci. Soc. Am. J. 56:1177-1184.

Showalter, J.M., J.A. Burger, and C.E. Zipper. 2010. Hardwood seedling growth on different mine spoil types without and with topsoil amendment. J. Environ. Qual. 39:483-491.

Stephens, K.M., Sexstone, A.J., Sencindiver, J.C., Skousen, J.G., Thomas, K.A., 2001. Microbial indicators of minesoil quality in southern West Virginia. In: Proceedings of the 16th Annual Meeting on Land Reclamation-A Different Approach, vol. 1, American Society of Mining and Reclamation, pp. 317-325.

Stroo, H.F., and E.M. Jencks. 1982. Enzyme activity and respiration in minesoils. Soil Sci. Soc. Am. J. 46:548-553.

Ussiri, D.N.A., and R. Lal. 2008. Method for determining coal carbon in the reclaimed minesoils contaminated with coal. Soil Sci. Soc. Am. J. 72:231-237. 
Visser, S., J. Fujikawa, C. L. Griffiths, and D. Parkinson. 1984. Effect of topsoil storage on microbial activity, primary production and decomposition potential. Plant and Soil. $82: 41-50$.

Visser, S. 1985. Management of microbial processes in surface mined land in Western Canada. In Tate, R.L. and Klien, D.A., eds. Soil reclamation processes, microbial analysis and applications. New York: Marcel Dekker: 203-241.

Waschkies, C., and R.F. Hüttl. 1999. Microbial degradation of geogenic organic C and N spoils. Plant and Soil. 213:221-230.

Zipper, C., J. Burger, J. Skousen, P. Angel, C. Barton, V. Davis, and J. Franklin. 2011. Restoring forests and associated ecosystem services on Appalachian coal surface mines. Environ. Management 47: 751-765. 